U NIVERSITY OF COPENHAGEN

\title{
Sikkerhed i en digital tidsalder?
}

Byrjalsen, Niels; Kristensen, Kristian Søby

Published in:

Udenrigs

Publication date:

2017

Document version

Også kaldet Forlagets PDF

Citation for published version (APA):

Byrjalsen, N., \& Kristensen, K. S. (2017). Sikkerhed i en digital tidsalder? Udenrigs, December 2017, $32-37$. 
DECEMBER 2017 · TIDSSKRIFTET PÅ DANSK OM UDENRIGSPOLITIK OG INTERNATIONALE FORHOLD

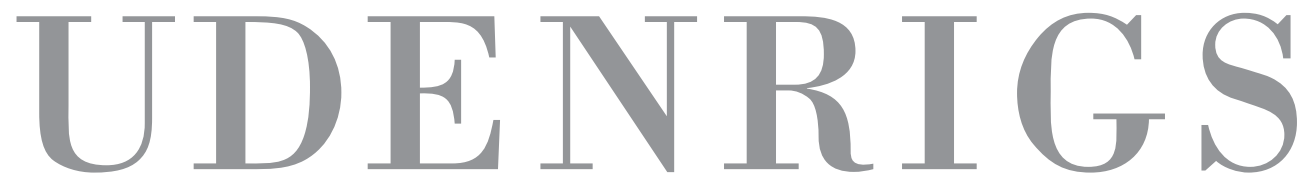

\section{Tema: Dansk sikkerhed år 2018}

Merkels sidste sejr

Anmeldelser: Nedrustningsbegrebets lange vej gennem folkeretten

FOTO: Anders Fridberg

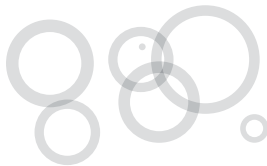

DET UDENRIGSPOLITISKE SELSKAB

THE DANISH FOREIGN POLICY SOCIETY 
INDHOLD

Fra redaktionen

Klumme: Rusland på afveje

\section{TEMA}

Danmark: et land under indflydelse, Bertel Heurlin

Forbeholdets pris: EU's nye forsvarssamarbejde,

Christine Nissen og Jakob Dreyer

Danskerne og Rusland: Der plejer ikke at blive krig,

Michael Hesselholt Clemmesen

Sikkerhed i en digital tidsalder?, Niels Byrjalsen og Kristian Søby Kristensen

32

Migration som trussel mod sammenhængskraft, Frede Vestergaard

USA's udenrigspolitik under Trump - på afveje eller bare på Twitter?,

Annegrethe Rasmussen

\section{ARTIKELKONKURRENCE}

Danmarks udenrigs- og sikkerhedspolitiske strategi: Less is more, Jakob Dreyer 56

En højteknologisk sikkerhedspolitik, Mathias Terp Jensen

62

Er der et europæisk hukou-system i støbeskeen?, Birgitte Egeskov Jensen

\section{BAGGRUND}

Merkels sidste sejr, Lykke Friis

Zimbabwe 2.0, Peter Tygesen

Iran: Hverken brød eller frihed, Ali Alfoneh

\section{LITTERATUR}

Nedrustningsbegrebets lange vej gennem folkeretten, Henrik Døcker

Bognoter

\section{FORSIDEFOTO:}

Fra Frømandskorpsets 60-års jubilæum. 


\section{Fra redaktionen}

Forsvaret og Danmarks sikkerhed har i den senere tid været højt placeret på den politiske dagsorden. I juni 2017 præsenterede regeringen sin udenrigs- og sikkerhedspolitiske strategi 2017-2018 som opfølgning til Peter Taksøe-Jensens udredning om Danmarks udenrigs- og sikkerhedspolitik, og den 28. januar i år præsenteredes så det ny forsvarsforlig, der var indgået mellem regeringen og Dansk Folkeparti, Socialdemokratiet og Det Radikale Venstre, og som frem til 2023 skal styrke forsvaret.

Udenrigs vil gerne bidrage til debatten, og temaet for dette nummer er derfor de sikkerhedspolitiske udfordringer, som Danmark står overfor her i begyndelsen af det 21 . århundrede. Bertel Heurlin indleder med en analyse af, hvordan de tre former for verdensorden, den multipolære, den bipolære og den unipolære, har haft indflydelse på Danmark og Danmarks sikkerhed fra Anden Verdenskrig til i dag. Christine Nissen og Jakob Dreyer tager fat på det problem, at når EU i lyset af den ændrede sikkerhedspolitiske virkelighed lancerer en række ny forsvarspolitiske initiativer, så risikerer Danmark på grund af sit forsvarsforbehold at stå udenfor. Michael H. Clemmesen retter i sin artikel en skarp kritik af den ifølge forfatteren udbredte opfattelse, at et russisk angreb på de baltiske lande og eventuelt Bornholm er utænkeligt, og han påviser, hvor mange styrker det i virkeligheden ville kræve at forsvare den lange baltiske landgrænse. Niels Byrjalsen og Kristian Søby Kristensen diskuterer, om det er muligt for åbne samfund at skabe sikkerhed i en digital tidsalder. Cybertruslen er måske ikke den største trussel, men det er i høj grad et område, hvor man mangler svar. Frede Vestergaard beskæftiger sig med migration som en sikkerhedspolitisk trussel, fordi den på sigt kan true sammenhængskraften i vort samfund. Og endelig ser Annegrethe Rasmussen på den usikre faktor i det udenrigs- og sikkerhedspolitiske billede: USA's præsident Donald Trump.

Efter temaet bringer vi de tre vinderartikler fra Det Udenrigspolitiske Selskabs og Udenrigsministeriets artikelkonkurrence, der meget passende også handlede om sikkerhedspolitik.

I baggrundssektionen har Lykke Friis skrevet om Merkel og det tyske valg, Peter Tygesen om Zimbabwe 2.0 og Ali Alfoneh om de tilbagevendende politiske rystelser i Iran, og i litteratursektionen har Henrik Døcker anmeldt John Kierulfs bog om nedrustning $\mathrm{i}$ et folkeretligt perspektiv.

God læselyst! 


\section{Kluimme:}

\section{Rusland på afveje}

\section{Af Klaus Carsten Pedersen}

Sydossetiens væbnede styrker har længe været underlagt den russiske hær; men nu er det officielt. Dumaen i Moskva har ratificeret en aftale, der integrerer styrkerne i de russiske og underlægger dem russisk kommando. Det er også det mest praktiske, da den russiske hær står overalt i Sydossetien og er mange gange større end den sydossetiske.

Sydossetien er en af de to georgiske provinser, som Rusland 'befriede' i august 2008 i en krig, der varede fem dage. Krigen var fremprovokeret af Rusland, som havde forberedt sig længe og grundigt. Formålet var at stoppe Georgiens tilnærmelse til NATO, som Rusland har valg at definere som sin hovedmodstander.

Det er umuligt at sige, hvor mange mennesker der for tiden bor i Sydossetien. Georgierne er etnisk udrenset, og nogle osseter er fortrukket nordpå eller til slægtninge i Georgien. Man kan gætte på, at der bor 50.000-70.000, hvoraf op mod halvdelen er russiske soldater og administratorer med familier. Forbindelsen nordpå sker ad luftvejen eller den eneste landevej gennem Kaukasusbjergene.
Provinsen ligger midt i Georgien og er lidt større end Fyn. I nord grænser den til den russiske autonome republik Nordossetien, og i syd er den kun fă kilometer fra hovedvejen og jernbanen mellem Georgiens hovedstad Tblisi og havnebyerne Poti og Batumi ved Sortehavet. Dermed er Georgien ekstremt sårbart, for russerne kan fra deres baser i Sydossetien i en håndevending kappe Georgiens rygrad og i realiteten dele landet i to og lamme det.

Rusland anerkendte i 2008 regionen som selvstændig stat, men er helt åbenbart i færd med at annektere den. Processen er interessant og værd at studere, for den er med variationer gentaget på Krim og i det østlige Ukraine. Man uddeler russiske pas til dem, der måtte ønske det. Så lader man foretage nogle provokationer, fx beskydning af politistationer og landsbyer, og når reaktionen kommer, slår man til og kommer sine betrængte 'landsmænd' til hjælp imod 'overgrebene'. Der er selvfølgelig ikke tale om erobring - de såkaldte landsmænd vil før eller senere efter en folkeafstemning selv anmode om indlemmelse i Rusland.

Klaus Carsten Pedersen er cand.polit., han var Det Udenrigspolitiske Selskabs direktør 1987-2013. 
Der er ikke noget at sige til, at andre nabolande med russiske mindretalsbefolkninger er nervøse. Foruden Ukraine drejer det sig om Moldova, hvor den russiske hær har stået i Transnistrien i 27 år, Kasakhstan og Baltikum - især Estland, hvor befolkningen i nordøst er helt overvejende russisk. Balterne har dog NATO i ryggen. Det burde gøre dem lidt mindre nervøse, men os måske en anelse urolige.

Det er sørgeligt, at Rusland har udviklet et nul-sum-syn på sin omverden: hvad der er godt for naboerne, er skidt for Rusland og omvendt. Havde Rusland villet, kunne det have etableret gode venskabelige forhold til alle sine små nabolande. Men man vil have indflydelse og respekt og definerer desværre respekt på samme måde, som rockerbanderne gør det. Man vil hellere frygtes end elskes. Man kunne også have bevaret et godt forhold til NATO, alliancen mellem Ruslands vigtigste handelspartnere, dér hvor rige russere investerer deres penge, $\mathrm{k} \emptyset$ ber fast ejendom og sender deres unge på college. Men man har, helt banalt, brug for en ydre fjende for at legitimere sin interne magtudøvelse.

Det gør det lidt vanskeligt at håndtere russiske provokationer. Finder man sig i dem, fortsætter de, og det kommer til at ligne en russisk succes. Siger man fra, $\mathrm{fx}$ med sanktioner eller med en lidt skarpere forsvarsprofil, bekræfter man regimets påstand om, at NATO ikke vil Rusland det godt. Strategien må være at samarbejde med russerne, hvor det er fornuftigt og muligt, men samtidig holde ualmindelig godt øje med, hvad de foretager sig - især i vort nærområde - og kommunikere det klart og tydeligt verbalt og i handling, hvis vi føler anledning til uro.

Det nye forsvarsforlig ser ud til at forbedre mulighederne for begge dele. 


\section{Danmark:}

\section{Et land under indflydelse}

\section{Af Bertel Heurlin}

I 1965 udgav Per Hækkerup som udenrigsminister den første populære og autoriserede fremstilling af samtidens danske udenrigspolitik. Her fastslog han bl.a., at et lille land er fundamentalt anderledes stillet end en stormagt, at stormagterne og spillet mellem dem afgør først $\mathrm{og}$ fremmest verdensudviklingen, og at et lille lands udenrigspolitik derfor fortrinsvis består $i$ at tilpasse sig verdensudviklingen.

Per Hækkerups beskrivelse svarer helt til andre tidligere danske udenrigsministres opfattelse. Således fastslog Erik Scavenius i sin bagudskuende bog fra 1948 Forhandlingspolitikken under besoettelsen, at "Bestemmende for dansk udenrigspolitik må ... nødvendigvis til ethvert tidspunkt blive Danmarks stilling mellem stormagterne ..." Sådan har Danmark set sig selv lige siden det store tab i 1864. Danmark må tilpasse sig den gældende verdensorden, og det vil i realiteten sige den gældende orden, som den er udtrykt i relationerne mellem stormagterne.

Denne artikel tager udgangspunkt i disse betragtninger og den måde, de teoretisk er udformet i den forskningstilgang, som hviler på strukturel realisme. 'Neorealismen', som den også betegnes, er udformet af Kenneth Waltz. Der bruges en udvidelse af teorien til også at gælde unipolaritet, skabt af Birthe Hansen (Unipolarity and World Politics, Routledge 2011). Artiklen beskriver de tre former for verdensorden, den multipolære, den bipolære og den unipolære, som har ydet indflydelse på Danmark fra Anden Verdenskrig til i dag.

Dernæst redegøres der for de strategier, som Danmark har benyttet for at tilpasse sig de internationale vilkår, som de skiftende verdensordner stiller landet overfor. Strategierne tolkes i den strukturelle realismes teoretiske termer. Udgangspunktet er 'magtbalanceteorien', som hævder, at stater vil være tilbøjelige til at balancere den stærkeste magt. Det finder normalt ikke sted under unipolaritet, da kapabilitetsforskellene er så store, at der intet kan vindes. Her suppleres med begreberne 'flocking/freeriding. 'Flocking' betyder, at der på vitale sikkerhedspolitiske områder bakkes op omkring supermagten. 'Freeriding' relateres til strategier, der udnytter systemets stabilitet. 'Issue-balancing' er forsøg på balancering på meget specifikke områder. 'Management' er supermagtens udøvelse af magt i det internationale system.

Dernæst foretages en simpel analyse af

Bertel Heurlin er professor i europæisk sikkerhed og integration, Institut for Statskundskab, KU, Director, China Security Studies, Centre for Military Studies, UCPH, tidligere forskningschef for DUPI. 


\section{Danmarks sikkerhedspolitik under og efter den kolde krig}

DEN KOLDE KRIG

Placering og rolle:

Udsat frontliniestat

Småstat

Forbruger af sikkerhed

"Bad-boy" i NATO

Politik:

Frihjuls-politik

Tilpasning

Indenrigspolitik

Fodnoter

Dagsordener

Værdifastholdelse

Militæret afpolitiseret
EFTER DEN KOLDE KRIG

Placering og rolle:

Sikker centerstat

Stormagtsorienteret

Producent af sikkerhed

"Best-boy" i NATO

Politik:

"Hard-work" politik

Aktivisme

Internationalisme

Fodslag

Verdensorden

Værdifremme

Militarisering af udenrigspolitikken

Fra: Heurlin, Bertel: Krig og Fred i det 21. Århundrede. Samfundslitteratur, København, 2009

Danmarks kapabiliteter i perioden, og endelig følger en undersøgelse af truslerne mod Danmarks vitale nationale mål.

\section{Indflydelse, kapabiliteter, verdensorden}

Kort og godt: Danmark er et land under indflydelse. Det er alle småstaters vilkår. Indflydelsen kommer udefra og mere præcist fra den gældende verdensorden. Danmark indgår i denne verdensorden i kraft af sine kapabiliteter. Verdensordenen kan forstås på mange måder. Her ses den som et udtryk for magtfordelingen og er magtudøvelsens anker. Den forklarer varierende politiske udfald. Verdensordenen fungerer som en konstant, som ikke udskiftes tit og ofte.

Ikke desto mindre kommer denne artikel til at beskæftige sig med ikke mindre end tre former for verdensorden: en mulitipolær, en bipolær og en unipolær. Verdensordenen er udskiftelig. Det er Danmark ikke. Men landet er markant forandret i løbet af de snart 75 år, der er gået siden Anden Ver- denskrig ophørte og førte til en kold krig. Den kolde krigs afslutning afslørede en ny verdensorden. Den blev båret af en omfattende optimisme og drivkraft. Den så ud til at fjerne muligheden for verdenskrige, kolde som varme.

Multipolor verdensorden: De to verdenskrige fandt sted under en multipolær verdensorden. Virkningerne var katastrofale. Tabene og ødelæggelserne uhørte. Multipolaritet er baseret på tre til syv stormagter, som balancerer hinanden ved at indgå i skiftende alliancer. Resultatet er generel ustabilitet.

Bipoloer verdensorden: Men knap var Anden Verdenskrig afsluttet før alvorlige konflikter brød ud. I 1946 holdt Churchill sin berømte tale om, at "der fra nord til syd var sænket et jerntæppe gennem Europa." Var der en ny verdensorden på vej?

Den ny verdensorden kom snigende. Det var de to sejrherrer i Anden Verdenskrig, som nu havde erhvervet samlede ka- 


\section{Verdensordenen er udskiftelig. Det er Danmark ikke. Men landet er markant forandret i løbet af de snart 75 år, der er gået siden Anden Verdenskrig ophørte og førte til en kold krig.}

pabiliteter, som måtte kvalificerede dem som de to eneste stormagter i verden. Det var oplagt, at de fik betegnelsen supermagter. Men allerede mindre end 45 år senere opstod atter en ny verdensorden. Et helt unikt syn i verdenshistorien. Den nye verden startede i september 1989 og var fuldt udfoldet i 1991. I denne korte tid udfoldedes den mest spektakulære og bemærkelsesværdige politiske proces i verdenshistorien: Afslutningen af den kolde krig.

Unipolor verdensorden: Den kolde krig foregik på alle de måder, krige normalt blev udkæmpet på. Undtaget var konkret udveksling af ødelæggelseskraft, brug af fysisk militær vold og blodsudgydelse. Men det gjaldt kun på de områder, som de to supermagter havde valgt som deres basale interessesfærer. Øst-vest-krigen kunne kaldes en virtuel krig. Dér, hvor interessesfærerene ikke var fastlagt, var der imidlertid frit slag for stedfortræderkrige. Den kolde krig lå tungt og truende over verden. Som om den aldrig skulle høre op. Men pludselig var det hele ovre.

Det unikke var, at verden oplevede, at to supermagter blev til en. Endnu mere unikt var det, at processen var baseret på en fredelig og frivillig kapitulation. Sovjetunionens imperium blev opløst. Først trak USSR sig tilbage fra sine globale positioner, Afghanistan og Vietnam, dernæst fra Østeuropa for til slut at opløse sig selv. Uden blodsudgydelse. Tilbage stod USA som enesupermagten.

Dermed var det system skabt, som definerer verdensordenen i dag. Det er det system, Danmark er under indflydelse af $\mathrm{i}$ dag.

\section{Danske strategier}

Hvordan forholder Danmark sig til disse verdensordensskift, fulde af muligheder og farer?

Danmark vælger ikke overraskende tre forskellige former for tilpasningsstrategier. Småstater som Danmark må tilpasse sig. Inden for alle tre verdensordenstyper vil småstater være meget sårbare for udslettelse, selv om dødsraten for stater ikke er markant. Men småstater er ganske udsatte - mindst under unipolaritet, mest under multipolaritet. I midten ligger bipolariteten, hvor risikoen for 'finlandisering' er større end risikoen for udslettelse. Det gælder også Danmark. Danmark var i næsten konstant eksistenskrise frem til 1945. Under øst-vest-konflikten var faren for et sovjetisk angreb i den grad til stede. Det kunne betyde en total fysisk udslettelse af nationen gennem et kernevåbenangreb.

Unipolariteten giver den største sikkerhed for at undgå udslettelse medmindre man får den amerikanske mærkat at være en 'rogue' stat, en slyngelstat. Der er ingen tvivl om, at 1989 for Danmark var et historisk skifte. Aldrig tidligere i nyere tids historie har dansk eksistens været sikrere. Det er et bemærkelsesværdigt skifte, når der blot ses årtier tilbage.

Men hvilke strategier har Danmark benyttet for ikke alene at sikre sin eksistens, men også at bevare sine overordnede mål i relation til det internationale system, til den gældende verdensorden?

\section{Strategier under multipolaritet}

Hvis vi ser på perioden fra skæbneåret 1864 til 1945, altså under den hersken- 
de multipolaritet, har Danmarks strategi været at ligge så tæt som muligt i forhold til stormagten Tyskland. Tyskland skulle være overbevist om, at Danmark aldrig ville indgå i en alliance rettet mod Tyskland. Dansk sikkerhed skulle opretholdes ved en 'flocking'-politik i forhold til Tyskland. At balancere Tyskland var ikke muligt. Forsigtige forsøg afslørede denne kendsgerning. Der var kun en realistisk option. På det diplomatiske plan var der spæde forsøg på 'freeriding' ved at spille neutralitetskortet.

\section{Lmåstater som Danmark må tilpasse sig. Inden for alle tre verdensordenstyper vil småstater være meget sårbare for udslettelse, selv om dødsraten for stater ikke er markant.}

Mineudlægningen i 1914, som var et tysk krav, demonstrerede vanskelighederne. 'Freeriding' blev også forsøgt efter det tyske nederlag i Første Verdenskrig ved at satse på Folkeforbundet, men uden nogen gennemslagskraft på længere sigt. Ikke-angrebspagten fra 1939 efterfulgt af besættelsen markerede den mest fundamentale 'flocking. Der var desperate forsøg på 'freeriding' ved at hævde 'besættelsesneutralitet'. Det, der kom Danmark til hjælp, var den efterhånden magtfulde anti-tyske alliance.

Som Tysklands totale nederlag blev mere og mere synligt, blev det ved tidernes gunst og ved effektivt diplomati muligt for Danmark at skifte side og derefter at flokkes omkring de globale sejrherrer med fastholdelse af et gran af den overordnede neutralitetspolitik. Da bipolariteten i slutningen af 1940'erne var fuldt erkendt, var det forbi med 'freeriding' i form af neutralitetsstrategi.

\section{Strategier under bipolaritet}

Den bipolære verdensorden vendte op og ned på Danmarks position. Verden blev delt i to globale systemer styret af hver sin magt, som kapabilitetsmæssigt skilte sig ud fra de øvrige stater. Det var supermagterne USA og USSR. De ikke alene konkurrerede, men bekæmpede hinanden. Det skete med alle midler, militære, økonomiske og politiske.

Hvordan stillede Danmark sig under disse nye vilkår? Hvordan skulle man tilpasse sig denne nye indflydelse? Som nævnt flokkedes Danmark i første omgang omkring de allierede sejrende magter, men da verden blev polariseret, måtte der vælges side. Europa blev delt i to, og da Danmark lå så tæt ved skillelinjen, som det overhovedet var muligt, blev valget både let og svært. Let fordi landet lå i den amerikanske indflydelsessfære. USA og Sovjetunionen havde delt Europa mellem sig. Europa oplevede sin 'Stunde Null'.

USA kunne sikre Danmark mod en tjekkoslovakisering, mod at blive en sovjetisk vasalstat og mod en mulig sovjetisk militær aggression. Så en snæver og tæt 'flocking' omkring USA var et indlysende valg. Alligevel var det svært, fordi Danmark ikke var interesseret $i$ at se sig selv - eller blive set - som en amerikansk vasalstat, fordi landet havde en interesse $i$ at undgå en tilspidsning af øst-vest-konflikten. Dertil kom en interesse i ikke at blive opfattet som en frontlinjestat, hvorfra et vestligt angreb på USSR kunne finde sted.

Her var et klart dilemma, som mere eller mindre konsekvent søgtes løst ved forskellige former for 'freeriding' i forhold til den vestlige blok. Denne 'freeriding' var gældende i forskellige europæiske lande, som tilhørte NATO-alliancen. Yderst stod Frankrig, som under størstedelen af den 
kolde krig stod uden for NATOs alliancestruktur. Danmark lå i midten, med forbehold over for stationering af fremmede tropper, forbehold over for kernevåbenstationering og -strategi og særlige forbehold i forbindelse med Bornholm. Tættest på USA lå Vesttyskland, som repræsenterede den centrale militære øst-vest-frontlinje med over to millioner fremmede tropper fast stationeret og med en massiv tilstedeværelse af militært materiel.

Danmarks medlemskab af NATO var således klart et medlemsskab med betydelige forbehold. På et tidspunkt under den kolde krig fik dette forbeholdssystem endog en særlig betegnelse.'Danmarkisering' blev et udtryk for et land, som primært var forbruger af sikkerhed i alliancen. Produktion af sikkerhed var begrænset. Man kørte på frihjul. Der var en betydelig grad af 'freeriding' i den danske politik under den kolde krig, som ikke mindst blev markeret i den lange fodnoteperiode i 1980 'erne. Danmarks valg under den kolde krig var således en klar 'flocking' omkring supermagten USA suppleret med en betydelig 'freeriding' i den øst-vestlige konflikt.

\section{Strategier under unipolaritet}

Efter den kolde krigs afvikling ved Sovjetunionens kapitulation stod Danmark under indflydelse af et 'single super power system, teoretisk betegnet som unipolaritet. Hvilke ændringer betød det i Danmarks overordnede sikkerhedspolitiske strategi? Danmark var et af de lande, som først forstod rækkevidden og konsekvenserne af den nye verdensorden.

Hvor den overordnede sikkerhed under den kolde krig havde været udelelig, forstået som det forhold, at global sikkerhed primært måtte ses i et øst-vestligt, bipolært perspektiv, var sikkerheden nu de- lelig. Sikkerhedsproblemerne spredtes til at være individuel, 'human security', social sikkerhed, snæver national, etnisk betonet sikkerhed, global sikkerhed som miljø, klima, pandemier, terrorisme. Det er i virkeligheden et udtryk for, at den enkelte stat selv i højere grad end under den kolde krig må tage ansvar for at placere sig selv i den nye sikkerhedspolitiske sammenhæng. Hvor der for staterne under bipolariteten i princippet var en mulighed for at vælge mellem den ene eller den anden supermagt, som dermed gav en vis forhandlingsmagt, eksisterer denne mulighed ikke under unipolariteten. Teorien siger, at unipolariteten dermed lægger op til 'hårdt arbejde' for den enkelte stat.

For Danmark blev situationen den, at der blev satset på en meget klar 'flocking'-strategi, som indebar, at man på alle væsentlige sikkerhedspolitiske parametre skulle følge USA. Det betød, at enhver 'freeriding' blev undgået og at en 'hårdt arbejde'-strategi blev søgt gennemført for gennem USA at styrke Danmarks generelle internationale position.

Den markante 'flocking'-strategi har været gældende med uforandret kraft siden unipolaritetens første tid til i dag. Den har ikke mindst betydet, at Danmarks universalistiske politik med en kraftige satsning på FN er blevet svækket, ikke mindst i relation til den meget omfattende danske deltagelse i militære interventioner udført af det internationale samfund gennem ad hoc-koalitioner primært ledet af USA.

Det centrale skel er 1999, hvor Danmark går i krig uden et klart mandat fra FN’s sikkerhedsråd. Denne politik fortsætter uanset regeringssammensætning. Således bliver det i 2011 og 2013 klart tilkendegivet af statsminister Helle Thorning Schmidt, at Danmark 'ved 


\section{I Taksøe-redegørelsen fra 2016 om dansk udenrigspolitik kunne det konstateres, at Kongeriget Danmark i 'arktisk henseende er en stormagt'. Men samtidig må det understreges, at dansk territorium igen kan skifte, i tilfælde af at Grønland erklærer sig som en uafhængig stat, hvorefter Danmark vil blive reduceret til en post-arktisk stat.}

et entydigt og akut behov for humanitært begrundet international intervention' kan handle uden accept fra sikkerhedsrådet.

Spørgsmålet om, hvorvidt ændringerne i de internationale forhold forårsaget af ikke mindst en ny amerikansk regering under Trump, som fremtræder protektionistisk, isolationistisk og uden ønske om verdenslederskab, samt dybe problemer for europæisk integration i form af renationaliseringstendenser vil betyde ændringer i den danske markante 'flocking'-strategi, er påtrængende.

Ser vi på situationen, er der imidlertid ikke nogen tegn på, at USA er ved at abdicere som supermagt. Tværtimod er vurderingen generelt den, at ændringerne i kapabiliteterne i international sammenhæng ikke på nogen måde kan pege på fremkomsten af endnu en bipolær eller en multipolær verdensorden. Der er ingen tegn på fremkomsten af en koalition af magter, som står sammen om at balancere USA. Uanset politisk adfærd eller forskellige bemærkelsesværdige udsagn fra Trumps side må unipolariteten ses som robust. Det er i sidste instans kapabiliteterne, der tæller.

\section{Tre verdensordners indflydelse}

Verdensordenerne har ændret sig grundlæggende og med små intervaller i de seneste små 75 år. Men hvad med Danmark? Har Danmark grundlæggende været konstant - og hvis ikke, hvordan har relationerne været mellem ændringerne i verdensordenen og ændringerne i Danmark? Hvordan ser det ud med
Danmarks kapabiliteter? Her vil Kenneth Waltz' simple kapabilitetsmodel være udgangspunktet.

'Territoriet' har vel næppe ændret sig. Og dog. I realiteten har der været grundlæggende ændringer. Det danske landkort ændrede sig alene i 1960'erne fundamentalt. Motorveje og broer overalt. Alle byer fik parcelhuskvarterer, industrikvarterer og omkørselsveje. Landbrugsarealer blev sammenlagt og intensiveret. Vigtigt er udvidelsen af territoriet. I $1953 \mathrm{blev}$ kolonien Grønland en del af Danmark. I 1979 fik Grønland hjemmestyre og i 2009 selvstyre, som betød, at kun forsvars- og udenrigspolitik skulle varetages af danske institutioner. I Taksøe-redegørelsen fra 2016 om dansk udenrigspolitik kunne det konstateres, at Kongeriget Danmark i 'arktisk henseende er en stormagt'. Men samtidig må det understreges, at dansk territorium igen kan skifte, i tilfælde af at Grønland erklærer sig som en uafhængig stat, hvorefter Danmark vil blive reduceret til en post-arktisk stat.

'Befolkningen' har ændret sig. Der er kommet flere indbyggere. Danmark er nu gennemurbaniseret. Uddannelsesmæssigt er det mest markante, at andelen af borgere med højere uddannelse er steget markant. Indvandringen til Danmark, der startede i 1960'erne, og som er kulmineret i de seneste år med omfattende flygtningestrømme, har betydet, at andelen af nydanskere er steget voldsomt. Sociologisk set er befolkningen generelt blevet mere enkeltindividorienteret med styrkelse af konkurrenceorientering frem for familietilknytningen. 
'Økonomien' har oplevet revolutionslignende ændringer. Danmarks erhvervsmæssige og økonomiske forhold demonstreres bedst ved se på udviklingen fra et markant landbrugsland til et højt industrialiseret land, som for øjeblikket udvikles til et videnssamfund og til et samfund baseret på højteknologi og IT-udvikling. Hertil kommer ikke mindst fra de sene 1950'ere udviklingen af et velunderbygget og systematisk velfærdssamfund. I nullerne ses en udvikling fra velfærdssamfund til konkurrencesamfund, ganske vist med indbyggede velfærdsgoder.

Taler vi om 'ressourcer', er der sket en udvikling fra landbrugsjord som den væsentlige ressource til Danmark som energiproducerende land med selvforsyning via gas og olieforekomster og nu med vægt på alternative energiformer. Grundlæggende satses der på de ressourcer, som udvikles via et udbygget videnssamfund.

\section{Militære kapabiliteter}

De danske militære kapabiliteter har tilsvarende ændret sig. I 1945 var det danske militær ikke-eksisterende. Tyskerne havde i 1943 fjernet de sidste dele af det danske forsvar. Fra 1944 blev der opbygget en dansk brigade i Sverige, som kom til Danmark efter krigsafslutningen. Herfra skulle et nyt militær opbygges, delvist baseret på modstandsbevægelsen. I princippet blev der søgt købt militært materiel både fra øst og vest. Neutraliteten fungerede fortsat.

Med Danmarks indtræden i NATO fik Danmark en militær styrke, som var på højde med tilsvarende lande. Danske styrker deltog også i besættelsen af Tyskland, som svarede til, at det var et dansk mål frem til begyndelsen af 1950'erne, at Tyskland skulle afmilitariseres.
Det blev dog hurtigt ændret i forbindelse med skærpelsen af den kolde krig. På den længere bane blev der etableret et tæt militært samarbejde med det nye tyske militær som en naturlig del af NATOs militære integration. Netop den militære integration var afgørende: Det danske militær gav primært kun mening ved at indgå i alliancen. Det var helt nyt for Danmark. Danmark blev forberedt på at modtage forstærkninger, og danske styrker indgik også i forsvaret af Tyskland. Men der var generelt i NATO ikke den største respekt for den danske indsats målt i kroner og ører. Afgørende var imidlertid, at for første gang siden 1864 kunne Danmark forsvares.

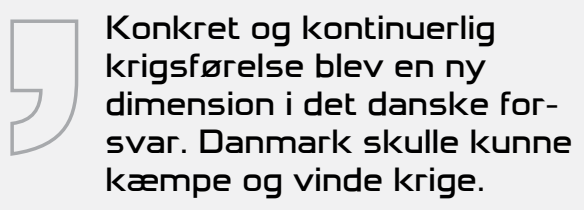

Forholdet til alliancen ændredes markant efter den kolde krig. Danmark indledte en ny strategi, som betød en militarisering af udenrigspolitikken i den forstand, at militæret blev anvendt som et udenrigspolitisk middel på linje med ulandshjælp og generelt diplomati.

Det danske militær ændredes fundamentalt. Først og fremmest har man søgt at tilpasse sig den generelle udvikling inspireret af RMA (Revolution in Military Affairs), som indledes i USA i 1980'eren og fik sit store gennembrud efter den kolde krig. Afgørende var ændringen fra primært at være et territorialt forsvar inden for NATO-integrationens rammer til at være organiseret som deployerbare styrker med det formål at kunne indsættes også som kamptropper over alt i verden, hvis det internationale samfund 
besluttede det. Konkret og kontinuerlig krigsførelse blev en ny dimension i det danske forsvar. Danmark skulle kunne kæmpe og vinde krige. Sådan havde det ikke været set siden 1864 .

\section{Stabilitet og kompetence}

Tilbage står kapabiliteterne stabilitet og kompetence. Det er meget generelle og mindre eksakte kategorier, som også er vanskelige at sammenligne. De skal selvsagt ses i relation til den samlede vurdering af landets kapabiliteter. Grundlæggende må Danmark betragtes som en stabil og kompetent enhed i international politik.

Der er basalt en politisk konsensus om de udenrigspolitiske linjer, og Danmark vurderes som et land med minimal korruption, med et kompetent embedsapparat og en robust økonomisk-politisk styring. Der er udsving i retning af at balancere på den 'økonomiske afgrunds rand' og balancere i relation til en for de internationale omgivelser uforståelig fodnotepolitik under den kolde krig. Men det rokker ikke ved det store billede.

Danmarks samlede kapabiliteter viser en småstat, som har formået at overleve og som generelt har en solid international standing. Men hvordan har de tre verdensordener influeret på kapabiliteterne? Har Danmark formået at opbygge og styrke kapabiliteterne som en del af magtbalancen?

Overordnet må det konstateres, at det er lykkedes Danmark i perioden fra overgangen fra multipolaritet til bipolaritet til situationen i dag i relation til andre småstater at forbedre egne kapabiliteter. Danmark rangerer høj på en række centrale samfundsmæssige dimensioner, og Danmark har også på det globale sikkerhedsmæssige område ydet en indsats som værdsættes i den unipolære verdensorden. Der er vurderinger, som hævder, at Danmark har hævet sig over det generelle småstatsniveau.

\section{Danmarks udenrigspolitiske mål}

Men hvordan har de skiftende verdensordener ydet indflydelse på Danmarks kapacitetssituation i forhold til de sikkerhedspolitiske trusler i overordnet sammenhæng? Hvordan er det gået med at opretholde Danmarks mål som enhed i det internationale system?

Teoretisk set vil en stat som afgørende mål have eksistensen, dvs. at være en defineret og anerkendt enhed i systemet. Dernæst kommer to former for suverænitet: At kunne føre en selvstændig udenrigspolitik og at have fuld autonomi på det indenrigspolitiske område. Endvidere at have sikret integritet på to områder, geografisk og befolkningsmæssigt. De to sidste mål handler om økonomisk fremgang og at etablere fredelige omgivelser, dvs. sørge for at omgivelserne ikke er i modsætning til ens eget samfundssystem. Fx har Danmark udenrigspolitisk satset på at fremme fred, udvikling og demokrati.

Eksistens er det fundamentale mål. For Danmarks vedkommende var eksistensen på spil under multipolariteten, mest markant under besættelsestiden. Men truslen fortsatte efter krigsafslutningen. Påskekrisen i 1948 demonstrerede, at der kunne være en eksistenstrussel, som ville kunne udvikles til et resultat, hvor Danmark endte som sovjetisk lydstat. Det gav ekstra vægt i overvejelserne om tilslutning til NATO.

Den følgende markante eksistenstrussel lå latent i den bipolare verdensorden: Truslen om kernevåbenkrig. Det kom i Dannmark til at spille en central rol- 
le. Koldkrigsperioden svingede mellem spænding og afspænding. Danmark arbejdede bevidst mod afspænding og ydede for eksempel en kraftig støtte til NATOs Harmel-rapport, som fremhævede, at afskrækkelsesstrategier var centrale, men hånden skulle rækkes frem til forhandlinger om afspænding og våbenkontrol.

Generelt var Danmark under øst-vest-konflikten mere bekymret for 'entrapment' i alliancen, og i yderste konsekvens at blive inddraget i noget, som kunne minde om en sejrsstrategi eller en befrielsesstrategi mod USSR, end 'abandonment', dvs. at blive efterladt af alliancen. En vigtig faktor her var Danmarks strategiske placering i forhold til Warszawa-pagten, som udelukkede, at NATO ikke ville forsvare Danmark.

Atomspørgsmålet var som nævnt centralt under hele den kolde krig. Det blev et eksistensproblem af to grunde. Dels var det almindelig kendt, at Danmark, hvis en øst-vest-krig brød ud, ville blive et af de første mål. Danmark ville blive plastret til med sovjetiske atom- og brintvåben. Selvom socialdemokratiske regeringer i den kolde krigs første perioder ikke var afvisende over for dansk inddragelse af NATOs atomstrategier, var Anker Jørgensens regeringer i stigende grad blevet skeptiske og negative over for vestlige kernevåbenstrategier. Ikonisk blev Anker Jørgensens udsagn: 'Atomvåben er noget skidt'.

Atomvåbnene blev et eksistensproblem: Danmark ville fysisk forsvinde, hvis krigen kom. Statsministeriet hus- standsomdelte i januar 1962 en 32-siders detaljeret pjece, Hvis krigen kommer. Den fortalte indgående om, hvordan man skulle overleve. Det kunne være at lægge et lag jord på stuegulvet og selv gå i kælderen. Men meget få forestillede sig overlevelse, hvis atomragnarokket gik i gang. Der var en overvældende tilslutning til forestillingen om, at det måtte aldrig ske. Damarks fysiske overlevelse var på spil!

Under den unipolære verdensorden var alt ændret: Den globale konflikt var væk. Der var ingen eksistenstrussel. Danmark var sikrere end nogensinde. Som det blev udtrykt i flere officielle publikationer, 'Der vil i overskuelig fremtid ikke være nogen konventionel trussel mod Danmark. Det var rene ord for pengene. Det er et udsagn, som - uanset russiske trusler - fortsat er gældende i 2018.

\section{Suverænitet og integritet}

Ser vi på suveræniteten - både udenrigspolitisk og indenrigspolitisk - var den alvorligt truet under multipolariteten. Under besættelsen var målet blot at have et minimum af suverænitet. Under bipolariteten blev det mål opfyldt. USSR forsøgte uden nævneværdig succes at påvirke Danmarks suverænitet. Det var klart lettere for USA at påvirke den, men det skete kun i begrænset omfang ( $\mathrm{fx}$ spørgsmålet om baser i Grønland).

Tilslutningen til EF fra 1973 blev af enkelte opfattet som nedlæggelse af Danmark. EF og senere EU kom forståelig nok til at spille en central rolle i dansk økonomisk politik, men kun i behersket grad i udenrigs- og sikkerhedspolitikken, og slet

\section{Som det blev udtrykt i flere officielle publikationer, 'Der vil i overskue- lig fremtid ikke være nogen konventionel trussel mod Danmark'. Det var rene ord for pengene. Det er et udsagn, som - uanset russiske trusler - fortsat er gældende i 2018.}


ikke i forsvarspolitikken. Det afgørende var, at den generelle danske politik betragtede visionen om 'an ever closer union' med skepsis og understøttede forestillingen om, at nok kunne medlemsstaterne 'poole' suverænitet på centrale økonomiske områder, men på andre områder skulle EU være en forening af suveræne stater.

Denne opfattelse var også gældende under verdensordenen efter 1989. Her blev problemet om den meget tæette 'flocking' omkring USA centralt. Men skiftende regeringer og officielle hvidbøger var ikke i tvivl. Det var i dansk interesse og medførte store politiske fordele at lægge sig tæt op ad USA.

Selv om USA i politiske debatter var genstand for omfattende kritik, ikke mindst i forbindelse med dansk krigsdeltagelse, fortsatte en politik, som en tidligere amerikanske ambassadør i Danmark beskrev som, at hvis USA havde ønsker om dansk deltagelse i militære interventioner, kunne man være sikker på, at det danske forsvarsministerium, når henvendelsen kom, allerede havde forberedt den aktive deltagelse.

I spørgsmålet om geografisk og befolkningsmæssig integritet er det vanskeligt at påpege de store forskelle mellem de forskellige verdensordner, når der lige ses bort fra Grønland og Arktisproblematikken, som allerede er omtalt. Befolkningsmæssigt er det imidlertid centralt at påpege, at da den unipolære verdensorden blev en realitet, åbnedes der op for politisering og såkaldt sikkerhedsliggørelse af alle hånde sikkerhedsorienterede fænomener heriblandt indvandring og flygtningestrømme.

Her blev problematikken fra den europæiske integration gentaget. Kan Danmark økonomisk, politisk og kulturelt rumme det indre markeds åbne grænser for arbejdskraft for slet ikke at tale om masseindvandring af antisekulære tredieverdenspersoner med kulturer fjernt fra den danske?

Det er et problem, som Danmark på ingen måde står alene med, men som fylder stadigt mere i dansk sikkerhedspolitik $\mathrm{i}$ bred forstand.

\section{Velstand, vækst og fredelige omgivelser}

Det fører videre til velstands- og vækstmålsætningen. Her er der næppe nogen tvivl om, at bipolariteten satte grænser for udvidelsen af Danmarks muligheder i konkurrencen om internationale markeder.

Med den unipolære verdensorden var der kun et og ikke to verdensmarkeder, selv om det socialistiske verdensmarked aldrig satte sig igennem. Den unipolære verdensorden har med sit liberale, verdensomspændende handels- og produktionsregime givet Danmark muligheder for at gennemføre en økonomisk globaliseringsstrategi, som på trods af den stigende konkurrence har givet Danmark komparative fordele.

Den sidste målsætning - sikring af fredelig omgivelser - forsøgte Danmark efter bedste evne under vanskelige sikkerhedspolitiske vilkår at leve op til under bipolariteten.

Unipolariteten gav hidtil uanede muligheder. I en unipolar situation vil enesupermagten have relativt frit spil til at præge det internationale system med sit eget globale og internationale projekt. USA har klart propageret for, på hvilket grundlag man vil sørge for at gennemføre en verdensorden. Det amerikanske internationale management er baseret på en verden som fremmer demokrati, markedsøkonomi, individuel frihed, menne- 


\section{Præsidenter kommer og går. USA består. Det er primært kapabilite- terne, der tæller, når Danmarks overordnede verdensordenstrategi skal videreføres.}

skerettigheder og international lov og orden. For Danmark er en amerikansk ledet unipolaritet den bedste af alle verdener. Den svarer i område på område helt til de udenrigspolitiske mål, som efterstræbes af Danmark.

Generelt kan det konstateres, at det er lykkedes Danmark at sikre Danmarks udenrigspolitiske mål. Mindst under multipolariteten, mere under bipolariteten og mest under unipolariteten.

\section{Konklusion}

At karakterisere næsten 75 års dansk sikkerhedspolitik er ikke nogen let opgave. Resultatet kan ikke undgå at blive skitseagtigt. En systemisk realismeteoretisk tilgang viser imidlertid, at det er muligt at kunne udpege væsentlige træk og centrale politiske udfald.

Undersøgelsen er tredelt.

For det første kan det med en simpel polaritetsmodel, hvor stormagtsrelationerne har en fundamental forklaringskraft, påvises, at Danmark har ført vidt forskellige overordnede strategier for at sikre landets overlevelse og trivsel under en multipolær, en bipolær og en unipolær verdensorden.

For det andet kan det ved gennemgangen af ændringerne i Danmarks kapabiliteter påvises, at kapabiliterne er svækket under multipolariteten, styrket under bipolariteten og markant styrket under unipolariteten - ikke mindst via Danmarks verdensordensstrategi, som er blevet karakteriseret som aktivisme eller endog pro-aktivisme.

For det tredje at det med gensyn til at opfylde og sikre danske udenrigs- og sikkerhedspolitiske mål er lykkedes mindst under multipolariteten, bedre under bipolariteten og bedst under unipolariteten.

Udgangspunktet for analysen var, at verdensordenen har en helt afgørende indflydelse på ikke mindst småstater. Men den har også vist, at verdensordenen skifter. I den periode, som er behandlet, optræder ikke mindre end tre typer verdensordener. Det vil sige, at der kan ske hurtige skift. Skiftene, som her behandles, er sket efter afslutningen af to verdensomspændende krige, Anden Verdenskrig og den kolde krig.

Forudsætter verdensordenskift afslutning på globale krige? En ting kan fastslås: Krige er en afgørende test af kapabilitetsrelationerne mellem stormagter. Hvad så med situationen i dag? Er vi ikke midt i et nyt verdensordenskift? Neorealismens fader, Kenneth Waltz udtrykte det meget kategorisk i 2000: "Man skal være meget nærsynet for ikke at se multipolariteten komme". Og overalt tales der om den begyndende multipolaritet.

I denne sammenhæng er det vigtigt at påpege, at unipolariteten snart har varet $\mathrm{i}$ 30 år. Den er robust. Stort set alle stater i verden opererer med det udgangspunkt, at der for tiden kun er en supermagt. Her bruges begrebet unipolaritet ikke. Begrebet anses for at signalisere magtbrynde og hegemoni.

Men vil Trump gå ind i rollen som verdens leder? Rolle- og socialiseringsteorier vil anse det for sandsynligt. Men det afgørende her er kapabiliteterne. Trump 
vil gøre USA stærkt igen, altså styrke kapabiliteterne. Så muligheden for en robust unipolaritet er klart til stede.

For Danmark er problemet, om man skal flokkes om Trump-regeringen. Her må svaret være: Præsidenter kommer og går. USA består. Det er primært kapabiliteterne, der tæller, når Danmarks overordnede verdensordenstrategi skal videreføres. 


\section{Forbeholdets pris: EUs nye forsvarssamarbejde}

Af Christine Nissen og Jakob Dreyer

Migrantstrømme, konflikter med Rusland, terrorangreb, Brexit og præsident Donald Trump har på kort tid forandret Europas sikkerhedspolitiske virkelighed. I lyset af forandringerne har EU i 2017 lanceret en række forsvarspolitiske initiativer, som kun få troede mulige for blot få år siden, herunder etableringen af et 'permanent, struktureret forsvarssamarbejde' og en forsvarsfond. Danmark står grundet sit forsvarsforbehold uden for denne udvikling og risikerer derfor at stå isoleret i en usikker tid.

Ideen om at tilføje en forsvarspolitisk dimension til EU-samarbejdet er ikke ny. Den har eksisteret siden tiden efter Anden Verdenskrig, hvor Frankrig, Italien, Vesttyskland og Benelux-landene tog initiativ til et fælleseuropæisk forsvarsforbund. Et forbund, der skulle skabe en overstatslig europæisk hær med fælles forsvarsbudget og kapabiliteter for de deltagende lande. Drømmen brast dog allerede i 1954, da det franske parlament nedstemte forslaget.

Efter mange års dvale og flere forfejlede forsøg, etablerede og operationaliserede EU i 2003 endelig sin egen sikkerhedsog forsvarspolitik, efter Balkan-krigene havde udstillet behovet for, at Europa blev i stand til at tage mere ansvar på den internationale scene.

EU's nye sikkerheds- og forsvarspolitik var dog ikke styret af traditionel sikkerhedstænkning om beskyttelse af det europæiske territorium og dets borgere, men i stedet af visionen om at skabe en mere fredelig verden gennem langsigtede missioner, der var fokuseret på at fremme europæiske værdier og typisk foregik i lande langt væk fra Europas geografiske kerne.

EU's nye rolle på den globale scene var således primært civil og humanitær, hvilket ikke mindst blev muliggjort af NATO og USA's sikkerhedsgaranti til de europæiske lande.

\section{Eksterne trusler og interne}

I dag gennemlever Europa en hurtigt skiftende sikkerhedspolitisk virkelighed. Rusland truer den europæiske sikkerhedsorden, krige i Mellemøsten og Afrika har ført store migrationsstrømme til

Christine Nissen er forsker ved DIIS, hendes primære forskningsområde er EU's udenrigs- og sikkerhedspolitik, herunder Den Europæiske Udenrigstjenestes virksomhed.

Jakob Dreyer er stud.scient.pol. og sprogofficer. Han er vinder af dette års artikelkonkurrence, og hans bidrag bringes på side 56 i dette nr. af Udenrigs. 


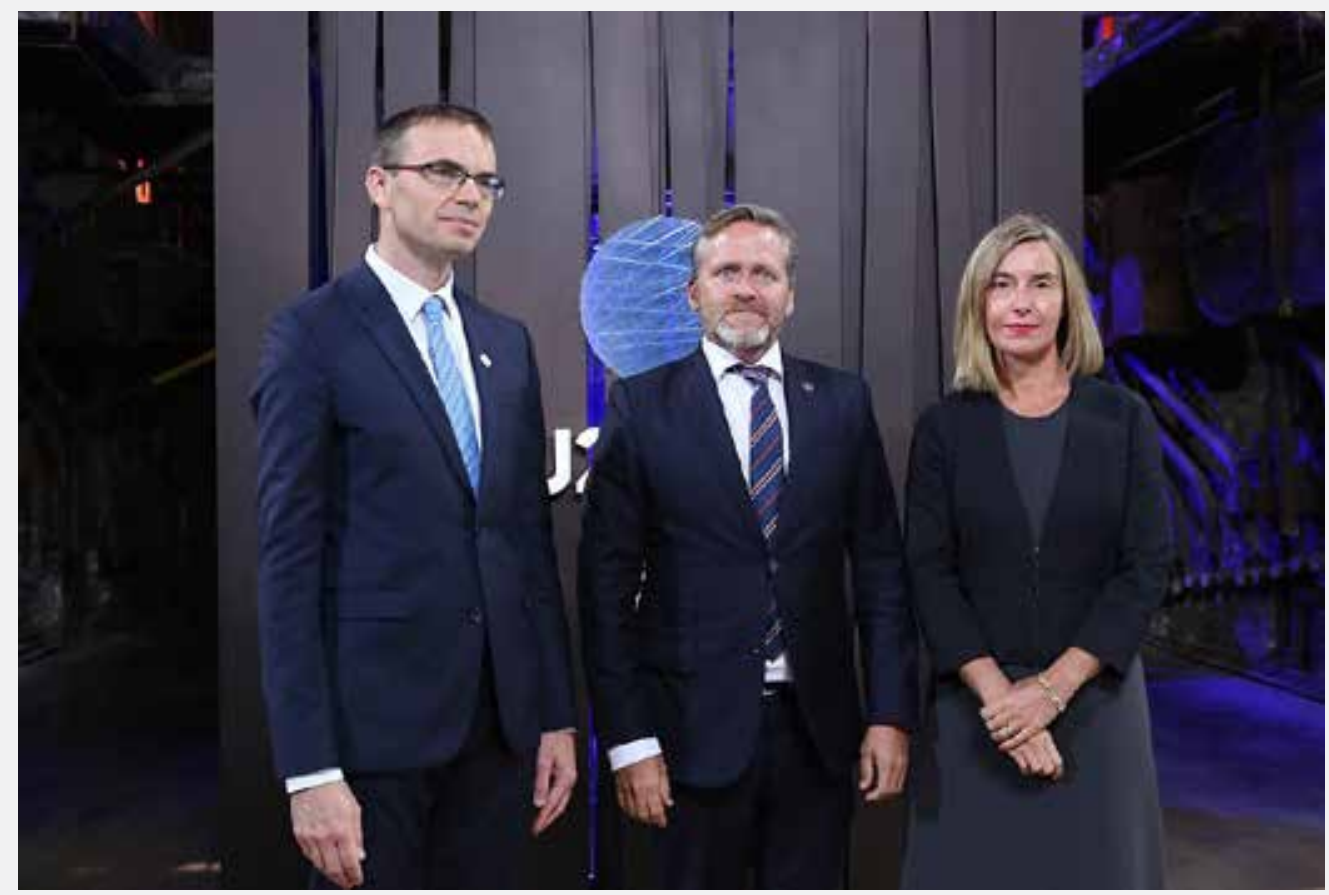

FOTO: EU2017EE Estonian Presidency via wikimedia commons

Udenrigsminister Anders Samuelsen sammen med EU's udenrigschef Federica Mogherini og Estlands udenrigsminister Sven Mikser ved et uformelt udenrigsministermøde i EU i september 2017

Europa, og flere terrorangreb har hærget europæiske hovedstæder de seneste år. Ligeledes har Præsident Trump understreget det amerikanske krav om, at de europæiske lande tager ansvar for deres egen sikkerhed og bragt usikkerhed om USA's uforbeholdne støtte til NATOs artikel 5.

Derved synes en nærmest 'perfekt storm' at have ramt Europa, hvilket har ansporet EU til at gentænke sin forsvarsog sikkerhedspolitik. Som det står skrevet i EU's nyeste sikkerhedsstrategi, der blev udgivet under en uge efter Storbritanniens beslutning om at melde sig ud af EU, så er 'blød magt ikke længere nok', og det er derfor nødvendigt at 'styrke EU som et sikkerhedsfællesskab, der er pa- rat til at afskrække, svare igen og beskytte sig selv imod eksterne trusler'.

Foruden de eksterne ændringer af Europas sikkerhedspolitiske situation har interne udviklinger også givet yderligere momentum til et styrket EU-forsvarssamarbejde.

Storbritannien har traditionelt været den største modstander af et styrket EU-sikkerheds- og forsvarssamarbejde, og nu, hvor de er på vej ud af unionen, kan de ikke længere blokere tiltag på området.

Brexit har derudover skabt en større politisk opbakning til EU hos de resterende medlemslande, ikke mindst i Tyskland og Frankrig. Storbritanniens beslutning mindede de resterende EU-lande 


\section{Som det står skrevet i EU's nyeste sikkerhedsstrategi, der blev ud- givet under en uge efter Storbritanniens beslutning om at melde sig ud af EU, så er 'blød magt ikke længere nok', og det er derfor nød- vendigt at 'styrke EU som et sikkerhedsfællesskab, der er parat til at afskrække, svare igen og beskytte sig selv imod eksterne trusler'.}

om, at internationale institutioner er noget man kan melde sig ud af, og at selve unionens overlevelse derfor kunne være på spil. For at undgå at Storbritanniens exit skulle starte en dominoeffekt måtte EU-medlemmerne bevise EU-projektets fortsatte relevans.

Den ændrede sikkerhedssituation i Europas nærområde gjorde således, at forsvars- og sikkerhedssamarbejdet blev et område, som de fleste EU-lande kunne se fordelene i at styrke.

\section{Mod en fælles EU-forsvarsunion?}

Efter EU's sikkerhedsstrategi blev udgivet i juni 2016, er hensigtserklæringerne blevet fulgt op af en række konkrete initiativer, der har til formål at samordne EU-landenes militære indsatser og kapaciteter.

Det fik for nylig EU's udenrigschef, Frederica Mogherini, til - ved den årlige konference i Det Europæiske Forsvarsagentur - at erklære, at den gamle drøm om et fælleseuropæisk forsvarssamarbejde er ved at blive til virkelighed: "I dag bygger vi Den Europæiske Union for Forsvars og Sikkerhed. Det er ikke længere en plan, det er ikke en drøm, det er virkelighed. Vores grundlæggeres drøm er endelig ved at gå i opfyldelse."

Det måske mest bemærkelsesværdige nye tiltag er lanceringen af en europæisk forsvarsfond, der skal støtte forskning, indkøb og udvikling af fælles militærkapabiliteter. Fonden drives af Europa-Kommissionen, der råder over EU-budgettet, og som ellers aldrig har været involveret i EU's sikkerheds- og forsvarspolitik, der tidligere var et særskilt, rent mellemstatsligt samarbejde.

Med Forsvarsfonden skal der for første gang bruges penge fra EU's budget til at udvikle en større fælleseuropæisk forsvarsindustri og begrænse problemerne med protektionisme og duplikationer, som har karakteriseret den europæiske forsvarsindustri. Indtil nu har anskaffelse af militære kapabiliteter også foregået på nationalt niveau, men fordelene ved fremover at gøre dette i fællesskab er mange, ikke mindst $\mathrm{i}$ en tid hvor mange EU-medlemslande står over for at skulle indkøbe nye generationer af våbensystemer, som de færreste har råd til at udvikle alene.

Kommissionens forsvarsfond har til formål at motivere EU-landene til at indgå i fælles forsvarsindustriprojekter, der bliver støttet af fonden. Fonden er så småt begyndt at dele penge ud, og hensigten er, at Europa-Kommissionen efter 2020, hvor det nye EU-budget træder i kraft, årligt vil bidrage med én mia. euro til kapabilitetsudvikling og 500 mio. euro til forskning på området.

Ideen er desuden, at Kommissionens bidrag skal udgøre 20 pct. af den samlede fond til udvikling af kababiliteter, mens yderligere 80 pct. af midlerne skal komme fra medlemsstaterne selv.

Selvom der stadig er en lang række ubekendte og ubesvarede spørgsmål, ikke mindst om det rent faktisk vil lykkes Europa-Kommissionen at afsætte 1,5 mia. euro til forsvarsindustrien, er initiativet blevet mødt overraskende positivt af EU's øvrige institutioner, medlemslandene og forsvarsindustrien. 
Hvis fonden lykkes med dens formål, kan det blive en afgørende brik i planen om at styrke Europas forsvarssamarbejde.

\section{PESCO}

Samtidig med forsvarsfondens tilblivelse i sommeren 2017 besluttede EU-landene desuden at gøre brug af en hidtil aldrig anvendt lov-provision i Lissabontraktaten, som gør det muligt for lande, der ønsker det, at indgå i et 'permanent, struktureret samarbejde' om at samordne deres militære indsatser og udvikle kapaciteter. Den oprindelige idé bag PESCO, som dette samarbejde kaldes, var, at de lande, der ønsker at arbejde mere sammen, har mulighed for det, mens de, der ikke er parate, kan springe til senere. Således var PESCO tænkt som en mulighed for at skabe handling på det følsomme forsvarsområde, som EU-landene tidligere har haft svært ved at blive enige om.

I december 2017 blev samarbejdet formelt lanceret af 25 ud af EU's 28 medlemsstater - alle på nær Storbritannien, Malta og Danmark. PESCO er således ikke, som det var tilsigtet i EU-traktaten, blevet en lille, eksklusiv klub af lande, der fører an i tilblivelsen af en Europæisk forsvarsunion, men er i stedet lanceret som et inklusivt samarbejde, hvor alle kan være med.

Dette udfald er resultatet af et tyskfransk kompromis mellem franske ambitioner og et tysk ønske om inklusion. Kompromiset udgøres af en model, hvor de deltagende lande gennem faser vil udvide forsvarssamarbejdet. For at kunne blive en del af PESCO skal de deltagende lande tilslutte sig en række kriterier, bl.a. øge nationale forsvarsbudgetter og sikre samordning af landenes forsvarsplanlægning, som de så lover at leve op til på sigt, frem for at imødekomme kriterierne på forhånd, som ellers var den oprindelige tanke.

Ud over at PESCO skal udgøre en generel ramme for øget koordinering af forsvarspolitik i EU-regi, indebærer initiativet også, at EU-landene skal indgå i samarbejde om konkrete forsvarsprojekter inden for PESCO-rammen. Her behøver alle PESCO-landene ikke at deltage, men det giver mindre grupper af lande mulighed for at udvikle projekter, der er i overensstemmelse med netop deres sikkerheds- og forsvarspolitiske interesser.

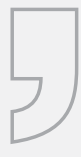
PESCO er således ikke, som det var tilsigtet i EU-traktaten, blevet en lille, eksklusiv klub af lande, der fører an i tilblivelsen af en Europæisk forsvarsunion, men er i stedet lanceret som et inklusivt samarbejde, hvor alle kan være med.

De første 17 projekter, som EU-landene skal i gang med, er allerede blevet lanceret, om end de fleste har lange udsigter. Eksempler på konkrete PESCO-projekter er udviklingen af en ny type kampvogn, et nyt maritimt droneprogram samt en mobil medicinsk kommando-enhed. Denne del af PESCO-samarbejdet læner sig op ad formålet bag EU's forsvarsfond, og selvom sammenhængen mellem initiativerne stadig ikke er endeligt bestemt, er hensigten, at de skal underbygge hinanden. I modsætning til forsvarsfonden er PESCO dog et mellemstatsligt initiativ, hvor medlemslandene selv bærer ansvaret for dens fremdrift og aktiviteter.

At PESCO nu er blevet lanceret i et format, der ligger nærmest den tyske vision om inklusivitet, betyder, at det er et næsten samlet EU, der bevæger sig mod mere forsvarskoordination, men at det 
også er en mindre slagkraftig ramme end den Frankrig - og EU-traktaten - havde tilsigtet. Efter lanceringen af PESCO har Frankrig udgivet et strategisk dokument, der kortlægger en vision for, hvor Frankrig og Europa skal bevæge sig hen militært. Her skitseres en idé om, at man vil lancere en europæisk interventionsstyrke med fælles indsatstropper, der skal gøre det muligt for europæiske lande, der vil og kan, at løse militære opgaver i fællesskab.

Det er uklart om dette initiativ kommer til at ligge inden for EU-rammen, i NATO eller bliver en ny multilateral 'koalition af villige stater', som det kendes fra USA's interventionsstrategi, men det understreger, at der foregår flere sideløbende udviklinger, som alle har til hensigt at styrke Europas forsvars- og sikkerhedsdimension.

\section{Lang vej igen}

Der er stadig lang vej til tilblivelsen af en egentlig europæisk forsvarsunion. Det kommer til at kræve ressourcer, som endnu ikke er sikret; tid, da udviklingerne har lange udsigter; og mest afgørende kommer det til at kræve politisk vilje fra medlemslandene.

Det er også vigtigt at understrege, at konturerne af det fælles forsvarssamarbejde, der nu er ved at tegne sig, er meget anderledes end den gamle føderalistiske drøm fra 1950'erne om en fælleseuropæisk hær. De nye initiativer drives frem af en ad hoc - og med undtagelse af fonden - mellemstatslig proces, som bygger på frivillige bidrag fra de deltagende medlemmer og er fokuseret på at udvikle konkrete militærkapabiliteter, som mange medlemslande kan se praktiske og økonomiske fordele i.

Dermed udgør EU rammen for et øget forsvarssamarbejde, der er fokuseret på udvikling af militærkapabiliteter, og tanken er da også at styrke EU's overordnede evne til at agere forsvars- og sikkerhedspolitisk. Det er dog i sidste ende landene selv, der anskaffer og bruger kapabiliterne, som de ønsker, måtte det være bilateralt, i EU-regi eller i NATO-regi.

Således er det heller ikke sikkert, at det øgede europæisk forsvarssamarbejde alene kommer til at foregå i EU-regi.

\section{Styrket samarbejde}

Ved at fokusere forsvarssamarbejdet på udvikling af fælles militærkapabiliteter, cementeres det også, at EU er ved at bevæge sig ind på et helt nyt område, nemlig varetagelsen af Europas interne sikkerhed, og dermed rykker tættere på det, der er NATOs eksistensgrundlag. Allerede i dag anvendes målet om at beskytte europæiske borgere til at legitimere EU's missioner, herunder 'Operation Sophia' i Middelhavet og EU's engagement i Mali, der beskrives som en del af EU's migrations- og terrorismebekæmpelse snarere end ren altruisme.

Det har derfor også været afgørende for unionen, de deltagende lande og NATO at understrege, at den nuværende proces har til formål at supplere snarere end at udfordre NATO. Et af de mest

Et af de mest fundamentale spørgsmål, der ofte har forhindret EUlandene i at styrke et militært samarbejde i EU-regi, har været frygten for, at det ville duplikere eller udfordre NATO som den primære garant for europæisk sikkerhed og dermed sætte forholdet til USA på spil. 
fundamentale spørgsmål, der ofte har forhindret EU-landene i at styrke et militært samarbejde i EU-regi, har været frygten for, at det ville duplikere eller udfordre NATO som den primære garant for europæisk sikkerhed og dermed sætte forholdet til USA på spil. Da EU fik sin forsvars- og sikkerhedspolitik tilbage i 2003, var det efter en kompromisaftale mellem de to organisationer, der understregede, at NATO fortsat var den primære sikkerhedsinstitution i Europa, og at EU kunne få adgang til NATOs militærudstyr og hovedkvarterer i NATO i de tilfælde, hvor NATO ikke selv ønskede at igangsætte en mission. Denne aftale har dog været brugt begrænset efter en række politiske uenigheder, og samarbejdet mellem de to organisationer har indtil nu været minimalt.

Derfor har man i sommeren 2016 udgivet en fælleserklæring mellem EU og NATO, der siden er fulgt op af flere tiltag, som beskriver visionen om fremover at styrke et strategisk partnerskab mellem NATO og EU, hvad angår kapacitetsopbygning, strategisk beslutningstagen og operationelt samarbejde. Selvom det langt fra er sikkert, at det kommer til at foregå gnidningsfrit, forventes det derfor, at de to organisationer fremover vil knytte tættere bånd i det europæiske sikkerhedssamarbejde.

\section{Danmarks forsvarsforbehold}

Da Danmark fik sit forsvarsforbehold i 1993 efter det danske nej til Maastrichttraktaten året forinden, var det uden praktisk politisk betydning, da der dengang ikke eksisterede et EU-samarbejde på området. Det gjorde det muligt for fortalerne af et forbehold at binde deres kampagne op på frygten for, at EU skulle udvikle en overnational hær, som ville underminere
Danmarks suverænitet og udfordre NATOs prærogativ for Europæisk sikkerhed.

EU fik som bekendt ikke en overnational hær, og forsvarsforbeholdet har derfor ikke beskyttet Danmark mod suverænitetsafgivelse, men i stedet afholdt Danmark fra at deltage i et mellemstatsligt og dermed frivilligt samarbejde. Da EU's sikkerheds- og forsvarspolitik så blev operationaliseret i 2003, kom forbeholdet til at betyde, at Danmark ikke kunne deltage i EU's militære operationer eller i EU's forsvarsagentur. Konsekvenserne var dog overskuelige, da Danmark i stedet har kunnet prioritere sit aktive engagement i NATO samt et stadig tættere bilateralt bånd med Storbritannien og USA.

Men med de nye EU-forsvarsinitiativer, der indikerer skridt mod et nyt forsvars- og sikkerhedssamarbejde, begynder konsekvenserne af det danske forsvarsforbehold at blive en reel udfordring for Danmark. Konkret betyder forbeholdet, at Danmark ikke kan deltage i PESCO samt dele af forsvarsfonden. Danske virksomheder vil formodentlig godt kunne få adgang til dele af fonden, da den styres af Europa-Kommissionen og kommer til at høre under det indre marked, selvom det endnu ikke ligger endeligt fast, hvordan fonden institutionelt bliver forbundet til EU's forsvarspolitiske område.

De sikkerhedspolitiske udfordringer, som forbeholdet skaber i takt med lanceringen af de nye EU-initiativer, anerkendes i Danmarks nye udenrigspolitiske strategi fra 2017, hvor det noteres, at "konsekvenserne for Danmark af forsvarsforbeholdet vil blive endnu tydeligere og understreger, at udviklingen på området er en helt anden, end den man fra dansk side vendte sig imod i 1992". Det sagt, støtter den danske regering EU's nye tiltag, ligesom et stort flertal i befolkningen 
ønsker, at Danmark skal deltage i mere EU sikkerheds- og forsvarssamarbejde.

\section{Ikke 'business as usual'}

Det får således politiske og økonomiske konsekvenser for Danmark ikke at kunne tage del i det praktiske samarbejde om at harmonisere forsvarsindustrien og få del i fordelene ved at pulje våbenindkøb og indgå i udviklingen af nye våben. Men en mere fundamental udfordring ved at stå uden for en proces, hvor EU-landene rykker tættere på hinanden, er, at Danmark ikke ligeså let kan basere sin sikkerhedspolitik på Storbritannien og USA som tidligere og må gentænke sine alliancepartnere.

Med Brexit mister Danmark sin vigtigste partner i EU-kredsen, der har promoveret interesser i overensstemmelse med Danmarks, herunder nødvendigheden af et stærkt transatlantisk forhold mellem EU og USA/NATO. Denne rolle kan Storbritannien naturligvis ikke spille i samme omfang uden for EU, og den britiske regering vil desuden skulle bruge en stor del af sine ressourcer på at forhandle Brexit i de kommende år.

\section{Med Brexit mister Danmark sin vigtigste partner i EU-kred- sen, der har promoveret interesser i overensstemmelse med Danmarks, herunder nødvendigheden af et stærkt transatlantisk forhold mellem EU og USA/NATO.}

Storbritannien er derfor en betydeligt mindre attraktiv partner at lægge sig i slipstrømmen af end tidligere. Desuden har May-regeringen udtrykt ønske om, at Storbritannien kan deltage i EU's forsvarssamarbejde efter landets udmeldelse af EU og således lave en 'omvendt Danmark', som den britiske Professor, Richard Whitmann, har udtrykt det. Hvis det lykkes, vil heller ikke Storbritannien være afskåret fra deltagelse, og Danmark vil på området stå alene uden for EU-samarbejdet.

Hvad angår forholdet til USA, er den amerikanske interesse i den europæiske sikkerhedsarkitektur over en længere periode dalet. Udviklingen er eskaleret under Præsident Trump, der ved at så tvivl om NATO-alliancens ukrænkelighed og kritisere EU-samarbejdet har bidraget til større usikkerhed og skepsis i det transatlantiske forhold.

Også det tættere strategiske partnerskab mellem EU og NATO kan potentielt føre til, at det danske EU-forbehold i fremtiden kan få konsekvenser for Danmarks position i NATO. Danmark kan blive anset som en mindre attraktiv partner, der som det eneste NATO-medlem har behov for at lave en skarp adskillelse mellem de to organisationer og ikke kan være med i fælles EU-NATO aktiviteter.

Her kan man muligvis skabe ad hoc løsninger, hvor man finder en praktisk måde at indgå i dele af samarbejdet, men det vil kræve ressourcer og politisk kapital, der kunne være brugt andetsteds. Indenrigspolitisk kan en sådan tilgang også vække modstand, da man i forsøget på at finde smuthuller, der muliggør deltagelse, kan komme ud i juridiske gråzoner i implementeringen af forbeholdet.

\section{Vejen frem for Danmark}

Vigtigheden af at fastholde USA's støtte til NATO vil naturligvis forblive et afgørende sikkerhedspolitisk mål for Danmark, og man skal heller ikke undervurdere, at der stadig er lang vej til europæisk autonomi på området. Men når USA's udenrigspolitiske kurs, Brexit og et forværret trusselsbillede omkring Europas grænser 
medfører, at de fleste EU-lande nu ønsker en hidtil ukendt grad af europæisk militært samarbejde, er Europa inde i en sikkerhedspolitisk udvikling, hvor Danmark må tage stilling til sin sikkerhedspolitik på et mere grundlæggende niveau.

I Danmarks udenrigspolitiske strategi noteres det også, at man efter Brexit har tænkt sig at udbygge samarbejdet med traditionelle partnere og søge nye alliancepartnere, der deler interesser og værdier med Danmark. Siden da har udenrigsminister Anders Samuelsen været på rundrejse i europæiske hovedstæder for at finde nye allierede på de områder, der kan hjælpe med at promovere delte interesser i EU.

Det er fornuftigt, at udenrigsministeren søger nye alliancepartnere blandt ligesindede europæiske lande, selvom alliancer med andre mindre europæiske stater ikke ændrer ved det grundvilkår, at Tyskland og Frankrig er de eneste tilbageværende EU-medlemmer med nok tyngde til at lede det europæiske sikkerhedssam- arbejde. Hvis præsident Emmanuel Macrons tiltag om en europæisk interventionsstyrke ser dagens lys, og det bliver uden for EU-rammen, kunne det åbne en ny mulighed for dansk sikkerhedspolitik, der kan supplere samarbejdet med Storbritannien og USA.

Den europæiske sikkerhedsarkitektur er i forandring. En større del af det sikkerheds- og forsvarspolitiske samarbejde foregår i EU under fransk-tysk lederskab, Storbritanniens rolle i den europæiske sikkerhedsarkitektur bliver mindre, og den transatlantiske kløft bliver større. Hvis Danmark ikke finder svar på, hvordan man vil håndtere disse udviklinger, risikerer man gradvist at miste indflydelse og status på det sikkerhedspolitiske område og blive mere isoleret $\mathrm{i}$ en periode, hvor den sikkerhedspolitiske situation er sværere og mere omskiftelig end på noget andet tidspunkt efter den kolde krigs afslutning. 


\section{Danskerne og Rusland: Der plejer ikke at blive} krig

Af Michael Hesselholt Clemmesen

Den dominerende danske opfattelse af truslen fra Rusland mod NATO-lande i Nordeuropa og det tilhørende konfliktscenarie er som følger: Putin har for at bevare magten valgt at satse på en gammeldags macho-markerende anvendelse af Ruslands begrænsede militære midler. Med trusler og misinformation søger han at intimidere og splitte NATO for at genetablere Ruslands retmæssige placering blandt verdens stormagter. Men da han er rationel, ved han, at det ville være katastrofalt for hans land, hvis han faktisk åbent angreb et NATO-land, fordi NATO samlet er så meget stærkere end Rusland.

Hvis det helt usandsynlige alligevel skulle ske, og Rusland invaderede Baltikum, vil baglandet Danmark ikke blive ramt direkte af andet end cyberangreb samt måske nogle konventionelle missiler fra Kaliningrad.

Danmarks bidrag i den usandsynlige situation vil blot være sikringen af vo- res territorium som base samt hele den lille danske felthærsrest, der så jævnfør regeringens udkast til forsvarsforlig kan opbygges på seks måneder. Mere kan man ikke forlange af vores lille land. Heller ikke hvis forventningen om en 'happy ending' for Vesten i krigen mod Rusland skulle vise sig for optimistisk. Vi plejer jo til sidst at blive reddet af venlige landes indsats uden væsentlig egen indsats.

Uanset at civile og uniformerede danske eksperter står bag denne mening, er den desværre overfladisk og grundfalsk.

\section{Ruslands styrke}

De danske og udenlandske analytikere, der følger den russiske militære udvikling tæt, konstaterer, at Rusland i løbet af de sidste 25 år og især siden 2008 gennem målbevist satsning ikke alene har nået amerikansk teknologisk niveau på centrale områder for styrkebalancen. Man har på væsentlige felter opnået klar overlegenhed, og i Østukraine og Syrien er dette delvis blevet testet og demonstreret.

Michael Hesselholt Clemmesen er pensioneret brigadegeneral og seniorforsker [emeritus] ved Forsvarsakademiets Institut for Militærhistorie og Krigsteori. Hans tjeneste i Forsvaret omfattede to år på Bornholm og blev afsluttet med ti år i Baltikum. Han har i næsten fyrre år været aktiv som kritisk sikkerhedspolitisk kommentator og strategihistorisk forsker og forfatter. 


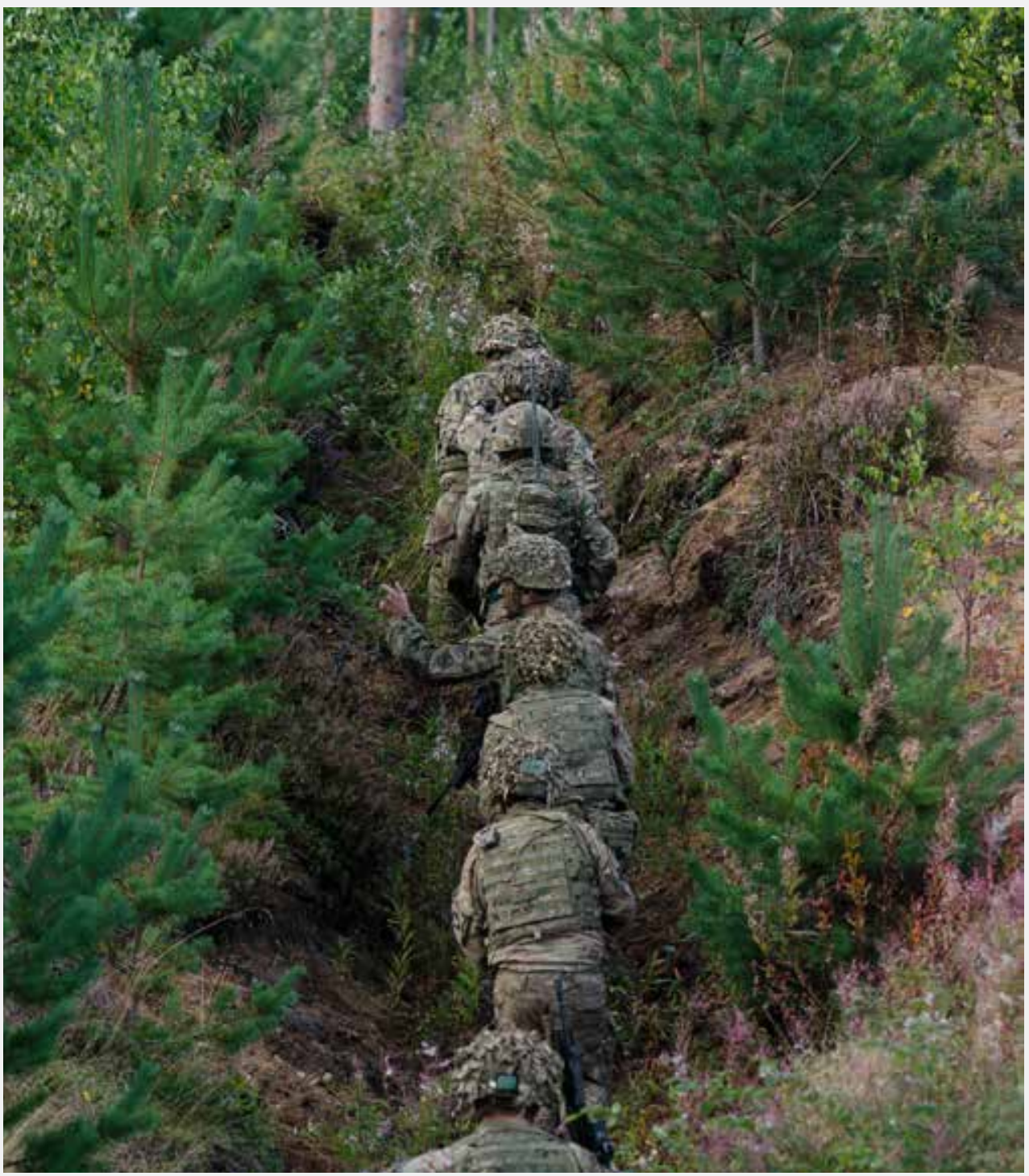

FOTO: LCpl Craig Williams via wikimedia commons

Britiske tropper på øvelse i Estland som led i NATOs fremskudte tilstedeværelse 
For de baltiske lande, Danmark og andre lande i Østersøområdet er det væsentligt, at Rusland har opnået overlegenhed med hensyn til luftværnsmissilsystemer, og afgørende, at man nu har langtrækkende sømålsmissiler, som Vestens flåder ikke har forsvarsvåben mod. De er bl.a. placeret på samme type lastvogne, der anvendes til langtrækkende krydsermissiler og ballistiske missiler, der kan være kernevåbenbærende.

Alle disse missiltyper er placeret fremskudt i Kaliningradprovinsen på trods af, at de her er direkte truet af den nu planlagte polske anskaffelse af amerikanske PATRIOT-luftværnsmissiler og HIMARS-raketartilleri.

\section{Russiske krigsforberedelser ligger fortsat helt i hænderne på en elite af veluddannede generalstabsofficerer med en igennem 150 àr udviklet, klassisk 'militærvidenskabelig' opfattelse.}

Et andet forhold, der nok er umuligt for de mange militært ukyndige vestlige eksperter at forstå, er, at russiske krigsforberedelser fortsat ligger helt i hænderne på en elite af veluddannede generalstabsofficerer med en igennem 150 år udviklet, klassisk 'militærvidenskabelig' opfattelse.

Den mulige konflikt analyseres for at skabe et godt doktringrundlag for opportunistisk udnyttelse af svaghed og blottelser. Forskellige handlemuligheder gennemtænkes og simuleres som af en dygtig skakspiller. Når egne svagheder erkendes i krigsspil eller de store, tilbagevendende krigsplansøvelser som ZAPAD 2017, tilpasses planlægning og de militære enheder hurtigt. Man er i modsætning til i Vesten akut bevidst om egne svaghe- der men tror alligevel, at der findes militære løsninger, hvis man dristigt og hensynsløst udnytter mulighederne. I Syrien fik de ret.

I Vesten domineres den sikkerhedspolitiske debat af teoretiske statskundskabsfolk med en arrogant afvisende holdning til bl.a. militær ekspertise og erfaring, som de finder anakronistisk, fordi de a priori ved, at gammeldags krige aldrig vil ske igen. Som det internationale diplomati til midt-juli 1914 ved de, at storkrig er ulogisk og derfor utænkelig.

\section{En Potemkin-landsby i forfald}

Jeg må chokere læserne med straks at understrege, at ingen hær har nogen som helst værdi i kamp eller til afskrækkelse af en kvalificeret modstander, hvis officerskorpset i en menneskealder ikke har fundet det relevant at tænke på, diskutere og realistisk øve storkrig og har afskaffet den nødvendige krigslogistik samt evnen til ligeværdig elektronisk krigsførelse.

Uanset hvor mange penge, der anvendes til at aflønne store afprofessionaliserede kadrer og deres kontraktsoldater, vil resultatet, hvis de møder virkeligheden, blive, som da asiatiske fyrsters moderne bevæbnede hære blev udslettet af europæisk kommanderede og disciplinerede styrker for 180-130 år siden.

Når man i diskussionen her i landet omtaler NATO, er det uanalytisk, ukritisk og uden ønske om at forstå ubehagelige realiteter. Som jeg for 30 år siden beskrev i Udenrigs (nr. 2, 1988) opfattes Alliancen som danskernes sikkerhedspolitiske Folkekirke, som vi forudsætter virker, når vi har brug for den.

Med NATO menes reelt USA, og vi gør os blinde for de siden 1990 gradvise amerikanske styrkereduktioner og materielnedslidning. Vi overser landets 


\section{Vi ignorerer også USA's demonstrerede manglende evne siden 1991 til at fastlægge og fastholde en realistisk strategi for anvendelse af sine og allieredes militære magtmidler.}

manglende økonomiske evne til at bevare mere end en begrænset del af dets militære styrke, og ignorerer det forhold, at USA på grund af forpligtelser i Asien og Stillehavet ikke kan gøre ret meget mere i Europa end nu, slet ikke uden et meget langt varsel. Vi ignorerer også USA's demonstrerede manglende evne siden 1991 til at fastlægge og fastholde en realistisk strategi for anvendelse af sine og allieredes militære magtmidler.

Fra begyndelsen af nullerne overbeviste vesteuropæiske NATO-lande sig om, at den del af historien, der indebar traditionelle krige i Europa, var slut. Fremtidens problem var reduceret til fjerne 'nye krige', og kun de gamle kolonimagter Frankrig og Storbritannien bevarede indtil besparelser nu små kapable ekspeditionsstyrker.

Samtidig omskabte de kontinentaleuropæiske medlemmer deres militære styrker til overbureaukratiserede hobbyklubber med meget store underbeskæftigede officerskorps med størst mulig jobsikkerhed og mindst mulig kritisk diskurs. Specielt i disse hære, med Bundesheer og den danske hær i front, blev de få generelle militære øvelser til drejebogstyrede rutineaktiviteter, hvis uddannelsesværdi også blev undergravet af arbejdstidsbestemmelser, arbejdsmiljø- og sikkerhedsrammen.

Logistik og støttefunktioner blev af liberale ideologiske modeårsager udliciteret, så de aldrig vil være til rådighed i krig. Dette sammen med afskaffelsen af de realistiske militære øvelser, nedbygningen af lagre af ammunition og reservedele, opløsning af reserveenheder samt hærofficerskorpsenes manglende intellektuelle energi og tro på egen relevans undergravede meget hurtigt hærenes evne til at gennemføre andet end symbolsk militær tilstedeværelse. Skulle de møde en kompetent modstander i højintensive kampoperationer, skal deres overlevelsestid tælles i timer.

Heldigvis ved de civile militæreksperter, at der aldrig bliver krig i Europa. Denne viden fik NATO til at forklare de østeuropæiske lande, herunder balterne, at medlemskab af Alliancen forudsatte, at de opgav ideen om territorialforsvar med dens værnepligt og reserver, panserværnsvåben og totalforsvarslogistik.

Mens de østeuropæiske lande efter opvågnen til den nye realitet siden 2014 forsøger at udbedre skaderne, er der ingen reelle tegn på, at de kontinentaleuropæiske medlemslande, herunder Danmark, vil gøre deres hære til andet end små puljer af mandskab og materiel til symbolsk grænsetilstedeværelse og små rutineøvelser inden for arbejdstiden. Når der aldrig igen bliver krig i Europa, er dette uproblematisk.

\section{Hvordan krige starter}

Forsvarets Efterretningstjeneste synes på grund af sine uanalytiske forudsætninger om NATOs styrke at udelukke muligheden for et russisk kupforsøg mod Baltikum, fordi dette, føler man, ville være irrationelt. Tjenesten antager, at krige vælges på grundlag af rationel analyse af muligheder og konsekvenser. Det er der desværre ikke noget historisk fundament for at tro.

Krigsmuligheden blev valgt som den 
mindst ringe mulighed bl.a. i 1863 af Danmark, i 1904 af Rusland, i 1914 af Østrig-Ungarn, i 1941 af først Tyskland mod Sovjetunionen og så Japan mod USA, i 1964 af USA i Vietnam, i 1979 af Sovjetunionen og i 2003 af USA. Det skete normalt i en kombination af tilfældigheder, egocentrisk fejllæsning af modstanderen, indenrigspolitisk tunnelsyn samt svigtende krav om professionel militær analyse med undervurdering af risici og oppustet opfattelse af egen styrke.

Lad os alligevel forudsætte, at en fremtidig russisk beslutning om at tage kontrol med Baltikum sker rationelt. Et forsøg er rationelt, hvis NATO ikke har rimeligt troværdige svar på russiske handlemuligheder. Kommer Rusland med et tilforladeligt 'fredstilbud', når de på et par uger har nået deres mål i Baltikum og måske også det østlige Polen, så stopper krigshandlingerne med en objektivt bedre russisk position til følge.

Et sådant forløb vil kunne ses som rationelt, fordi NATO i mange måneder nok flere år - ikke vil have styrker til en generobring af det tabte; fordi der ved en fortsættelse af krigen vil være akut risiko for en optrapning til kernevåbenanvendelse, hvilket Rusland vil understrege; fordi der ikke vil være enighed i Alliancen; og fordi USA's position indtil videre undergraves af landets ledelse.

Et sidste problem med den danske normalopfattelse er, at den ser på situationen i Europa isoleret. Uanset om en konfrontation indledes i Asien eller i Europa vil den skabe risiko for opportunistisk udnyttelse af situationen i den anden verdensdel. Som i Anden Verdenskrig er Asien og Europa knyttet sammen, og med USA's relative svækkelse vil fx en optrapning i Korea skabe en akut risiko i Europa. Udløseren af russisk handling over for Baltikum kan komme i Asien eller USA selv.

\section{Baltikum}

NATOs situation i Østersøområdet er nu præget af kombinationen af to næsten uløselige svagheder: For det første Alliancens meget lange landegrænse, der af hensyn til afskrækkelse skal kunne forsvares i mange uger måske måneder, indtil nordamerikansk hjælp kan nå frem. For det andet sårbarheden af søruterne i den sydlige Østersø.

Den klassiske tommelfingerregel, at en forsvarer kun behøver en tredjedel af angriberens styrke, er meningsløs i en situation med lav troppetæthed, specielt hvor forsvarets dybde er begrænset, og angriberen af politiske grunde har initiativet.

Den samlede baltiske landgrænse til Rusland og Hviderusland opgives til $1.660 \mathrm{~km}$, heraf mere end $800 \mathrm{~km}$ direkte til Rusland. Det er over $300 \mathrm{~km}$ længere end den finsk-russiske grænse, og den baltiske geografis forsvarsdybde og forsvarsværdi er betydeligt mindre end den finske. Ud over landgrænsen skal også den estiske nordkyst og landets øer, den sydlige litauisk-lettiske østersøkyst samt hovedstæderne og de primære havne sikres. Af landgrænsernes totale længde skønnes mellem 200 og $250 \mathrm{~km}$ at skulle gives et egentligt forsvar på grund af vejnettet eller kort afstand til hovedstæder, havne eller lufthavne.

I typisk baltisk grænseterræn vil selv en balanceret, moderne defensivt udrustet brigade, der kender området, har øvet i dette og forberedt forsvaret, ikke kunne forsvare mere end 10-12 km i bredden.

Forsvaret af de specielt truede ruter og afsnit i de tre baltiske lande ville derfor samlet kræve værdien af omkring 20 øve- 


\section{Balterne skulle alene stille småstyrker som solidaritetsmarkører i Allian- cens og USA's småkrige i fjerne lande. Balterne råder derfor i modsæt- ning til finnerne ikke over 900.000 uddannede reservister bag felthærs- brigaderne og evnen til om nødvendigt at forøge brigadernes antal.}

de brigader. Da disse så er disponeret, skal resten af grænsen samt truede kyster sikres af mindre stærke, hjemmeværnslignende lokalforsvarsenheder, der bakkes op af vel to mobile brigader per land.

For at opsummere den landmilitære dimension: Det minimale samlede styrkebehov for at kunne forsvare de tre baltiske lande er omkring 25-30 brigader, samlet 120.000 til 150.000 soldater. Hertil mindst yderligere 80.000 til 120.000 soldater i logistik, stabe og anden støtte fordelt mellem de baltiske lande og andre NATO-lande med styrker i Baltikum. Hvert baltisk land skal finde yderligere 20.000 til 50.000 lokalforsvarssoldater. Forsvaret af Baltikum mod Rusland kræver altså samlet set omkring 250.000 soldater og 100.000 hjemmeværnsfolk.

Dette antal svarer nogenlunde til det antal Sverige kunne mobilisere under den kolde krig, og som Finland fortsat har på dages til ugers beredskab. Med andre ord kunne det direkte baltiske forsvarsproblem teoretisk løses som det finske, der med et forsvarsbudget, der svarer til det danske, med 230.000 soldater i front og yderligere 500.000 lokalforsvarsstyrker realistisk gør et russisk lynangreb meget risikabelt og et velforberedt russisk angreb ekstremt bekosteligt.

Også NATO-lande kunne som tidligere udskrive civilt materiel til enhederne og have uddannede kadrer og mandskab til at møde på 24-48 timer, men så skulle man indse og forklare, at historien ikke er slut.

Af det skitserede styrkebehov vil balterne om nogle år maksimalt kunne dække en fjerdedel, da de mangler materiel og uddannede kadrer og personel til mere. Dette også på grund af den beskrevne anakronistiske NATO-rådgivning for tyve år siden mod værnepligt og samfundsforankret territorialforsvar.

Balterne skulle alene stille småstyrker som solidaritetsmarkører i Alliancens og USA’s småkrige i fjerne lande. Balterne råder derfor i modsætning til finnerne ikke over 900.000 uddannede reservister bag felthærsbrigaderne og evnen til om nødvendigt at forøge brigadernes antal. Det resterende behov, omkring 20 brigader, må derfor dækkes af allierede styrker, der i alt væsentligt må ankomme og støttes ad søvejen. Transport over landegrænsen fra Polen er ikke sikker og lufttransport kan kun levere lette enheder til kortvarig indsats uden logistik.

\section{Østersøen og Bornholms rolle}

Mulighederne, for at NATO kan støtte Baltikum ad søvejen i en krise og konflikt med Rusland, afhænger af, om skibskonvojer kan sikres mod truslen fra miner, ubådstorpedoer samt og ikke mindst sømålsmissiler affyret fra skibe, fly samt lastvogne og raketbatterier skjult $i$ anonyme skibscontainere på skibe og i land.

Den største trussel mod NATOs mulighed for at sejle i Østersøen er de moderne BASTION-sømålsmissilbatterier i Kaliningrad, der ikke kan sættes ud af spillet, dels fordi det forudsætter en optrapning til angreb på russisk jord, dels fordi det er vanskeligt at finde og med sikkerhed identificere raketbatterierne og dette helst uden at forveksle dem med måske kernevåbenudrustede ISKANDER-missiler. 
For at NATO kan udnytte søruterne i Østersøen kræver det en fase med forudgående angreb med fly på Kaliningrad og ikke mindst bekæmpelse af raketbatterierne fra Polen og Litauen med kanoner samt de langtrækkende våbensystemer, som Polen nu køber til flyvevåbnet og hæren.

\section{At satse på, at de russiske militære planlæggere ikke kan se den direkte og tætte sammenhæng mellem sikring af Baltikum og den danske ø Bornholm er ikke kun naivt, men amatøragtigt.}

Kaliningrads geografisk isolerede situation gør det indlysende vanskeligt for Rusland at opnå en varig blokering af vestlig anvendelse af søruterne. Derfor presses Rusland af de igangværende NATO-forsvarsskridt til at skaffe sig mindre sårbare placeringer for dets missilbatterier. Tre muligheder herfor tegner sig, den estiske ø Saaremaa, Gotland samt Bornholm.

Kuperobring af det sydlige Gotland eller specielt Bornholm tidligt i konflikten vil give Rusland sikrede baser for landets mange og effektive missilsystemer, hvor NATO ingen modtræk har. Især er Bornholm blevet mere attraktiv, da øen i modsætning til Gotland og Saaremaa dels er uforsvaret, dels kan besættes uden de negative virkninger af en operation mod Gotland, der med sikkerhed vil bringe Sverige ud at neutraliteten og udløse den igen forberedte amerikanske flydeployering til svenske flyvepladser.

\section{Efterretningstjenestens uansvarlighed}

At satse på, at de russiske militære planlæggere ikke kan se den direkte og tætte sammenhæng mellem sikring af Baltikum og den danske ø Bornholm er ikke kun naivt, men amatøragtigt.

Traditionelt anvendte efterretningstjenester ordet 'mulighed' i diskussionen af truslerne og gav ved sin tilknyttede analyse de politiske og militære beslutningstagere en central del af grundlaget for at beslutte eller afvente. Denne tilgang markerede den realitet, at efterretningstjenester ikke kunne eller burde tage ansvaret for de politisk ansvarlige og militært operative myndigheders anvendelse af dens vurderinger.

Den tidligere velbegrundede forsigtighed med at træffe beslutninger på vegne af de ansvarlige er nu fortid. Forsvarets Efterretningstjeneste skrev i 2016 i overensstemmelse med ny praksis: "Rusland vil ikke tage politiske og militære initiativer, som ledelsen vurderer, har en høj risiko for at kunne føre til en direkte militær konfrontation med NATO. Det er derfor usandsynligt, at Rusland vil foretage et militært angreb på de tre baltiske lande" (FE, Efterretningsmæssig Risikovurdering 1.12.2016, p. 12).

Ved at sælge forudsigelser som sikkert beslutningsgrundlag og anvende sandsynligheder går man langt videre, idet man reelt lader som om, at efterretningstjenester har kompetence til at tage ansvaret. Reelt lader man som om, at tjenesten kan tage ansvaret fra politikere og de operativt ansvarlige med observationer, hvis fundament er forventningen om, at alle politiske beslutninger er logiske og lineære, som i det konkrete tilfælde blot er en arrogant fastlæggelse af, at det ikke plejer at gå galt.

Tjenester anlægger denne tilgang i en tid, der domineres af brud med, hvad der plejer af ske, bl.a. ved migrationsbølger, britiske folkeafstemninger, amerikanske valg, Tyrkiets halve brud med NATO, 
udfaldet af den syriske borgerkrig og den chokerende udvikling i Nordkoreas militære kapacitet.

Ved at gå fra 'mulighed' til 'sandsynlighed' på et grundlag af ren situationsfremskrivning fritager efterretningstjenester beslutningstagerne for ansvarlighed, men uden selv at kunne påtage sig denne, hvis man ikke overlever til en eventuel efterkrigskommission.

Det er klart, at Forsvarets Efterretningstjeneste med sit nu demilitariserede organisatoriske fokus reelt er en udlandsefterretningstjeneste, der af indenrigspolitisk bekvemmelighed fortsat er finansieret af forsvarsministeriet. Tjenesten har i dette forløb fravalgt evnen til militærfaglig vurdering af et land som Rusland, der af - for vesteuropæere - uforståelige årsager har valgt at lade sin udenrigspolitik styre af en anakronistisk militærvidenskabelig logik.

Udviklingen understreges af, at tjenestens centrale rapporter ikke længere formelt er forsvarschefens ansvar. Som den øverste militære chef havde han tidligere det væsentlige ansvar at koble analyser af truslen sammen med en professionel dybdeforståelse af egen sides styrke og svagheder, som truslen var rettet mod. Hvordan dette kunne og burde ske, blev illustreret under Forsvarskommissionen af 1988's udredningsarbejde. Denne rolle er ikke længere placeret hos den me- get rutinerede forvalter i stillingen, og det er uklart om nogen fagperson længere har ansvaret og derfor også skal opretholde viden om en større krigs krav til forsvaret.

Forsvarets Efterretningstjenestes anvendelse af ordet 'risiko' som en substitut for mulig trussel sker overfladisk, dvs. at man undlader en grundig analyse af hvordan Danmark konkret vil blive ramt/påvirket, så man kan skabe fundamentet for forsvarstiltag. Dette er nok årsagen til, at Danmark i modsætning til Sverige ikke forstår de konkrete russiske behov for $\mathrm{i}$ en sikkerhedspolitisk krise at 'låne' vores strategisk beliggende $\emptyset$ i Østersøen.

Det nu næsten fraværende militære element må være grunden til, at risikovurderingens diskussion af cybertruslen fokuserer på cyberspionage og -kriminalitet snarere end på det russiske totalangreb på centrale dele af den danske finansielle, transportmæssige og sundhedsmæssige it-infrastruktur, som efter erfaringerne fra Ukraine vil kunne ramme Danmark i en krise. Det er forståeligt, at nationalbankdirektøren for nyligt i Berlingske Tidende gjorde sin nervøsitet for et cyberangreb på bl.a. Nets klar.

Danmark spiller ligesom NATOs flertal ludo, hvor intet kan forudses, og ingen kan ansvarliggøres for udfaldet, mens Rusland spiller skak. 


\section{Sikkerhed i en digital tidsalder?}

\section{Af Niels Byrjalsen og Kristian Søby Kristensen}

Det er svært at spå, især om fremtiden. Det må efterhånden være gået op for både meteorologer, meningsmålingsinstitutter og militæreksperter. Alligevel er der god grund til, at Forsvarets Efterretningstjeneste (FE) - med sit unikke mandat og sin særlige kapacitet - årligt skitserer, hvordan det sikkerhedspolitiske landskab vil udvikle sig.

Man kan ikke umiddelbart anklage FE for overvældende nytænkning i arbejdet med den seneste risikovurdering fra december 2017. Ved første øjekast ligner vurderingen fra 2017 mest af alt en kopi af vurderingen fra 2016. Der er igen noget om cybertruslen, terrorisme, Rusland, Kina, Mellemøsten, Afrika, Arktis og Afghanistan. Det eneste nye element er, at Nordkorea har erstattet spredning af masseødelæggelsesvåben som afsluttende tema - og det er jo på sin vis to sider af samme sag. Det ligner stort set gammel vin på gamle flasker. Men djævlen ligger som bekendt i detaljen.

Særligt to detaljer er bemærkelsesværdige. For det første er det vigtigt at notere, at cybertruslen har overtaget 'dukseplad- sen' fra Rusland og behandles i risikovurderingens første kapitel. Denne centrale placering er ikke tilfældig. Cybertruslen er ikke nødvendigvis den største trussel i almindelig forstand, men det er det område, hvor manglen på svar er størst, både i Danmark og internationalt. For det andet er det interessant, at cybertruslen og Rusland opfattes som separate udfordringer, på trods af at Rusland i dansk øjemed er den klart væsentligste aktør på cyberområdet.

Sammen fortæller de to detaljer en mere generel historie om udviklingen i det danske trusselsbillede i de seneste år; en erkendelse af vigtigheden af både cybertruslen og Rusland for dansk sikkerhed, men også en insisteren på at se, forstå og behandle de to som noget forskelligt. Der er ingen tvivl om, at cyberområdet er noget nyt og distinkt. Alligevel kan man spørge, om dette nye ikke bør debatteres, forstås og håndteres som en del af en bredere sikkerhedspolitisk og samfundsmæssig udvikling.

Det nye sikkerhedspolitiske puslespil Siden 2014 har Danmarks sikkerhedspo-

Niels Byrjalsen er videnskabelig assistent på Center for Militære Studier, Institut for Statskundskab, Københavns Universitet.

Kristian Søby Kristensen er vicecenterleder på Center for Militære Studier, Institut for Statskundskab, Københavns Universitet. Han har bidraget til adskillige bøger og skrevet en lang række artikler om forsvars- og sikkerhedspolitik. 


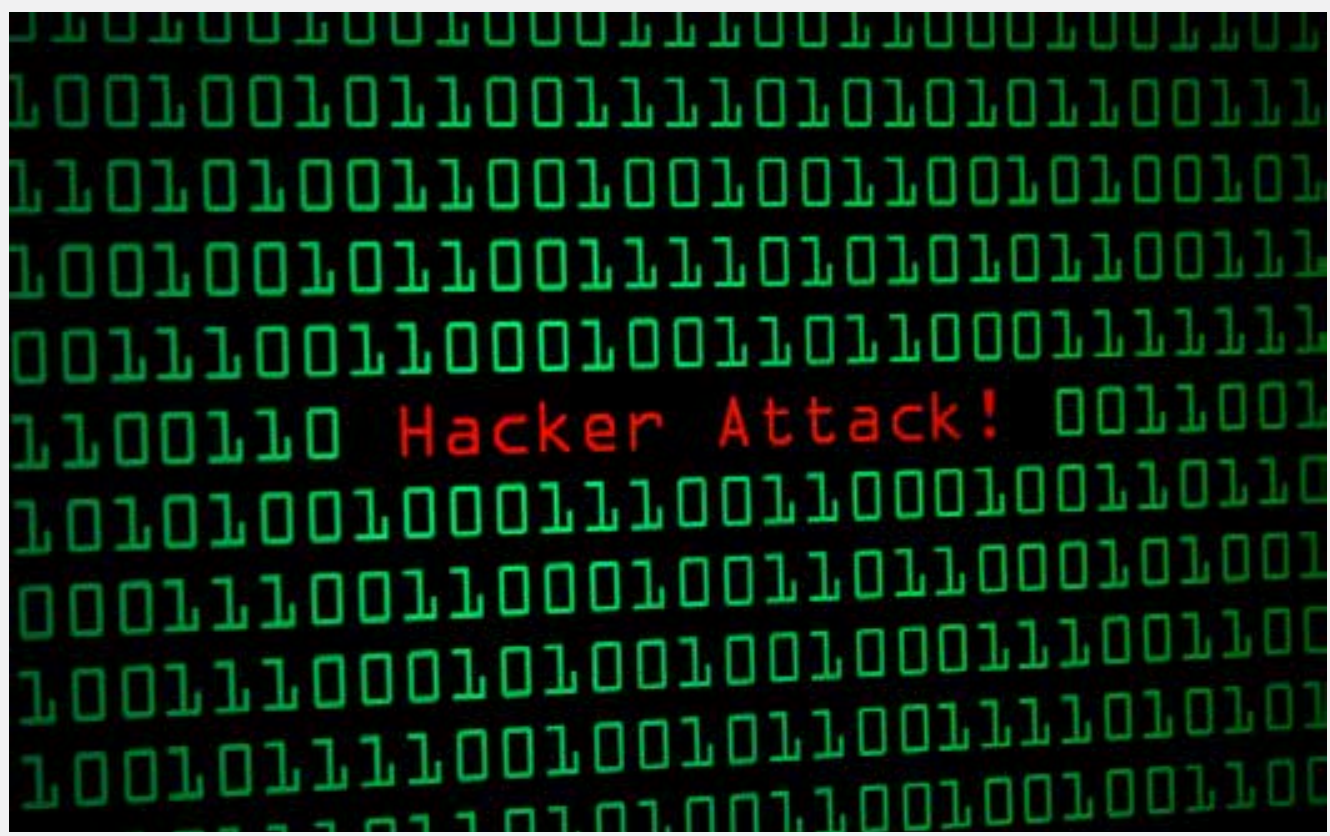

FOTO: Bysayhanla via Wikimedia Commons

litiske situation været præget af konflikten mellem Rusland og Vesten. Selvom konflikten har en klar militær dimension, er den kendetegnet ved en politisk logik. Det russiske regime søger at svække sammenholdet mellem de vestlige lande og tiltroen til det liberale demokrati som et legitimt og funktionsdygtigt politisk system. Det er i denne forbindelse blevet tydeligt - også for efterretningstjenesten - at nye digitale muligheder giver bl.a. Rusland et sæt af effektive værktøjer, som nemt kan udnyttes over for de åbne, demokratiske samfund i Vesten.

Det forøgede fokus på cybertruslen hænger delvist sammen med, at de vestlige lande langt hen ad vejen har besvaret den fornyede konventionelle trussel fra Rusland. I forlængelse af den russiske annektering af Krim i 2014 har NATO iværksat en række tiltag, der skal forsikre alliancepartnere i Ruslands nærområde og afskrække yderligere russisk aggression. Det gælder bl.a. alliancens fremskudte tilstedeværelse i Baltikum og Polen. Derudover har NATO forstærket sine reaktionsstyrker og skruet op for øvelser og aktiviteter i de central- og østeuropæiske lande. Endelig har USA, uden for NATO-regi, forøget sin militære tilstedeværelse i Europa betydeligt.

Den stigende opmærksomhed på cybertruslen er også et udtryk for, at der er tale om en besværlig udfordring, der kræver nye svar. Konventionel afskrækkelse er den nemme og ligefremme del - cybertruslen er vanskeligere og mere kompleks. Udviklingen rejser vigtige spørgsmål for de kommende års sikkerhedspolitiske debat.

\section{Cyber i gråzonen}

I første omgang er det centralt at afklare, hvorfor cyberområdet er så væsentligt 


\section{USA og andre vestlige stater har overvurderet risikoen for, at angreb fører til en 'cyberkatastrofe', men har undervurderet betydningen af cy- bertruslen i forbindelse med påvirkningskampagner i de åbne samfund.}

og vanskeligt at få greb om. Dette skal ses i lyset af den voksende sikkerhedspolitiske betydning, som gråzonekonflikter og informationskrigsførelse tillægges.

Mange internationale konflikter foregår i dag i gråzonen mellem politiske og militære dynamikker. Her kan stater udnytte uklarheder i internationale normer om magtanvendelse over for andre stater. Det sker særligt ved hjælp af midler og metoder og på områder, hvor krigens love ikke nødvendigvis skærer spillereglerne ud i pap - eller hvor de benyttede midler og metoder slører magtanvendelsen så effektivt, at den bliver et fait accompli, inden det internationale samfund når at reagere. Ruslands annektering af Krim er det mest fremtrædende eksempel.

I gråzonekonflikter er digitale værktøjer centrale virkemidler. De er yderst anvendelige i forhold til at operere under det, der almindeligvis opfattes som tærsklen for magtanvendelse i international politik. Det skyldes først og fremmest, at det er meget sjældent, at personer kommer til skade som direkte konsekvens af cyberangreb.

Cyberangreb kan dog stadig have destruktive eller destabiliserende effekter. I takt med at offentlige myndigheder, finansielle systemer, energileverandører og andre bliver mere afhængige af digital infrastruktur, øges sårbarheden over for hacking. Det russiske cyberangreb på den ukrainske energiforsyning i december 2015 er et tydeligt eksempel på denne sårbarhed. Selvom angrebet var kortvarigt, sendte det et kraftigt signal til Ukraine om, at Rusland kan spille med cybermusklerne i den sikkerhedspolitiske gråzone.

I Danmark omfatter eksemplerne det russiske hack af forsvarets mailsystem i 2015-2016 samt angrebet på tre centrale ministeriers hjemmesider i september 2017, der ifølge FE formentlig blev foretaget af tyrkiske cyberaktivister. For nylig kom det desuden frem, at russiske hackere ifølge CIA stod bag angrebet NotPetya, som bl.a. ramte Mærsk økonomisk i sommeren 2017. I alle tilfældene er implikationen øget usikkerhed, fordi angrebene viser sårbarheden af de systemer, som får samfundet til at hænge sammen - og som vi alle sammen er afhængige af.

Det er imidlertid ikke kun ved deciderede angreb og spionage, at cybertruslen skaber problemer for de vestlige demokratier. Faktisk udgør de på andre måder en mere subtil udfordring. I den nylige rapport Rethinking Cybersecurity fra Center for Strategic \& International Studies pointeres det, at USA og andre vestlige stater har overvurderet risikoen for, at angreb fører til en 'cyberkatastrofe', men har undervurderet betydningen af cybertruslen $i$ forbindelse med påvirkningskampagner i de åbne samfund.

Den digitale udvikling har ganske enkelt transformeret mulighederne for informationskrigsførelse.

\section{Påvirkningskampagner}

Den aktuelle politiske konflikt imellem Rusland og Vesten er i høj grad en kamp om at styre informationsstrømme. Det handler både om at kontrollere, hvem der kan modtage og sprede information, og om at kontrollere indholdet af den information og misinformation, som påvirker den offentlige debat og beslutningsprocesserne i de enkelte lande. 
I denne sammenhæng giver de digitale værktøjer Rusland nye muligheder for at forfølge velkendte strategier og taktikker på en mere effektiv måde. Under den kolde krig gennemførte Sovjetunionen årtier lange påvirknings- og misinformationskampagner i vestlige lande og tredjeverdenslande. I den digitale tidsalder er mulighederne for at føre denne slags kampagner vokset. Det sker ikke mindst på sociale medier, hvor alle har adgang til at interagere og påvirke informationsstrømmene på tværs af grænser. I de åbne samfund giver det eksterne aktører et nyt og omfattende spillerum.

Der er efterhånden mange eksempler på, at Rusland formår at udnytte det nye spillerum. Eksempelvis gennemgår en gruppe forskere i en særudgave af The Warsaw Institute Review fra 2017 en række tilfælde, hvor Rusland har spredt misinformation i de central- og østeuropæiske lande. Dertil kommer de veldokumenterede russiske forsøg på at påvirke demokratiske valg i bl.a. USA, Frankrig, Storbritannien og Holland. Det er derfor ikke overraskende, at FE vurderer, at 'det er sandsynligt, at russiske påvirkningskampagner vil udgøre en stigende trussel også mod Danmark.

Et meget omdiskuteret konkret eksempel er den russiske misinformationskampagne i forbindelse med Lisa-sagen i Tyskland i januar 2016. Den 13-årige russisk-tyske pige Lisa blev i russiske medier rapporteret kidnappet og voldtaget af indvandrere. Historien viste sig at være et falsum. Alligevel blev den spredt på sociale medier, og der blev arrangeret demonstrationer, som fangede de nationale tyske mediers interesse. Affæren endte i diplomatiske spændinger mellem Tyskland og Rusland efter kritiske udtalelser fra den russiske udenrigsminister om politisk korrekthed i det tyske retssystem. Russerne anvendte dermed internettets muligheder til at puste til interne tyske uenigheder om indvandring og håndteringen af migrationskrisen.

En tilsvarende logik drev Ruslands indblanding i det amerikanske præsidentvalg i 2016, hvor russiske hackere skaffede sig adgang til daværende præsidentkandidat Hillary Clintons emails. Dokumenterne blev lækket og brugt som brænde på bålet i den polariserede amerikanske debat om Clintons personlige karakter. Samtidig gennemførte russerne både i statskontrollerede medier som Russia Today og på sociale medier en omfattende fake news-kampagne for at præge den offentlige debat i USA.

Eksemplet viser, at nye digitale værktøjer muliggør kombinationer af deciderede cyberangreb og bredere påvirkningskampagner. Tilsammen kan de skabe væsentlige effekter på interne politiske dynamikker i demokratiske samfund. Det er et stort og akut problem for Danmark, Europa og Vesten. FE's risikovurdering viser, at den danske stat er nået til samme erkendelse. Spørgsmålet er, hvad man kan gøre ved det.

\section{En fornyet sikkerhedspolitisk debat}

Der er ikke noget simpelt svar på, hvordan de åbne samfund kan håndtere de sikkerhedspolitiske udfordringer i den digitale tidsalder. Men det gør blot sikkerhedspolitisk og demokratisk debat om emnet så meget desto vigtigere.

I sikkerhedspolitisk øjemed er det væsentligt at gøre sig overvejelser om de forskellige veje, man kan gå i håndteringen af cybertruslen. Man kan anlægge en defensiv tilgang for at forbedre sin egen cybersikkerhed eller en mere offensiv tilgang med fokus på at svække, afskræk- 
Debatten om cybertruslen handler imidlertid om mere end sikkerhedspolitik. Den handler også om større demokratiske udfordringer. Digitaliseringen af samfundet og de trusler, som den udvikling bærer med sig, sætter nye spørgsmål om relationen mellem stat, borger og civilsamfund i spil.

ke eller direkte eliminere modpartens cyberkapaciteter.

Endnu mere offensivt kan man vælge at besvare et cyberangreb med konventionelle militære midler. Denne mulighed afvises hverken af USA eller NATO. Man kan også satse på, at den teknologiske udvikling - og måske private aktører - vil skabe nye måder at afværge cybertruslen. Alternativt kan man arbejde på stærkere international regulering. Hvis man vælger reguleringsvejen, skal man desuden overveje, om det betyder international regulering i retning af en global cybertraktat - med bl.a. Rusland - eller tiltag mod fake news og misbrug af sociale medier i de vestlige lande, i tråd med dem som både EU og den franske præsident Emmanuel Macron har lanceret.

Det skal ikke forstås sådan, at de forskellige veje er gensidigt udelukkende. Ikke desto mindre entrerer man med cybertruslen på nogle måder ukendt farvand. Dette indebærer en risiko for, at forskellige initiativer kan have utilsigtede konsekvenser. Måske kan de ligefrem underminere hinanden, hvis de iværksættes parallelt. Dertil kommer altid begrænsede ressourcer. Der kræves med andre ord både overvejelser om risici, konsekvenser og prioriteringer, når Danmark alene og med allierede skal vælge, hvordan man søger at håndtere cybertruslen.

\section{Handler også om demokrati}

Debatten om cybertruslen handler imidlertid om mere end sikkerhedspolitik. Den handler også om større demokrati- ske udfordringer. Digitaliseringen af samfundet og de trusler, som den udvikling bærer med sig, sætter nye spørgsmål om relationen mellem stat, borger og civilsamfund i spil.

For det første har cyberredskaber nogle egenskaber, der modvirker demokratisk debat om dem. I modsætning til fx atomvåben, der skal vises for at have en effekt, virker cybervåben kun, indtil de er blevet vist frem. Deres effekt afhænger af, at de holdes hemmelige. Derudover er meget teknisk viden på cyberområdet i private hænder - og derfor også forretningshemmeligheder. Begge dele besværliggør en offentlig debat om emnet.

Disse besværligheder forstærkes af, at vi i Danmark har valgt at lægge store dele af ansvaret for statens ageren på cyberområdet hos netop $\mathrm{FE}$ - den mest hemmelige del af staten, som i forvejen fungerer uden for normale demokratiske forvaltningsnormer og principper om åbenhed og gennemsigtighed.

For det andet betyder den digitale udvikling, at også Danmark på ny må beskæftige sig med bredere spørgsmål om forholdet mellem staten og samfundet i tilvejebringelsen af sikkerhed.

I øjeblikket foregår der i flere af de nordiske lande en intens debat om 'resiliens' eller modstandsdygtighed over for nye typer af trusler, herunder cybertruslen. Det kommer fx til udtryk i rapporten om 'motståndskraft' fra december 2017, som er udarbejdet af en kommission under det svenske forsvarsministerium.

Ligeledes pointerede den norske forsvarsminister Frank Bakke-Jensen i en 
tale den 8 . januar 2018, at nordmændene 'må bygge et sterkt og motstandsdygtig samfunn', og at bl.a. 'cybervåpen gjør at flere må samhandle på annen måte enn tidligere'. De svære dele af de diskussioner handler i høj grad om, hvilke forpligtigelser henholdsvis statslige myndigheder, civilsamfund, private virksomheder og borgere har i denne sammenhæng.

Udviklingen indebærer altså også nye spørgsmål om statens ansvar over for sine borgere og over for private aktører i videre forstand. Hvornår er et cyberangreb et personligt, kommercielt eller statsligt anliggende?

Hvis Mærsks anslåede tab på ca. 1,6 mia. kroner ved cyberangrebet i sommeren 2017 havde været resultatet af et bombeangreb på Fredericia havn eller en boreplatform i Nordsøen, havde vi vel alle forventet et andet svar fra den danske stat. Hvordan vil situationen være ved politisk motiveret identitetstyveri over for statsligt ansatte, fx i Forsvarsministeriet? Hvilket ansvar har staten for at passe på den (ofte følsomme) information, den indhenter fra sine borgere?

Mere generelt må man spørge: Hvilke rettigheder og pligter har borgere og virksomheder over for staten - og omvendt når det faktisk er staten, der ad omveje er mål for cyberangrebene?

Endelig er cybertruslen et styringsmæssigt problem. Det er kompliceret, potentielt dyrt og går på tværs af ressortområder. Dyre problemer uden et klart ressort er notorisk svære at håndtere. Det viser ventetiden på den forsinkede, tværgående cyberstrategi, der blev lovet i regeringsgrundlaget fra 2016. Når strategien kommer, skal vi derfor hverken forvente, at de sikkerhedspolitiske eller demokratiske udfordringer knyttet til cyberområdet er løst.

Debatten om cybertruslen vil fortsætte - og bør i langt højere grad sættes i en bredere politisk kontekst. 


\section{Migration som trussel mod sammenhængskraft}

Af Frede Vestergaard

Sikkerheds- og stabilitetspolitik er mere end militær sikkerhed, som det rettelig fremgår af Taksøe-Jensen-rapporten og regeringens udenrigs- og sikkerhedspolitiske strategi med henvisning til den massive befolkningstilvækst i Mellemøsten og Nordafrika. Migration som sikkerhedspolitisk udfordring for EU er undervurderet, fordi fokus rettes mod flygtninge og migranters vilkår og ignorerer de langsigtede konsekvenser for sammenhængskraften i modtagerlandene.

'Migration, ustabilitet og terrorisme' er et af de fem hovedemner/trusler i regeringens udenrigs- og sikkerhedspolitiske strategi for 2017-18; den første, der nogensinde er eksplicit formuleret. Regeringen vil arbejde for at mindske migrationsog flygtningepresset samt terrortruslen mod Europa og Danmark.

Danmark skal ifølge strategien 'forebygge nye flygtninge- og migrationsstrømme ved at skabe fred, sikkerhed og bedre fremtidsudsigter for mennesker dér, hvor de hører hjemme. Det kræver en styrket nærområdeindsats for at fremme stabilitet, vækst og udvikling i Mellemøsten og Afrika samt en bedre sikring af Europas grænser, lyder det.

Målet afspejler analysen af Danmarks udenrigspolitiske udfordringer i Taksøe-Jensen-rapporten Dansk diplomati og forsvar i en brydningstid. Vejen frem for Danmarks interesser og vordier mod 2030. Den er ikke snævert fokuseret på det militære, i modsætning til den forrige store sikkerhedspolitiske analyse, Hans Henrik Bruun-rapporten De sikkerhedspolitiske vilkår for dansk forsvarspolitik fra 2003, hvor ordene migration og illegale indvandrere kun akkurat bliver nævnt i forbifarten.

Men i dag dominerer flygtninge- og migrationsspørgsmålet den danske og europæiske debat som aldrig før. Omkring 1,3 mio. søgte asyl i Europa i 2015, og andre 1,2 mio. i 2016 ifølge Eurostat, mens tallet i 2017 ser ud til at være halveret til ca. 600.000 .

Faldet skyldes, at vestbalkanruten er lukket af landene langs ruten, og at EU på grund af stærk folkelig modvilje mod den

Frede Vestergaard er journalist med tilknytning til Weekendavisen. Han er uddannet cand.polit. og skriver blandt andet om de samfundsmæssige konsekvenser af den økonomiske udvikling, ofte med særlig interesse for bl.a. energi og miljø. 


\section{Den indre sikkerhed og stabilitet for Danmark og Europa handler om andet end potentiel terror. Den er et spørgsmål om migrationens omfang og dermed de økonomiske og sociale omkostninger ved at modtage et stort antal mennesker,}

ukontrollerede indvandring i 2015 i foråret 2016 indgik aftaler med Tyrkiet om, at EU bidrager kraftigt til at finansiere Tyrkiets udgifter til flygtningelejre for syriske flygtninge, mod at Tyrkiet ikke lader syriske og andre flygtninge rejse videre til Europa. Men middelhavsruten var fortsat åben. Siden har Italien i eftersommeren 2017 truffet aftaler med Libyens magthavere om at begrænse denne kanal.

Den folkelige modvilje mod den ukontrollerede indvandring til Europa i 2015 og 2016 har givet vind i sejlene til såkaldt populistiske partier, der tager afstand fra 'masseindvandringen'. Det er partier, som ofte forbinder EU med manglende løsninger på problemet. Det er der ifølge en holdningsundersøgelse fra amerikanske Pew Research Center fra september 2016, som omfatter 10 lande i Europa (dog ikke Danmark) stor klangbund for at gøre.

På den måde truer migrationen EU-samarbejdet med delvis opløsning. Indvandring spillede en afgørende rolle i juni 2016, da et flertal i UK - hvor Tony Blair i 1997 havde lempet reglerne for indvandring fra de tidligere kolonier - stemte ja til at forlade EU. I de fleste af de 'nye' EU-medlemslande i øst er der stor folkelig modvilje mod at blive dikteret at modtage flygtninge fra Mellemøsten som led i en EU-fordelingsordning, men det samme er tilfældet $i$ andre lande. I øvrigt ville sådanne tvangsplacerede flygtninge i de fattigste EU-lande formentlig efterfølgende søge mod mere velstående EU-lande som bl.a. Tyskland, hvorfra de ville have lettere ved at sende penge hjem til familien.

Der har i medierne været en tilbøje- lighed til at slå sig til tåls med, at de såkaldte populistiske partier ikke fik så stor fremgang - som medierne selv havde stillet i udsigt - ved valgene i 2017 i Frankrig, Tyskland, Holland, Østrig og Norge, men det skyldes bl.a., at de etablerede partier havde skærpet holdningen til indvandring. Og rent faktisk var tilslutningen ikke desto mindre stor til de indvandringskritiske partier.

I Italien, hvor der skal være valg i år, spiller spørgsmålet om kravene til italiensk statsborgerskab for migranter en stor rolle i valgkampen. I Sverige, hvor der skal være valg til september, har Socialdemokraterne og de fleste borgerlige partier reelt overtaget de indvandringskritiske Sverigedemokraters dagsorden, samtidig med at de holder sig for næsen, når de nærmer sig en sverigedemokrat.

\section{Økonomisk og social trussel}

Migrationen er ikke en militær trussel. Den kan potentielt lede til et antal religiøst inspirerede terrorhandlinger. Men selv de cirka 3.000 omkomne fra 9/11 er kun en lille brøkdel af eksempelvis antallet af trafikdræbte i USA hvert år.

Den indre sikkerhed og stabilitet for Danmark og Europa handler om andet end potentiel terror. Den er et spørgsmål om migrationens omfang og dermed de økonomiske og sociale omkostninger ved at modtage et stort antal mennesker, der ikke har forudsætninger for at klare sig på et arbejdsmarked, der i høj grad forudsætter et veluddannet personale. Og hvor lavt uddannet personale løser serviceopgaver såsom fx rengøring. De manuel- 


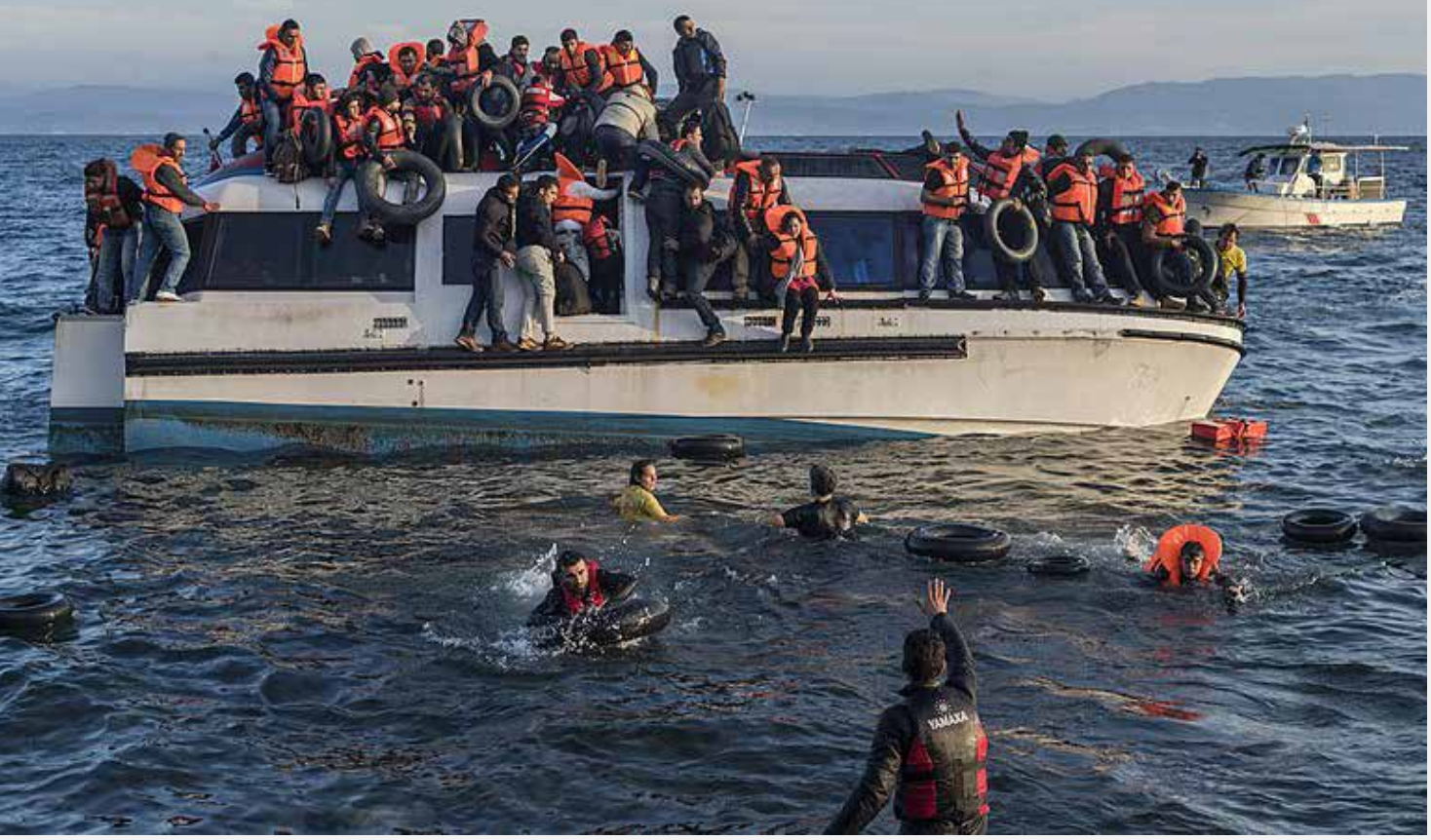

FOTO: Ggia via wikimedia commons

Syriske og irakiske flygtninge ankommer fra Tyrkiet til Lesbos, Grækenland, oktober 2015

le arbejdspladser i industrien er i vidt omfang udflyttet til lande med lavere løn eller er automatiseret og kræver højt kvalificeret personale.

At antallet også på kort sigt betyder noget, leverede Sverige et utvetydigt eksempel på i efteråret 2015. Mens den tyske forbundskansler Angela Merkel på sin pressekonference den 31 . august, som kommentar til det store antal asylsøgende, der søgte mod Tyskland, udtalte: "Vi har klaret så meget - vi klarer det" (Wir haben so vieles geschaftt - Wir schaffen dass), modtog Sverige så relativt mange flere end Tyskland, at statsminister Stefan Löfven den 24. november måtte meddele - med en grædende vicestatsminister Åsa Rom- son fra Miljøpartiet ved sin side - at Sverige strammede kraftigt op og gennemførte forskellige indgreb, der skulle få flygtninge til at søge asyl i andre EU-lande.

I Regeringskansliets pressemeddelelse fra den 24. november 2015 hed det: "Efter sommeren er antallet af flygtninge, som søger til Sverige, øget kraftigt, og bare i de sidste to måneder har 80.000 personer søgt asyl i Sverige. Af dem er der så mange børn og unge, at det modsvarer 100 nye skoleklasser hver uge. Myndigheder og kommuner har nu svært ved at klare opgaverne (...) Myndigheden for samfundsbeskyttelse og beredskab slår alarm $\mathrm{om}$, at vigtige samfundsfunktioner ikke kan klare opgaverne. Sverige kan ikke 
længere garantere tag over hovedet for dem, som søger til vort land, og den sidste uge har mennesker været tvunget til at sove udendørs. Derfor foreslår regeringen nu en række tiltag for at skabe et pusterum for svensk flygtningemodtagelse. Det kræver, at antallet af personer, som søger asyl og bevilges opholdstilladelse i Sverige, mindskes kraftigt. Regeringen vil derfor $i$ en periode tilpasse asylreglerne til EU's minimumsniveau for, at flere skal vælge at søge asyl i andre EU-lande".

Sverige indførte derfor ID-kontrol på færgen mellem Helsingør og Helsingborg samt på tog og busttrafikken over Øresundsbroen, men ikke på færgeruterne mellem Tyskland og Sverige, hvilket medførte, at også Danmark indførte grænsekontrol ved grænsen til Tyskland. Desuden ville asylsøgende fremover kun få midlertidig opholdstilladelse på tre år, der dog kunne forlænges, hvis flygtningen kunne opvise en skattepligtig indkomst på et niveau, som man kan leve af. Forud for kursskiftet var flygtninge fra Syrien siden 2013 på forhånd garanteret permanent opholdstilladelse, hvis de mødte op i Sverige. Indgrebet gjaldt også personer, der var ankommet før den 24 . november, men ikke havde fået deres sag behandlet.

Et anden vigtig ændring var, at en flygtning kun kunne få sin kernefamilie familiesammenført - ikke den udvidede familie - og at begge ægtefæller skulle være mindst 21 år. Der kom også krav om, at personen, der søger om familiesammenføring, skal kunne forsørge familiemedlemmer, der kommer til Sverige. Endelig blev det besluttet, at uledsagede børn un- der 18, som hidtil havde ret til at få familien til Sverige, hvis de fik asyl, fremover skulle aldersbestemmes medicinsk, hvis der var tvivl om alderen (i 2015 kom ca. 35.000 overvejende af hankøn).

Efterfølgende besluttede de regeringsbærende Socialdemokrater på deres kongres i oktober 2017, at Sverige bør bevare grænsekontrollen for øget sikkerhed, og fordi "sikkerhedssituationen i Europa er sådan, at vi behøver at have kontrol med vore grænser, ikke mindst på baggrund af terrorangrebet, som skete i Sverige den 7 . april", som det hed på partiets hjemmeside.

At så mange syriske flygtninge søgte til Sverige skyldtes i første række, at Sverige fra 2013 på forhånd havde garanteret permanent opholdstilladelse til asylsøgere, der nåede frem til Sverige. Men undersøgelserne viser også, at en hel del kom, fordi de i forvejen havde mere eller mindre fjern familie i Sverige som følge af Sveriges tre årtiers liberale praksis for tildeling af asyl til personer fra bl.a. Mellemøsten kombineret med generøse regler for efterfølgende familiesammenføring.

\section{Familiesammenføringer}

Også under fredelige omstændigheder spiller familiesammenføringsreglerne en stor rolle for visse grupper.

Ægteskab på tværs af grænser mellem personer fra højindkomstlande fører ikke til yderligere familiesammenføring via deres børn - $\mathrm{i}$ hvert fald ikke kun én vej - og parret slår sig ikke systematisk ned i det ene land frem for det andet.

Derimod har der hidtil været en meget

\footnotetext{
Ægteskab på tværs af grænser mellem personer fra højindkomstlande fører ikke til yderligere familiesammenføring via deres børn - i hvert fald ikke kun én vej - og parret slår sig ikke systematisk ned i det ene land frem for det andet.
} 
stærk tendens til, indvandrere/flygtninge, der allerede er kommet til et højindkomstland fra lavindkomstlande, hvor det er kulturel praksis, at familierne bestemmer eller har meget stor indflydelse på, hvem børnene skal gifte sig med, bruger et giftemodent barn som visum for en ægtefælle fra den udvidede familie i lavindkomstlandet til højindkomstlandet.

For Danmarks vedkommende er væksten $\mathrm{i}$ indvandrerbefolkningen med tyrkisk baggrund et klart eksempel på betydningen af familiesammenføringsregler. Da der blev lukket for arbejdskraftindvandring til Danmark fra ikke-EU-lande i 1973, var der knap 6.000 tyrkiske statsborgere i Danmark. De er siden ved familiesammenføringer, fødsler og andengenerationens henteægteskaber og børnebørn vokset til mindst 62.600 pr. 1. januar 2017 ifølge Danmarks Statistiks opgørelser. Til sammenligning er Tyrkiets folketal kun fordoblet i samme periode.

Denne praksis blev fra begyndelsen af nullerne $i$ et vist omfang begrænset som følge af bl.a. 24-årsreglen og tilknytningskravet, som senere er udhulet eller blokeret af domme fra Den Europæiske Menneskerettighedsdomstol. Betydningen af, at nye familier dannes ved henteægteskaber, er, at integrationen starter forfra, fordi det nye ægtepar typisk vil tale tyrkisk, arabisk, urdu osv. indbyrdes. Altså taler de ikke dansk i hjemmet eller ser dansk tv, men $\mathrm{fx}$ arabisk. Dette i modsætning til fx et dansk-brasiliansk ægtepar.

\section{Andengenerationsbørn}

Anden generation begynder derfor i skolen med svage danskkundskaber. Indvandrerbørn klarer sig gennemsnitligt dårligt i skolen, fremgår det af resultaterne fra folkeskolens afgangsprøver. Det er ikke et særligt dansk fænomen. Det forekom- mer også i andre lande i Europa. Det viser de såkaldte PISA-undersøgelser fra OECD. Diverse undersøgelser viser i øvrigt, at det hæmmer indlæringen også for majoritetseleverne, hvis antallet af indvandrer- eller andengenerationsbørn udgør et betydeligt mindretal i en skoleklasse. Det er en af migrationens sociale trusler: Indvandring skaber ulighed, og uligheden begynder i skolen. Stor ulighed er destabiliserende, i særlig grad når der opstår en synlig underklasse.

Dårlige resultater i grundskolen bremser muligheden for videre uddannelse, $\mathrm{i}$ særdeleshed for indvandrerdrengene, der klarer sig dårligst. Mange falder fra på uddannelser efter folkeskolen og bliver afhængige af diverse offentlige ydelser, fordi de mangler jobkvalifikationer. Og de unge kvinder bliver i vidt omfang hjemmegående efter at have fået børn, for sådan er det kulturelle mønster i familiens oprindelsesland.

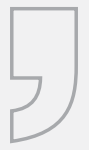

\section{Det er en af migrationens sociale trusler: Indvandring skaber ulighed, og uligheden begynder $\mathrm{i}$ skolen.}

Det er i øvrigt interessant, at i OECD's PISA-undersøgelse fra 2006 klarer immigrantelever sig lise så godt som majoritetsbefolkningen i tre traditionelle immigrantlande: Australien, Canada og New Zealand. Det fremgår ikke, hvad årsagen kan være, fx om det er et andet mix af indvandrere, eller om forklaringen er, at disse lande i mindre grad har karakter af velfærdsstater end mange europæiske lande. Hvis det sidste er tilfældet, er majoritetsbefolkningen i europæiske lande så villig til at acceptere, at velfærdssystemet (overførselsindkomsterne) af ikke-diskriminatoriske grunde forringes for alle for at få integrationen til at fungere? 
Lave beskæftigelsesfrekvenser for både mænd og i særdeleshed kvinder betyder, at ikke-vestlige indvandrere som gruppe betragtet gennemsnitligt modtager væsentligt større beløb fra eksempel dagpenge, kontanthjælp og førtidspension, end de selv betaler i skat. De ikke-vestlige efterkommere klarer sig bedre end forældregenerationen, men har som forældrene en lavere beskæftigelsesfrekvens end majoritetsbefolkningen.

\section{Økonomisk belastning}

Tilsammen begrænser det majoritetsbefolkningens muligheder for offentlig velfærd, som det har været tilfældet i en årrække. En undersøgelse fra Finansministeriet fra april 2017 angiver et tal på 16 mia. kr. for ikke-vestlige indvandrere og 17 mia. kr. for ikke-vestlige efterkommere, i alt 33 mia. kr. i nettobelastning af de offentlige finanser, svarende til halvanden pct. af BNP. Det samme ses i andre velfærdsstater i Vesteuropa. I Sverige var det godt to pct. af BNP før den seneste indvandringsbølge.

I lande som Storbritannien og de overs $\emptyset$ iske angelsaksiske lande er det anderledes. Der er den offentlige hjælp til personer i den arbejdsdygtige alder uden for arbejdsmarkedet begrænset i størrelse og varighed, og forskellen i beskæftigelsesfrekvens mellem indvandrere og majoritetsbefolkning er meget lille. Det er et forhold, der jævnligt afspejler sig i angelsaksiske analytikeres beskrivelse af den økonomiske betydning af indvandring, som de derfor anser for positiv.

Men i de europæiske velfærdsstater med relativt generøse overførselsindkomster og lønninger, som forudsætter en kvalificerende uddannelse, er det anderledes. Integrationen fungerer dårligt. Det lægger et pres på sammenhængskraften, at det er synligt, hvem der modtager, og hvem der betaler.
Desuden bidrager det til at øge uligheden i samfundet, at en overgennemsnitlig andel af de - med et canadisk begreb - synlige minoriteter i så udstrækning lever af offentlige ydelser eller af lavtlønnet servicearbejde som $\mathrm{fx}$ rengøring.

Sammenhængskraft er svært at definere; det handler bl.a. om kulturel identitet og kulturdissonans, social tillid og negative følelser over for ukontrolleret indvandring af flygtninge og økonomiske migranter hos store dele af den residerende befolkning, fordi de må afgive noget af det, som de og deres forfædre har skabt, eftersom der ikke må diskrimineres. Alternativet er at basere sociale ydelser og pensioner samt adgang til sundhedsydelser m.m. på optjenings- og forsikringsprincipper som i USA.

Det vil gøre det meget mindre attraktivt at søge til Danmark og Europa, men det ville også ramme 'vore egne' og dermed splitte sammenhængskraften. Det er ét af dilemmaerne.

\section{Momentum for fortsat migrationsvækst}

Familiesammenføringen og boligpolitikken - hvor indvandrere og flygtninge koncentrerer sig i store boligkomplekser, som oprindelig blev bygget til majoritetssamfundets lavindkomstfamilier - bidrager til at migrationen fremmer såkaldte parallelsamfund. Noget der forekommer i en række lande i Vesteuropa.

Familiesammenføringsreglerne skaber som nævnt i sig selv et momentum for fortsat vækst i indvandrerbefolkningen i Europa. Det samme gør den voldsomme befolkningsvækst i Europas sydlige og sydøstlige nærområder.

Taksøe-Jensen-rapporten nævner, at der på grund af befolkningssammensætningen med en høj andel unge er udsigt til en befolkningsvækst på 25 pct. i Mel- 
lemøsten og Nordafrika, mens der i Afrika i øvrigt er udsigt til en vækst på 40 pct. Med en sådan vækst er der ingen udsigt til, at migrationskrisen stopper af sig selv. Næppe heller ved at Danmark - sammen med andre lande - ved hjælp af udviklingsbistand m.m. søger at "forebygge nye flygtninge- og migrationsstrømme ved at skabe fred, sikkerhed og bedre fremtidsudsigter for mennesker dér, hvor de hører hjemme", som det hedder i regeringens udenrigs- og sikkerhedspolitiske strategi. Økonomiske migranter vil fortsat tro, at det bedste, de kan gøre for hurtigt at blive 'rige', er at komme til Europa og arbejde.

Og der vil utvivlsomt hen ad vejen også komme en række konflikter, der giver anledning til nye, store flygtningestrømme. Skal de stoppes, før de når ind over Europas grænser, vil der være brug for aftaler med Tyrkiet, Ægypten, Libyen og Maghreb-landene om at forhindre dem $\mathrm{i}$ at sætte både i vandet.

Et særligt problem er den illegale indvandring, som ofte opstår, når en asylsøger får afslag og alligevel forbliver i landet, eller når en person fra et ikke EU-land forbliver efter et visums eller opholdstilladelses gyldighedsperiode for at arbejde. Ifølge sagens natur er tallet svært at opgøre. Rockwoolfondens forskningsenhed har for Danmark benyttet sig af, hvor mange personer politiet er kommet i kontakt med ved diverse kontrolforanstaltninger på arbejdspladser, og når med forholdsvis stor usikkerhed frem til, at det i 2016 var 22.000 personer (med 95 pct. sandsynlighed mellem 19.000 og 25.000) mod 18.000 i 2015 og 12.000 i 2010. Den svenske, grønne og liberale hjemmeside migrationsinfo.se nævner, at man regner med mellem to og 8,8 millioner illegale indvandrere for hele EU.

En opstramning af den europæiske ind- vandringspolitik er dog ikke så ligetil.

Dels er der konventionerne og dertil Den Europæiske Menneskerettighedsdomstols dynamiske, udvidende fortolkning af Den Europæiske Menneskerettighedskonvention, som regeringen har erklæret at ville se kritisk på, mens Danmark i første halvår 2018 har formandskabet for Europarådet.

Dels er der hensynet til dem, der allerede er her. I Danmark er antallet af ikkevestlige indvandrere og deres efterkommere lige så stille vokset fra godt $50.000 \mathrm{i}$ 1980 til knap en halv million i 2016. Som med alle demografiske bevægelser er ændringen lille fra det ene år til det andet, men den akkumulerer.

Og dels er der i alle lande et stort mindretal, der afviser indvandringen som et problem og anser etnicitet og social og national/kulturel affinitet - som spiller en stor rolle for flertallet - for ligegyldige sociale konstruktioner af forestillede fællesskaber.

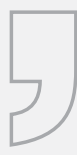

\section{Økonomiske migranter vil fortsat tro, at det bedste, de kan gøre for hurtigt at blive 'rige', er at komme til Europa og arbejde.}

Desuden er mediernes vinkling over for offentligheden af flygtninge- og indvandrerproblematikken som regel motiveret af et synd-for-dem-syndrom. Det samme gælder for migrationsforskeres og ngo' ers tilgang til migrationen, som snarere er, hvordan flere flygtninge og migranter kan hjælpes til Europa, end at tage bestik af, at et flertal - sommetider et stort flertal - af befolkningen i modtagerlandene er imod storstilet indvandring fra ikke-vestlige lande på grund af de langsigtede økonomiske, sociale og kulturelle konsekvenser og konfrontationer; fordi de ser migra- 
tionen $\mathrm{i}$ både de enkelte lande og mellem EU-landene indbyrdes som en trussel mod sammenhængskraften.

\section{Behov for indvandring til Europa?}

Men er der ikke behov for (flygtninge) indvandring til Europa på grund af de lave fødselstal i mange lande og befolkningens aldring. Umiddelbart kan det se sådan ud, men systematisk indvandring med det formål at skaffe arbejdskraft er kortsigtet generationsegoisme. Den er en umiddelbar hjælp, men udskyder bare problemet med mangel på arbejdskraft. Byrden ved befolkningens aldring bliver blot endnu større i fremtiden. Flygtningeindvandring må begrundes humanitært og ikke med mangel på arbejdskraft.

Denne problemstilling blev i begyndelsen af nullerne påvist af FN's befolkningsdivision i New York i en analyse med titlen Replacement Migration: Is it a solution to declining and aging populations?

FN's demografer satte sig for at analysere, hvad det ville betyde, hvis det lave fødselstal i mange europæiske lande - og visse andre lande i verden - med en fertilitetsrate under to, blev erstattet af indvandrere. De beregnede, hvad det vil betyde, hvis man for de daværende 15 EU-lande med 375,7 millioner indbyggere i 2000:

- Vil opretholde et uændret folketal fra 1995-2050, eller

- Vil opretholde en uændret arbejdsstyrke defineret som de 15-64-årige, eller

- Vil opretholde en uændret forsørgerkvote, defineret som forholdet mellem de 15-64-årige og gruppen af personer på 65 år og derover.
En uændret befolkning vil med de givne antagelser kræve en indvandring til de daværende 15 EU-lande på 47,5 mio. frem mod 2050. En uændret arbejdsstyrke vil kræve en indvandring på 79,4 mio. frem mod 2050, mens en uændret forsørgerkvote vil kræve en indvandring på 674 mio. frem mod 2050

Tallene kommer oven i en forudsat indvandring til EU-15 i FN's grundscenarie på 300.000 om året eller 16,1 millioner frem til 2050.

Beregningerne viste altså, at der er tale om et pyramidespil, hvis manglen på arbejdskraft skal løses ved indvandring. I løbet af få årtier vil der ske en eksplosiv vækst i det samlede folketal - og værtsbefolkningen vil med en antagelse om uændret forsørgerkvote blive en minoritet.

Ved FN-beregningerne er antaget, at en person, der glider ud af arbejdsstyrken på grund af alder, uden videre problemer kan erstattes af en indvandrer, samt at indvandrerne straks overtager værtsbefolkningens lave fertilitet.

Når værtsbefolkningen kan komme i klart mindretal i løbet af ganske få årtier, er forklaringen, at indvandrerne også bliver gamle og skal erstattes af nye indvandrere. Systematisk indvandring af arbejdskraft er en kortsigtet løsning, som øger forsørgerbyrden på længere sigt - med mindre altså, at indvandrerne hentes til Europa for at arbejde i nogle år og derefter returnerer til deres hjemland, som det bl.a. kendes fra Singapore for 'low-skilled workers' og fra de arabiske Golf-lande.

Løsningen på befolkningens aldring er i første række, at værtsbefolkningen ar-

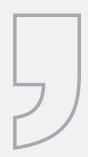

\footnotetext{
Systematisk indvandring af arbejdskraft er en kortsigtet løsning, som øger forsørgerbyrden på længere sigt - med mindre altså, at indvandrerne hentes til Europa for at arbejde i nogle år og derefter returnerer til deres hjemland, som det bl.a. kendes fra Singapore.
} 
bejder - og betaler skat - i flere år end de nærmest foregående generationer. I mange lande i Europa er pensionsalderen stadig temmelig lav - og tiden på pension er mærkbart længere end for tidligere generationer på grund af længere middellevetid. Dog har man i en række lande under store protester fra faglige organisationer fået hævet pensionsalderen en smule i de senere år. I nogle europæiske lande er kvindernes erhvervsfrekvens desuden noget lavere end i bl.a. de skandinaviske lande, så her er der også arbejdskraftreserver at trække på.

\section{Konklusion}

Migration er blevet kaldt globaliseringens menneskelige ansigt, men den er ikke en selvfølgelig konsekvens af globalisering. Tværtimod bygger væksten i international handel og specialisering på, at der er forskel på produktionsomkostningerne i forskellige lande, og at folk i lavindkomstlande ikke kickstarter vejen til velstand ved at flytte til et højindkomstland.

Få problemer i Europa er i dag så kontroversielle som irregulær migration, der af et flertal af vælgerne opfattes som ukontrolleret, når tallet bliver stort, og antallet af synlige minoriteter akkumulerer, jævnfør en vækst i eksempelvis Danmark fra godt 50.000 til knap 500.000 på 35 år. Det skyldes til dels, at migrationen berø- rer så mange andre spørgsmål, økonomi, demografi, politik, national identitet, kultur og endog religion.

Vi befinder os i et dilemma. Vi vil undgå ulemperne og truslerne ved ukontrolleret indvandring af flygtninge og økonomiske migranter, og vi har hidtil - af humanitære grunde - villet undgå midlerne til at dæmme op for ukontrolleret indvandring med effektiv grænsekontrol og hjemsendelse, idet vi fortsat klynger os til et selvbedrag om at kunne integrere alle indvandrere, som kommer.

Men som nævnt i Taksøe-Jensen-rapporten er der udsigt til en voldsom og uafvendelig befolkningsvækst i Mellemøsten og Afrika allerede i de kommende 15 år. Det er fattige lande med et højt konfliktniveau og med potentielle flygtninge som konsekvens. Forskellige undersøgelser viser, at en meget stor andel unge i disse lande drømmer om at komme til Europa. At komme gennem 'Himlens dør' med et udtryk af den amerikansk-cubanske immigrationsøkonom George Borjas.

Derfor er migration en sikkerhedspolitisk udfordring for Danmark og EU, hvilket såvel Taksøe-Jensen-rapporten som regeringens udenrigs- og sikkerhedspolitiske strategi klogt retter blikket mod. 


\section{USA's udenrigspolitik under Trump - på afveje eller bare på Twitter?}

\section{Af Annegrethe Rasmussen}

De fleste vesteuropæiske analyser af præsident Trumps udenrigspolitik er præget af bekymring - og med god grund: aflysningen af USA's deltagelse i Paris-aftalen, kritikken af NATO, præsidentens forkærlighed for protektionisme, undermineringen af State Department, foragten for diplomatiske redskaber samt afstandtagen til frihandel og det liberale demokrati svækker de traditionelle bånd i den atlantiske alliance. I praksis afviger Trump imidlertid endnu ikke radikalt fra konservativ mainstream $i$ amerikansk udenrigspolitik. Det kan imidlertid komme, hvis ikke man forstår de understrømme af national populisme, der ligger bag Trumps valgsejr.

"Det meste af omverdenen ved, at Trump er ustabil og et narcissistisk fjols. Og derfor ser mange af Vestens politikere og diplomater heldigvis igennem præsidentens bizarre opførsel fx på Twitter og leder efter stabilitet i USA's opførsel i stedet. Ikke fordi de ønsker at skabe et urealistisk fantombillede af Trump, men fordi de selv har brug for et Amerika, de kan regne med - af de sædvanlige sikkerhedspolitiske og geostrategiske grunde."

Sådan lød det fra en erfaren diplomat fra et vesteuropæisk land, som jeg talte med i Washington D.C. i starten af januar. Diplomaten, der selv har erfaringer inden for både økonomiske forhandlinger, europæisk udenrigspolitik samt sikkerheds- og efterretningsarbejde med USA brugte ukarakteristisk hårde ord om den amerikanske præsident, men sprogbrugen er langt fra usædvanlig, når man taler med analytikere, der har rod i eliten fra 'inside the Beltway' - sikkerhedspolitiske aktører som politikere eller eksperter, der $i$ årtier har domineret Washingtons tænketanke, ambassader samt Kongressen, efterretningsagenturerne, State Department og Pentagon.

Længe lever generalerne i Trumps midte Her priser man sig lykkelig over det hårdnakkede rygte om, at præsidentens mange generaler (herunder især John Kelly, der er stabschef, Jim Mattis, der er forsvarsminister, den nationale sikkerhedsrådgiver H.R. McMaster samt Mike Pompeo, der er CIA-direktør) har indgået en 'mu-

Annegrethe Rasmussen er udenrigskorrespondent bosat i Washington og chefredaktør for det digitale medie Point of View International [POV], som hun er medstifter af. 
sketer-ed' om, at de aldrig er uden for hovedstaden eller præsidentens rækkevidde samtidig. At der med en kilde i Pentagons ord, "altid er en af dem, der er tæt på, og at præsidenten aldrig er alene med de nukleare koder."

Dette fordi der er en udbredt angst for, at den spontane præsident, der over for sine venner fortsat praler med, at han 'ikke har brug for' de daglige efterretningsbriefinger, skal foretage sig noget mere substantielt uoverlagt end blot uigennemtænkte tweets, og fordi der hersker en formodning om, at de selvsamme generaler i værste fald ville kunne forhindre en sikkerhedspolitisk katastrofe.

Her er det især forestillingen om et 'preemptive strike' over for Nordkorea, hvor præsidenten - primært via sin foretrukne kommunikationskanal, Twitter - har truet, hånet og latterliggjort den nordkoreanske diktator Kim Jong-Un.

Trump har i denne kontekst gjort sig selv til grin ved at fremhæve, at 'hans nukleare udløsningsknap er større' end Kims - "Will someone from his depleted and food starved regime please inform him that I too have a Nuclear Button, but it is a much bigger \& more powerful one than his, and my Button works!", som han tweetede.

\section{$\square$ Der er en udbredt angst for, at den spontane præsident, der over for sine venner fortsat praler med, at han 'ikke har brug for' de daglige efterretningsbriefinger, skal foretage sig noget mere sub- stantielt voverlagt end blot uigennemtænkte tweets.}

Men de erfarne sikkerheds- og udenrigspolitiske aktører er også bekymrede over, at præsidenten i så høj grad lader sin udenrigspolitik styre af rene indenrigspolitiske overvejelser - som da præsidenten godkendte Jerusalem som Israels hovedstad - og over hans uvidenhed om globale forhold, som han ofte demonstrerer. Som da han eksempelvis under samtaler med Angela Merkel foreslog kansleren at indgå en 'bilateral handelsaftale' uden at vide, at Tyskland som EU-medlem ikke kan indgå en sådan. Den tyske kansler manøvrerede udenom at ydmyge Trump ved blot at sige ja og tilføje, at en sådan aftale i givet fald ville skulle indgås 'mellem EU og USA', hvilket ikke afficerede præsidenten, der råbte til sin handelsminister, Wilbur Ross, 'Wilbur! Hørte du det? Vi laver en bilateral aftale.

Et andet velkendt eksempel var, da Trump tilsyneladende blødte op på sin modstand mod amerikansk deltagelse i Paris-aftalen om klimaet under samtaler med Emmanuel Macron, blot for at franske embedsmænd senere via samtaler med embedsmænd i Det Hvide Hus fandt ud af, at Trump udelukkende havde ment 'amerikansk genforhandling', hvilket ikke er muligt.

\section{Trumps lange synderegister}

Trumps 'synderegister', hvis man ser på, hvor USA's udenrigspolitik har ligget i årtier, er langt:

Under valgkampen skabte han, som alle læsere af Udenrigs vil være klar over, betydelig usikkerhed om NATO-samarbejdet, som han kaldte for 'obsolete' under sin valgkamp, og om end han efterfølgende kom med udglattende kommentarer, og om end såvel vicepræsident Mike Pence som forsvarsminister Mattis har forsikret de vesteuropæiske allierede om, at alt er cirka, som det altid har været, hersker der ingen tvivl om, at den mere merkantilistiske noget-for-noget retorik, som 
Trump står for i alle relationer under slagordet 'America First', også har ændret stemningen i NATO, hvor mange medlemmer har tilkendegivet, at de hæver bidraget, ligesom flere lande også øger egne forsvarsudgifter.

Det gælder også for Danmark, hvor regeringen i oktober 2017 foreslog en stigning i forsvarsudgifterne med en femtedel i løbet af de næste seks år - alt i alt foreslår regeringen at bruge 2,8 milliarder kroner ekstra på forsvaret over den kommende forligsperiode, der skal gælde frem til 2023. Det betyder, at de danske forsvarsudgifter bliver løftet fra 1,14 pct. af BNP i 2016 til 1,3 pct. af BNP fremover.

Trumps velkendte skepsis over for frihandelsaftaler førte til at han straks efter sin tiltrædelse aflyste frihandelsaftalen TPP - the Trans-Pacific Partnership - der omfattede USA, Japan, Malaysia, Vietnam, Singapore, Brunei, Australien, New Zealand, Canada, Mexico, Chile og Peru og som tilsammen står for ca. 40 pct. af verdenshandlen.

Endvidere har han bebudet, at han er mest stemt for at aflyse USA's deltagelse $i$ atomaftalen med Iran - det er ikke sket endnu, men til gengæld er sanktionerne blevet strammet. Hans egen efterretningstjeneste samt forsvarsminister har talt imod en aflysning.

Endelig har han som bekendt også trukket USA ud af den internationale Paris-aftale om kampen mod klimaforandringerne, optrappet retorikken voldsomt mod Nordkorea samt udsultet det amerikanske udenrigsministerium, State Department, hvor moralen er historisk lav, og flere ambassadørposter og politiske direktør-stillinger er forblevet ubesatte selv et år efter indsættelsen.

Den igangværende 'borgerkrig' mod den interne efterretningstjeneste, Forbundspolitiet, FBI - som især har at gøre med Trumps aggressive (forsvars)kamp over for den igangværende undersøgelse af Ruslands gerninger under valgkampen i 2016 ledet af den tidligere FBI-chef, Robert Mueller - smitter også negativt af på stemningen i de eksterne efterretningstjenester, CIA og NSA. Det konkrete efterretningssamarbejde er endnu ikke ødelagt, fortæller kilder i flere europæiske efterretningstjenester mig, men der 'tæres på hovedstolen', som det udtrykkes.

\section{Menneskerettigheder og demokrati}

Der er også nervøsitet i de fleste vesteuropæiske hovedstæder over for Trumps åbenlyse ligegyldighed over for menneskerettigheder og omvendte tilsyneladende forkærlighed for 'strongmen' og autokrater/diktatorer især Ruslands Vladimir Putin og kinesiske Xi Jinping, men også for mænd som de saudiarabiske prinser samt Filippinernes leder Rodrigo Duterte.

Da Trump i april 2017 havde sin første telefonsamtale med massemorderen Duterte - der havde et iskoldt forhold til præsident Obama, som Duterte havde kaldt for 'arrogant, black og son of a whore' - sagde den nyvalgte amerikanske præsident anerkendende ifølge det officielle transcript fra det filippinske udenrigsministerium, der blev lækket til magasinet,

Der hersker ingen tvivl om, at den mere merkantilistiske noget-for-noget retorik, som Trump stär for i alle relationer under slagordet 'America First', også har ændret stemningen i NATO, hvor mange medlemmer har tilkendegivet, at de hæver bidraget, ligesom flere lande også øger egne forsvarsudgifter. 
The Intercept: "Many countries have the problem [with drugs], we have a problem, but what a great job you are doing, and I just wanted to call and tell you that."

Den opførsel viser, som det respekterede britiske magasin the Economist, skrev i november 2017, at Trumps største skadevirkning i udenrigspolitikken i dag muligvis ligger inden for den 'bløde udenrigspolitik' - soft power. Som magasinet skriver i to rammende citater:

\section{Der er trusler fra valgkamp- en som ikke er ført ud $i$ livet: Præsidenten har ikke startet en handelskrig med Kina, ligesom han heller ikke har aflyst frihandelsaftalen NAFTA.}

"This is new. Previous American presidents supported despots for reasons of cold-war realpolitik. ("He's a bastard, but he's our bastard," as Harry Truman is reputed to have said of an anti-communist tyrant in Nicaragua.) Mr Trump's attitude seems more like: "He's a bastard. Great!" This repels America's liberal allies, in Europe, East Asia and beyond. It emboldens autocrats to behave worse."

Og efterfølgende i en konklusion fra samme artikel:

"For all its flaws, America has long been the greatest force for good in the world, upholding the liberal order and offering an example of how democracy works. All that is imperilled by a president who believes that strong nations look out only for themselves. By putting 'America First', he makes it weaker, and the world worse off.'

\section{Godt og skidt}

Når alt dette er sagt, står det også klart, at der er trusler fra valgkampen som ikke er ført ud i livet: Præsidenten har ikke star- tet en handelskrig med Kina, ligesom han heller ikke har aflyst frihandelsaftalen NAFTA, som han ellers har kaldt for 'den værste handelsaftale nogensinde, fordi den ikke gavner USA nok eller skaber for mange arbejdspladser uden for Amerika.

Også her spiller Trumps velkendte nulsums-tilgang til verden ind. Enten er man 'en taber' eller også er man 'en vinder' - og set gennem disse sorthvide briller vinder eksportørerne, mens importørerne følgelig taber.

Det er derfor også alt for tidligt at slappe af her, eftersom NAFTA fortsat kan blive aflyst fra amerikansk side. 'Det kommer an på, hvordan genforhandlingen går', siger Trump som regel - uanset, at en aflysning af NAFTA de facto ville føre til en $ø$ konomisk katastrofe for den amerikanske økonomi, der især ville ramme de republikanske nøglestater og dermed Trumps egen vælgerbase. Noget som en lang række republikanske kongresmedlemmer samt præsidentens egne sikkerhedspolitiske rådgivere længe har forsøgt at overbevise ham om; men som det økonomiske magasin Forbes skriver, så kræver det kun, at Trump 'en gang for meget lytter til sit eget dårlige instinkt og de hviskende protektionistiske stemmer i hans øre', før det kan gå galt.

På positivlisten, set med vestlige briller, har Trump optrappet retorikken over for terrorgruppen Islamisk Stat (IS) og gennemført flere bombetogter, om end med begrænset effekt. Hans tilhængere roser ham imidlertid for at have vist handlekraft - noget som præsident Obama ofte er blevet kritiseret for at mangle, især når det gælder Syrien, som da den syriske leder Assad overskred den daværende præsidents berømte 'røde linje' i foråret 2013 og anvendte kemiske våben mod sin egen befolkning.

Da det skete igen i april 2017, beordre- 
I den mere specifikke krig mod terror anses Trumps egen hårde retorik for at være en svaghed i hans egen efterretningstjeneste, der nu som før er af den overbevisning, at udsagn som "islam hader os" - som præsidenten eksempelvis udtalte i et interview under valgkampen til CNN's Anderson Cooper - blot er med til at skabe en stemning, der opildner til antiamerikanisme og radikalisering.

de Trump en syrisk luftbase bombet. Han har også bebudet en hårdere kurs i Afghanistan og optrappet USA's forsvar for den hårdt pressede regering i Kabul, hvilket stod klart, da han i august 2017 fremlagde Amerikas nye strategi for det sydlige Asien og Afghanistan. Lige den del af Trumps handlemønster er man godt tilfreds med i Pentagon - at alt ikke skal cleares i Det Hvide Hus men kan overlades mere til generalerne. Som Trump udtrykte det, under fremlæggelsen af førnævinte nye strategi: "Micromanagement from Washington D.C. does not win battles".

Endelig er der den overordnede globale strategi over for Rusland og Kina samt den fortsatte 'krig mod terror.' Trump selv nævner stort set aldrig Rusland - fx var USA's traditionelle geostrategiske fjende notorisk fraværende i præsidentens første State of The Union-tale i februar 2018 - mens Kina stort set kun fremhæves som en konkurrent $i$ handelssammenhænge og et nyttigt instrument, når det gælder presset på det nordkoreanske regime.

I den mere specifikke krig mod terror anses Trumps egen hårde retorik for at være en svaghed $i$ hans egen efterretningstjeneste, der nu som før er af den overbevisning, at udsagn som 'islam hader os' - som præsidenten eksempelvis udtalte i et interview under valgkampen til CNN's Anderson Cooper -blot er med til at skabe en stemning, der opildner til antiamerikanisme og radikalisering.

I Pentagon arbejder man imidlertid på en strategi, der bevæger sig væk fra den snævre 'krig mod terror' og over mod en mere traditionel og nationalstatsligt orienteret linje, der koncentrerer sig om truslen fra de traditionelle geostrategiske modstandere, Rusland og Kina.

\section{Fokus på Rusland og Kina}

Som ugemagasinet The New Yorker skriver i en artikel med titlen 'Trump's Pentagon Tries to Move on from the War on Terror' om den seneste forsvarsstrategi, der blev fremlagt af forsvarsminister Jim Mattis i slutningen af januar 2018, så er det "den strategiske konkurrence mellem stater, der er vores primære bekymring, når det gælder den nationale sikkerhedsstrategi, ikke terrorisme. Mens hundredetusindvis af amerikanere bekæmper religiøse fanatikere i ørkenen, bygger kineserne og russerne nye raketter og satellitter."

Magasinet citerer Doug Wise, en tidligere 'paramilitary and operations officer' for CIA, der senere blev vicedirektør for the Defense Intelligence Agency, for synspunktet om at "counterterrorism missions were critical, but came with a cost. The deaths caused by suicide bombers and maniacs who shoot up night clubs were terrible tragedies but in the end can ISIS destroy the American way of life? Probably not". Og videre, også fra Wise: "You want to talk about an existential threat? How about China's hypersonic glide missile, which can travel at multiple times the speed of sound and could take out an aircraft carrier before you could even blink? If the entire Pacific Fleet was at the bottom of the Pacific Ocean, that would pose an existential threat." 
Det er imidlertid en strategi, hvor 'apparatet' sandsynligvis hiver i Trump - eller gennemfører den, uden at præsidenten er klar over hele linjen.

\section{The Jacksonians vender tilbage}

Er det muligt at forstå Trump i teoretiske termer som en del af amerikansk udenrigspolitisk historie? Ja, svarer Walter Russel Mead, der i april-nummeret af tidsskriftet Foreign Affairs diskuterer, hvad han kalder 'the Jacksonian Revolt' eller den amerikanske populismes oprør mod den liberale verdensorden.

\section{$\square$ Donald Trump var imidlertid ene om at forstå, hvad den store folkelige bevægelse $\mathrm{i}$ USA bunder $i$, anfører Mead; det var ikke 'Jeffersonian minimalism' men 'Jacksonian populist nationalism'. Denne nationalsindede populisme har en stærk klangbund $\mathrm{i}$ dele af det amerikanske samfund især i de tradi- tionelle rustbæltestater og $\mathrm{i}$ det midt vestlige Amerika.}

Mead nævner først de to hovedskoler i international politisk teori, der har domineret amerikansk udenrigspolitisk tænkning efter Anden Verdenskrig, 'the Hamiltonians' og 'the Wilsonians', der begge ønskede USA som et center for opbygningen af en liberal verdensorden. Hvor førstnævnte så verden gennem økonomiske briller, var sidstnævnte mere optaget af at opnå fred gennem promovering af menneskerettigheder, demokratisk regeringsførelse og etablering af retsstater. I de sidste faser af og efter afslutningen på den kolde krig, splittede sidstnævnte sig op $\mathrm{i}$ henholdsvis 'liberale institutionalister' over for 'neokonservative'. Men uanset de betydelige ideologiske divergenser mellem skolerne, så var der altid en fælles agenda: ønsket om at skabe en 'global orden' med USA i centrum.

Det er imidlertid dette fælles ståsted, der nu er under angreb og vakler, fastslår Mead og det er derfor, at vi nu ser de to skoler, der var førende før Anden Verdenskrig, vende tilbage til den globale arena: 'The Jeffersonians' og 'the Jacksonians'. Førstnævnte inkluderer vore dages såkaldte 'realister', der argumenterer for, at det simpelthen vil være billigere, mindre risikabelt og mere effektivt for USA at føre en lavere global profil, men også den libertarianske skole i det republikanske parti med prominente stemmer som senatorerne Rand Paul og Ted Cruz, der begge er fortalere for, at Amerika kun skal intervenere globalt, når der er tale om direkte trusler mod USA's nationale sikkerhed.

Donald Trump var imidlertid ene om at forstå, hvad den store folkelige bevægelse i USA bunder i, anfører Mead; det var ikke 'Jeffersonian minimalism' men 'Jacksonian populist nationalism'. Denne nationalsindede populisme har en stærk klangbund i dele af det amerikanske samfund især i de traditionelle rustbæltestater og $\mathrm{i}$ det midt vestlige Amerika, der er hårdest ramt af jobs, der forsvinder, mestendels grundet den teknologiske udvikling, men som oftest finder syndebukken i 'globaliseringen' og indvandring fra især Mexico - to af kerneområderne i Donald Trumps succesrige valgkamp.

Denne specifikke populisme, der giver sig udtryk i et klart identitetspolitisk opsving i nutidig amerikansk politik, har rødder i USA's første populistiske præsident, Andrew Jackson. For de såkaldte Jacksonians er USA ikke "en politisk enhed, der er skabt og defineret gennem en række intellektuelle begreber og en uni- 
versalisme der er hentet fra Oplysningstiden", skriver Mead og fortsætter: "snarere er USA en nationalstat af amerikanere, og missionen ligger i hjemlandet."

\section{Amerikanerne og kernelandet}

Ergo ser the Jacksonians ikke den berømte amerikanske exceptionalisme som en funktion af USA's universelle forpligtelse over for omverdenen, men som USA's enestående forpligtelse til at skabe lighed og værdighed for amerikanerne. Derfor er man naturligvis heller ikke specielt interesseret i udenrigs- og sikkerhedspolitik i dette segment af vælgerne, med mindre det amerikanske homeland er under angreb.

Herfra kan man forstå stort set hele det oprør mod 'politisk korrekthed' og den liberale elite, som Trumps vælgere så passioneret deler med præsidenten. Set med disse vælgeres øjne har eliten i den grad svigtet amerikanerne til fordel for en universel ambition om at gøre verden til et bedre sted. Derfor er de upatriotiske og moralsk anløbne, de har ikke sat 'country first', som Trump også ofte anfører. Og derfor støtter Trumps vælgere instinktivt også politiet og hæren, fordi vi her har at gøre med institutioner, der forsvarer 'kernelandet'.

Men denne hær skal derfor heller ikke ofre sine unge amerikanske soldaters liv for at gøre andre lande til bedre steder, ligesom støtten til 'the second amendment' - retten til at bære våben - også er essentiel for Jacksonians. Den anden forfatningstilføjelse er oprindeligt grundlagt i folkets ret til at forsvare sig mod statens overgreb, og derfor er denne ret for mange vælgere essentiel som en frihedsrettighed.

Heraf kan man også videre forstå foragten over for internationale institutioner og den udbredte skepsis over for USA's el- lers så beundrede bedste universiteter. For netop her har hyldesten af etniske, racemæssige, kønsmæssige og religiøse minoriteter floreret $\mathrm{i}$ årevis i den internationale og liberale multikulturalismes navn - $\mathrm{fx}$ gennem kultur- og kønsstudier inden for emner, der centrerer sig om African Americans, Hispanics, Gender Studies, the LBTGQ Community, Native Americans og Muslim Americans.

Trumps kernevælgere genkender intet i disse termer, og som Mead bemærker er der én kategori, der ikke findes og heller ikke accepteres som 'etnisk kategori', nemlig hvide amerikanere. Amerikanere med hvide/europæiske rødder - $\mathrm{fx}$ italiensk-amerikanere eller irsk-amerikanere, hvoraf der er mange - er usynliggjorte som kategori i dette akademiske identitetspolitiske scenario, og uagtet om det er reelt eller ej, så føler mange - især mænd - sig tilsidesatte, fordi det køn, der rutinemæssigt iscenesættes som minoriteten, der skal tages hensyn til, er kvinder: "Mange hvide amerikanere føler, at de lever i et samfund, hvor der konstant tales om værdien af identitet og etnisk autenticitet, der giver økonomiske og sociale fordele til alle andre end dem. Der er ikke nogen acceptable måder, hvorpå de kan fejre deres etniske rødder."

\section{Det ægte Amerika}

Her ligger roden til en forklaring af det såkaldte 'alt-right', der er den amerikanske variant af den hvide, nationalt sindede 'identitære bevægelse' i Europa, der også findes i det små i Danmark. Og her ligger også forklaringen på, at Trumps beskrivelse i sin indsættelsestale af de seneste 30 år som et 'amerikansk blodbad' på 'the forgotten men and women' gled lige ind på lystavlen til klapsalver i basen, men vakte opstandelse og bestyrtelse i Washingtons 
globale og polerede kosmopolitiske elite.

Trumps berømte mur mod Mexico ses i denne optik som et oplagt forsvar af 'det ægte Amerika' og som et forsøg på at undgå marginalisering og fremmedgørelse i en verden, hvor de ikke længere er værdsatte eller efterspurgte. Men hvad leder denne folkestemning, denne Jacksonian revolte så til i udenrigspolitikken? Det er det for tidligt at spå endegyldigt om. Dels fordi Trump som nævnt indledningsvis netop omgiver sig med et meget stærkt og indflydelsesrigt hold af generaler, der er hentet $\mathrm{i}$ henholdsvis traditionel Wilsonian og Hamiltonian tankegang. Dels fordi der også findes nationale interesser, som Trump ikke er hævet over.

Men når Trumps vælgere instinktivt vender sig mod handelsaftaler, der ikke har skabt nye jobs for dem, eller føler, at globaliseringen nok har ført til øget profit men ikke til bedre lønninger, har disse vælgere en pointe. Derfor er udfordringen i international politik nu heller ikke så meget et abstrakt forsøg på at 'genskabe den liberale verdensorden', som det er at skabe sikkerhed blandt befolkningerne i nationalstaterne om, at resten af verden ikke er et ondt sted fyldt med fjender, men at man kan vinde på at samarbejde og $\mathrm{fx}$ handle med sin omverden.

Så længe den uregulerede kapitalisme ses som en trussel mod selve den socioøkonomiske model, der historisk lå til grund for freden efter Anden Verdenskrig, så vil illiberale modeller - ikke bare de henholdsvis højre- og venstrepopulistiske agitatorer, vi ser vinde frem også i Vesteuropa, men også ægte autokratier som i Rusland eller diktaturer som i Kina - vokse.
Med andre ord bygger man ikke nogen ny liberal verdensorden, hvis det kun er eliten, der kan se og mærke fordelene.

Og lige nu kan Trumps kernevælgere ikke se fordelene ved den traditionelle amerikanske udenrigspolitik. Det betyder ikke, at denne er på vej til at forsvinde som sagt er der stærke kræfter, der trækker i traditionel retning, også i Trumps egen lejr. Men det betyder, at fundamentet under den er blevet svagere. Hvilket igen kan føre til en verden uden et tydeligt amerikansk lederskab.

Og skulle denne svækkelse blive endnu tydeligere, vil 'G7-landene stå uden ledelse og risikere at blive irrelevant som gruppe', som Stewart M. Patrick skriver i artiklen, 'Trump and World Order' i Foreign Affairs. Det kunne også føre til, at den større gruppe af økonomisk stærke lande, G20, ville se mod Beijing, mens BRIKS-landene (Brasilien, Rusland, Indien, Kina og Sydafrika) ville vinde en langt større indflydelse.

For et land som Danmark, hvor demokrati, menneskerettigheder og markeds$ø$ konomi trives inden for en retsstatslig ramme, ville en sådan udvikling være entydig negativ. Vi har derfor både meget at vinde og meget at tabe ved en fortsat erosion af den traditionelle amerikanske udenrigspolitik. Og blandt andet derfor er det nok ikke helt forkert at gætte på, at man i København - både i Prins Jørgens Gård og på Asiatisk Plads - håber på, at generalerne holder deres musketer-ed og ikke viger fra Trumps side hverken nu eller frem mod næste valg i 2020. 


\section{Danmarks udenrigs- og sikkerhedspolitiske strategi: Less is more}

\section{Af Jakob Dreyer}

Regeringen præsenterede sidste år Danmarks første udenrigs- og sikkerhedspolitiske strategi, der i en usikker tid søger at skabe en mere samtænkt og prioriteret politisk indsats på området. Strategien lever dog ikke op til målsætningen, da den ikke præsenterer en sammenhængende vision. Dens fem indsatsområder er så brede, at Danmark dårligt kan påvirke dem alle væsentligt.

For at skabe en mere sammenhængende, alliancebaseret og prioriteret strategi kan man lade sig inspirere af det politiske europakort, hvor fire udenrigs- og sikkerhedspolitiske hovedveje tegner sig: En transatlantisk, en visegradsk, en kontinental og en nordisk. Vejene ikke er gensidigt udelukkende, men søger man at tage dem alle, kommer man ingen vegne.

Nationale sikkerhedsstrategier som genre stammer fra USA, hvor Ronald Reagans regering i 1986 offentliggjorde den første af sin slags. Her blev regeringens sikkerhedspolitiske vision præsenteret for Kongressen samt den amerikanske og internationale offentlighed. Siden har skiftende amerikanske regeringer udgivet na- tionale sikkerhedsstrategier, hvilket har været et værdifuldt redskab til at skabe sammenhæng i den siddende regerings politik og har sat sikkerhedspolitik på dagsordenen i den offentlige debat.

Sikkerhedsstrategierne har siden udgjort grundlaget for vigtige og kontroversielle politiske debatter, og eksempelvis blev den såkaldte Bush-doktrin skitseret i strategien fra 2002, hvor ideen om 'pre-emptive strikes' blev præsenteret og efterfølgende taget i anvendelse mod Saddam Husseins regime i Irak.

Også den nuværende Trump-regering, har præsenteret sin sikkerhedspolitiske strategi, der bygger på fire hovedpunkter: Beskyt Amerika, promover amerikansk velstand, bevar fred gennem styrke og udbyg amerikansk indflydelse. Dermed sætter strategien en målsætning, som både den amerikanske Kongres og offentligheden kan tage stilling til.

Hvad kan vi i Danmark lære af den amerikanske tradition for nationale sikkerhedsstrategier? Sikkerhedsstrategierne sikrer indadtil, at diplomatiet og regeringen i højere grad harmoniserer deres udenrigs- og sikkerhedspolitiske arbejde. Udadtil giver det offentligheden mulig- 
hed for at tage stilling til den udenrigspolitiske linje, hvorved den demokratiske samtale på området styrkes.

Denne rolle kan de danske udenrigsog sikkerhedsstrategier også få, men en væsentlig forskel er, at Danmark som småstat har begrænsede ressourcer og er afhængig af alliancer for at realisere sine politiske ambitioner. Derfor vil en velfungerende dansk strategi være nødt til at udvælge og afgrænse sine strategiske fokusområder med langt større omhu og lægge mere vægt på alliancepolitik, end USA behøver. Lever den danske regerings udenrigs- og sikkerhedspolitiske strategi op til disse kriterier?

"Rammerne for Danmarks udenrigsog sikkerhedspolitiske interessevaretagelse er udfordret. De tektoniske plader, som dansk udenrigspolitik har hvilet på i mange år, er i bevægelse."

Med denne dramatiske indledning sættes rammen for Danmarks første udenrigs- og sikkerhedspolitiske strategi, der skal søge at skabe en mere prioriteret og samtænkt udenrigs- og sikkerhedspolitik. Baggrunden for dette initiativ var ambassadør Taksøe-Jensens udredning om dansk udenrigspolitik fra 2016, der foreslog, at regeringen udarbejdede en strategi, som kunne bringe Danmark på forkant med den internationale udvikling, og udvalgte fem prioriterede fokusområder.

Regeringen fulgte dog kun delvist rådene fra ambassadør Taksøe-Jensen, da hans to separate forslag om henholdsvis udarbejdelsen af en strategi samt udvælgelsen af fem fokusområder blev kombineret. Derfor udgøres strategidokumentet af både en overordnet strategi og fem 'prioriterede indsatsområder'. Strategien struktureres primært efter de fem indsatsområder, hvilket medfører, at den overordnede strategiske vision træder i baggrunden.

Det nærmeste, strategien kommer på at præsentere regeringens overordnede visioner, er i indledningen, hvor internationalt samarbejde, en sikker, fredelig og velstående verden, regelbaseret samarbejde for alle lande, demokrati og frihed samt succesfulde internationale virksomheder nævnes som målsætninger. Som det fremgår er målene brede, vage og ikke-prioriterede, hvorfor de ikke giver en klar ide om regeringens politiske prioriteter. På det alliancepolitiske område er det heller ikke nemt at udlede regeringens prioriteter ud fra strategien. Danmark skal både engagere sig i EU, NATO, FN og WTO, fastholde sit tætte forhold til USA og Tyskland samt søge nye alliancepartnere i Europa i kølvandet på Brexit.

Med andre ord ønsker regeringen, at vi skal blive ved med at gøre alt det, vi gør i forvejen - og mere til. De fem fokusområder: 'Migration, ustabilitet og terrorisme; Sikkerhed i nærområdet; Brexit og EU's fremtid; Globalisering - økonomisk og teknologisk diplomati; Arktis', som rapporten er struktureret efter, er ligeledes så store, at Danmark ikke har en jordisk chance for at gøre en væsentlig forskel på alle fem.

Det, der skulle have været en strategi for at opnå en mere visionær, samtænkt og prioriteret indsats, er således formuleret i så generelle vendinger, at snart sagt alle danskere kunne støtte dem. Herved udgør strategien hverken en politisk vision, som kan bruges til at prioritere Danmarks begrænsede ressourcer, eller et grundlag for en offentlig politisk debat om dansk udenrigs- og sikkerhedspolitik. Disse mangler afspejles også i oppositionens reaktioner. 


\section{Fogh Rasmussens militære aktivisme}

For at forstå de strategiske veje Danmark kan gå, er et naturligt udgangspunkt Danmarks nuværende udenrigs- og sikkerhedspolitiske ståsted. Danmarks position internationalt er i høj grad et produkt af Fogh Rasmussen-regeringen, hvis politiske linje er det tætteste Danmark er kommet på en klar udenrigs- og sikkerhedspolitisk strategi i nyere tid.

Danmarks aktive udenrigs- og sikkerhedspolitik har rødder tilbage til det store danske engagement for at integrere de baltiske lande i NATO efter den kolde krig og den danske krigsindsats under Balkan-krigene.

Men under Fogh Rasmussens regering placerede Danmark sig tættere på USA og Storbritannien end noget andet land i Kontinentaleuropa. Forud for at Danmark gik ind i Irak- og Afghanistankrigene, formulerede Anders Fogh Rasmussen en klar (om end ikke formaliseret) sikkerhedspolitisk strategi. Strategien byggede på militær aktivisme, der prioriterede støtten til USA's terrorbekæmpelse og demokratifremme med (primært) militære midler højere end multilateralisme og europæiske alliancehensyn.

Fogh Rasmussen forbandt ligeledes strategien med et angreb på Danmarks tidligere samarbejds- og fodnotepolitik, ligesom beslutningen om at støtte Irak-invasionen på et snævert folketingsmandat uden støtte fra FN brød med traditionen om, at krigsindsatser skulle bero på bred støtte fra Folketinget og internationalt.

I forlængelse af Foghs vision bidrog Danmark stort til Irak- og Afghanistankrigene, hvilket havde store menneskelige og materielle omkostninger. Krigene betragtes i dag som fejlslagne og har haft store negative konsekvenser for regerin- gerne Blair og Bushs eftermægle. Selvom Danmark ikke har haft det samme opgør med disse operationer, tog man til en vis grad ved lære af krigene, og smagen for store landoperationer for demokrati og frihed er blevet afløst af flybidrag, specialstyrkeoperationer og rådgivning, hvilket Danmark stadig bidrager med i kampen mod Islamisk Stat.

Danmark har dog overordnet holdt fast i den militære aktivisme og det tætte partnerskab med USA og Storbritannien, og både den nuværende og tidligere regeringer har brystet sig af Danmarks meget store internationale militære bidrag relativt til landets størrelse.

\section{Opvågnen fra den aktivistiske drøm}

Den militære aktivisme har dog haft sin pris. Danmarks militære samarbejde med USA og Storbritannien er blevet implementeret på bekostning af andre udenrigspolitiske områder. På det militære område opgav Danmark praktisk talt det territorielle forsvar for at få råd til de internationale missioner uden at øge forsvarsudgifterne. Ligeledes nedprioriteredes de nordiske og kontinentaleuropæiske alliancer, hvilket på det seneste er blevet forstærket af, at de øvrige EU-lande med undtagelse af Storbritannien, Danmark og Malta har taget initiativ til en forsvarsfond og et struktureret forsvarssamarbejde, som Danmark ikke kan deltage i grundet sit forsvarsforbehold.

Da Danmark siden Fogh Rasmussen-æraen således har kastet alle sine sikkerhedspolitiske æg i den transatlantiske kurv, er det en vægtig undladelsessynd i strategien, at den ikke forholder sig til Trump-regeringens udenrigs- og sikkerhedspolitik. Det er ellers en klar udfordring for Danmark, at Trump-regeringen ønsker, at USA skal tage mindre glo- 
balt ansvar og have mere fokus på landets mere snævre udenrigs- og sikkerhedspolitiske interesser.

Selvom udenrigsminister Anders Samuelsen har kritiseret den amerikanske præsident ved flere lejligheder, har regeringens grundlæggende holdning til Trumps America First-agenda været, at 'præsidenter kommer og går, men at Danmarks alliance med USA består', som udenrigsministeren for nyligt udtalte det. Dette perspektiv bygger dog på en for simpel præmis om, at valget står mellem at fastholde eller droppe alliancen med USA.

Det klare flertal både i den danske befolkning og på det politiske niveau ønsker, at Danmark skal fastholde sin alliance til USA, og anser den amerikanske sikkerhedsgaranti som væsentlig for dansk sikkerhed. Inden for denne overordnede ramme er der dog et stort udenrigspolitisk handlerum, som Danmarks strategi og alliancepolitik kan basere sig på. For at forstå Danmarks muligheder er det relevant at analysere fire hovedstrømninger, der karakteriserer europæisk politik netop nu.

Selvom Danmark ikke behøver at begrænse sig til én af disse veje, kan man ikke bygge en sammenhængende strategi på dem alle. De fire retninger kan beskrives som henholdsvis den transatlantiske, den visegradske, den kontinentale og den nordiske.

\section{Danmarks transatlantiske fokus}

Med Brexit har ikke bare USA, men også Storbritannien bevæget sig i en mere nationalistisk retning. Briternes udtræden fra EU giver udfordringer på Asiatisk Plads, da Danmark længe har lagt sig i slipstrømmen på Storbritannien ikke bare på det militære område, men også i landets liberale, pragmatiske og skeptiske EUkurs. Situationen gøres sværere af, at Stor- britannien i den kommende tid skal bruge store dele af sine diplomatiske ressourcer på at forhandle vilkårene for sin udtræden af unionen.

De nationalkonservative strømninger, som Brexit og præsident Trump repræsenterer, vækker dog en vis genklang i Danmark. Dér har villigheden til at udfordre den europæiske menneskerettighedsdomstol, FN's kvoteflygtningesystem og opgøret med UNRWA (der er ansvarlig for støtte til palæstinensiske flygtninge) eksempelvis fået opbakning fra Socialdemokratiet til Dansk Folkeparti.

Blandt udfordringerne ved fortsat at basere udenrigspolitikken på dette partnerskab er dog, at præsident Trumps primære interesse i europæisk samarbejde hidtil har begrænset sig til et krav om øgede forsvarsbidrag blandt de europæiske NATO-medlemmer. Dette har Danmark allerede imødekommet med sin udsendelse af tropper til Baltikum og et løft til forsvarsbudgettet - herunder det territorielle forsvar - i forbindelse med forsvarsforliget for 2018-23.

Herudover er udfordringen ved et meget tæt transatlantisk samarbejde netop nu, at det er uklart, hvad man præcis kommer til at samarbejde om som følge af Trump-regeringens skiftende udmeldinger og hyppige enegang. Da Storbritannien melder sig ud af EU, kan Danmark heller ikke længere basere sin EU-politik på det tætte forbund med briterne, om end det tætte bilaterale samarbejde med briterne på især forsvarspolitikken kan bestå også efter Brexit.

\section{Visegrad}

Derfor kan Visegrad-landene, der siden Brexit er blevet dagsordenssættende for den EU-skeptiske og transatlantiske fløj i unionen, vise sig som potentielle nye 
samarbejdspartnere, såfremt Danmark også i EU ønsker at fortsætte i en nationalkonservativ retning.

Det vakte opsigt, da Dansk Folkepartis udenrigsordfører Søren Espersen i december 2017 roste Ungarn, Polen, Tjekkiet og Slovakiet for deres forsvar af 'kristen frihed' og kamp mod 'centralstyret unionisme og meningstyranni'. Visegrad-landene kan i forlængelse af denne agenda blive samarbejdspartnere i den kritiske kurs over for flygtninge og indvandrere og i udfordringen af den europæiske menneskerettighedsdomstols dynamiske fortolkninger, der ifølge strategien "bliver et vigtigt fokus, når Danmark til efteråret overtager formandskabet for Europarådet."

Visegrad-landene er også naturlige samarbejdspartnere i opgøret med FN's kvoteflygtningesystem i forlængelse af, at de borgerlige partier og Socialdemokraternes har stoppet Danmarks faste bidrag til FN's system for kvoteflygtninge.

Særligt Ungarn og Polen er dog samtidig blevet mødt med stor kritik fra særligt de vesteuropæiske EU-lande for deres autoritære reformer, der ifølge EU både truer landenes ytringsfrihed, deres domstoles uafhængighed og mindretalsrettighederne. I forlængelse heraf vil et tættere samarbejde med disse lande være svært at kombinere med en ledende position i menneskerettighedsspørgsmål, som regeringen ellers nævner som en målsætning i strategien, og som tidligere har været en central dagsorden for Danmark.

\section{Kontinentaleuropa i bevægelse}

Ønsker regeringen derimod at tage en mere liberal, internationalistisk kurs, må den se længere mod vest, hvor det fransk-tyskledede europæiske samarbej- de har fået momentum i kølvandet på Brexit og præsident Trumps tiltræden.

Støtten til EU både på det politiske niveau og blandt Europas befolkninger er i kølvandet på valget af præsident Trump og Brexit-afstemningen steget markant.

Denne udvikling har medført, at EU med bred opbakning og under tysk-fransk lederskab har igangsat flere initiativer på det udenrigs- og sikkerhedspolitiske område end nogensinde før.

Både regeringen og - ifølge meningsmålinger - et stort flertal i befolkningen ønsker, at Danmark skal deltage i forsvarssamarbejdet, men forsvarsforbeholdet udelukker denne mulighed. Et alternativ er dog, som det er blevet foreslået af præsident Emmanuel Macron, at bidrage aktivt til den nye europæiske interventionsstyrke, hvor Danmark kan bringe sin internationale militære erfaring i spil.

På et mere overordnet niveau er der ligeledes mulighed for bidrage yderligere til det europæisk forsvarssamarbejde også i NATO og bilateralt.

Ønsker man at prioritere den kontinentale vej, bliver det dog på længere sigt svært ikke at tage et opgør med EU-forbeholdene i almindelighed og forsvarsforbeholdet i særdeleshed. Ligeledes ville det på et mere grundlæggende niveau kræve, at Danmark opgav sin instrumentelle 'noget-for-noget' tilgang til EU og i stedet mere uforbeholdent støtter det europæiske samarbejde. Derfor kan en kontinentaleuropæisk tilgang dårligt kombineres med et tættere samarbejde med Visegrad-landene.

\section{Øget nordisk samarbejde?}

Danmarks udenrigspolitiske strategi kan også bygge på en tilbagevenden til tidligere tiders tætte nordiske samarbejde.

Da Danmark sammenlignet med Nor- 
ge og Sverige har mindsket udgifterne til udenrigstjenesten og ulandsbistand, bruger Sverige og Norge både absolut og relativt til BNP flere ressourcer end Danmark på disse områder.

Danmarks to nordiske søsternationer har i forlængelse heraf kunnet tage mere lederskab i eksempelvis FN's udvikling af fredsopbyggende indsatser samt fredsforhandlinger og i spørgsmål om kvinders rettigheder. Ikke dermed sagt at Danmark ikke støtter disse dagsordener, men lederskab kræver både økonomiske og politiske ressourcer, som Danmark har været mindre villig til at afsætte.

Såfremt Danmark ønsker at basere sin udenrigspolitiske strategi på en nordisk model, kræver det derfor flere økonomiske ressourcer til de områder, hvor Danmark ønsker at påtage sig et særligt globalt lederskab. Lige så vigtigt er dog den politiske vilje, og med beslutningen om at Danmark skal have et pusterum fra sit bidrag til FN's kvoteflygtningesystem, bliver det et område, hvor Danmark får dårligere mulighed for at tage internationalt lederskab.

I EU bidrager flygtningespørgsmål også til, at kløften mellem Danmark og de nordiske lande er vokset. Det sås eksempelvis, da Sverige, Island og Norge kritiserede, at Danmark havde udfordringen af den europæiske menneskerettighedsdomstol som hovedprioritet for sit formandskab i Europarådet.

Et andet område, hvor Danmark har mulighed for at udvide sit samarbejde med de andre nordiske lande, er miljø- og klimaspørgsmålet, hvor regeringen med sit P4G-initiativ har forsøgt at tage globalt lederskab. Dette er et naturligt område for Danmark, da man historisk har taget en ledende rolle i den grønne omstilling og har en stor industri inden for bæredygtig teknologi.

I den kontekst er det usammenhængende, at regeringen ikke har prioriteret det grønne område som et indsatsområde i sin strategi, ikke har et rent miljø- og klimaministerium og har skåret i forskningen i grøn energiteknologi og klimabistand. Hvis man fremadrettet ønsker at tage lederskab på dette område sammen med de andre nordiske lande, vil det have en større effekt, hvis der afsættes flere økonomiske og politiske ressourcer, og det gøres mere helhjertet.

\section{Kill your darlings}

Ifølge den britiske professor i krigsstudier Lawrence Freedman handler strategi om at få mere ud af en situation, end den givne magtrelation lægger op til. Forudsætningen for, at Danmarks udenrigs- og sikkerhedspolitik kan leve op til dette, er, at de fremtidige udenrigs- og sikkerhedspolitiske strategier formulerer en klar politisk målsætning samt prioriterer og afgrænser de politikområder, man ønsker at påvirke.

De fire udenrigspolitiske veje - den transatlantiske, den visegradske, den kontinentaleuropæiske og den nordiske - skitserer de udenrigs- og sikkerhedspolitiske veje, Danmark kan gå. For at fremtidige strategier kan sikre, at Danmark får mere indflydelse end landets størrelse retfærdiggør, kræver det politisk mod til ikke blot at tilvælge, men også fravælge udenrigspolitiske prioriteter. 


\section{En højteknologisk sikkerhedspolitik}

Af Mathias Terp Jensen

Danmark er et af de mest teknologisk udviklede lande i verden. Vi anvender digitale løsninger i vores infrastruktur og dagligdag, og dansk rumfartsindustri omsætter for milliarder. Vores teknologiske begejstring og innovation skaber velstand og muligheder for Danmark. Men det skaber også en række sikkerhedspolitiske udfordringer, der ændrer de grundlæggende vilkår for sikkerhedspolitikken og kræver et strategisk svar.

Den teknologiske udvikling har flere gange ændret rammerne for udenrigsog sikkerhedspolitik. Oceangående skibe muliggjorde fra det 16 . århundrede nye handelsruter og koloniseringen af fjerntliggende nationer. I det 18. århundrede skabte udviklingen i tekstil- og jernindustrien grundlaget for den industrielle revolution, der markant forskød den økonomiske fordel til Vesten. Endnu senere skabte spredningen af atomvåben en ny strategisk dynamik mellem stormagterne.

I det 21. århundrede er turen til at forandre udenrigs- og sikkerhedspolitikken kommet til teknologien i cyberspace og det ydre rum. Den teknologiske udvik- ling på dette område har gjort kommunikation hurtigere, velstanden større og militære operationer mere præcise. Men vores afhængighed af cyberspace og det ydre rum udfordrer også den traditionelle forståelse af suverænitet og afskrækkelse. Samtidig ændrer det trusselsbilledet mod Danmark markant.

Den kendte strateg Lawrence Freedman definerer strategi som 'kunsten at skabe magt'. Som en lille stat med begrænsede midler er det derfor afgørende for Danmark at udvikle en strategi på området. Hvis Danmark skal fortsætte med at 'slå over vores vægtklasse', som skiftende amerikanske præsidenter har yndet at sige, i det 21. århundredes udenrigs- og sikkerhedspolitik, er det afgørende at prioritere de teknologiske områder, der kommer til at forme rammerne for sikkerhedspolitikken: cyberspace og det ydre rum.

\section{Teknologisk afhængighed}

Vi er utrolig afhængige af teknologien i cyberspace og det ydre rum. Ifølge Danmarks Statistik bruger 85 pct. af danskerne internettet hver dag. Hvad enten det er igennem emails på arbejdspladsen, fredagsfilmen fra Netflix eller vores kri-

Mathias Terp Jensen er bachelor i statskundskab ved Københavns Universitet. I øjeblikket studerer han til kandidat i International Affairs på Sciences Po i Paris og London School of Economics. 
tiske infrastruktur er cyberspace en del af vores liv. Det er satellitter og rumteknologi også. Medier anvender kommunikationssatellitter, navigationssystemer og hæveautomater trækker på GPS-systemet, og når vejrudsigten en sjælden gang passer, skyldes det vejrsatellitter.

Afhængigheden gælder også for forsvaret. Vi sender og opbevarer fortrolige informationer i cyberspace, og flere af vores forsvarssystemer er afhængige af cyber- og rumteknologi. Vejrsatellitter bruges til at planlægge operationer, overvågningssatellitter til at vælge den korrekte strategi og taktik, og GPS-satellitter bruges til at guide fly, skibe og tropper.

Samtidig har Danmark opnået store velstandsgevinster grundet vores evne til udvikle løsninger inden for cyberspace og det ydre rum.

Danske it-virksomheder omsætter for flere hundrede milliarder, og i kommercialisering af det ydre rum er danske virksomheder med langt fremme. Betydningen af teknologien for Danmarks udenrigs- og sikkerhedspolitik understreges desuden af udpegningen af verdens første digitale ambassadør, som har hovedsæde tæt ved Silicon Valley.

Den amerikanske general Kevin Chilton kalder det amerikanske militær for afhængigt af det ydre rum. Det gælder også for det danske samfund og dets udenrigs- og sikkerhedspolitik. Af den årsag udgav regeringen også en national strategi for rummet i 2016, ligesom at der snart forventes en ny cyberstrategi til at afløse den sidste fra 2014.

Det er dog afgørende, at disse strategier også tænkes ind i den bredere udenrigsog sikkerhedspolitiske strategi. For netop vores afhængighed af cyberspace og det ydre rum er med til at øge trusselsbilledet mod Danmark.

\section{Et barn af globaliseringen}

For at kunne forstå de udenrigs- og sikkerhedspolitiske udfordringer, der er forbundet med cyberspace og det ydre rum, er det afgørende at forstå et helt centralt element: Cyberspace og det ydre rum respekterer ikke landegrænser. På den måde bliver de teknologiske muligheder i cyberspace og det ydre rum på mange måder en inkarnation af globaliseringen. Cyberspace og satellitter er i deres natur grænseoverskridende og synes at understrege, at selv det, der sker på den anden side af jordkloden, påvirker os. Det udfordrer grundlæggende vores forståelse af suverænitet.

Et af de helt grundlæggende elementer i suverænitet er statens uafhængighed af andre. Men både i cyberspace og $\mathrm{i}$ det ydre rum er det langt fra sandheden. I cyberspace risikerer Danmark utilsigtet at blive ramt af cyberangreb i form af en virus.

Da USA og Israel i et forsøg på at forsinke Irans atomvåbenudvikling inficerede iranske computere med den såkaldte Stuxnet-virus, holdt den sig ikke pænt inden for Irans grænser, men spredte sig til computere i en række forskellige lande - herunder USA selv. Det samme gjorde det nordkoreanske ransomware-angreb WannaCry, der blev mest berygtet for i 2017 at kryptere britiske sundhedsdata og kræve løsepenge for at give adgang til dem.

Afhængigheden af andre lande gælder også i det ydre rum. Danmarks brug af det ydre rum er næsten udelukkende bundet op på amerikanske, europæiske og internationale satellitsystemer. Juridisk tilhører det ydre rum ikke nogen stater, men kan benyttes af alle til fredelige formål. Danmark opererer også enkelte satellitter selv. 
De seneste år har en eksplosion i interessen for rummet dog gjort det trangt med plads, og rumaffald er blevet en trussel for danske interesser. Rumaffald er hele eller dele af gamle satellitter eller anden rumteknologi, der stadig opholder sig i det ydre rum, og som risikerer at kollidere med og ødelægge vitale satellitter. Det skabes både som en naturlig sideeffekt af øget aktivitet og missilangrebsøvelser på satellitter som Kinas i 2007. Der er for øjeblikket ca. 23.000 stykker sporet rumaffald. Til sammenligning er der ca. 1.200 satellitter.

Den gode nyhed er, at en lang række lande anerkender den grænseoverskridende natur af cyberspace og det ydre rum. Specielt cyberspaces grænseoverskridende natur fremhæves i EU's og USA's cybersikkerhedstrategier. Det understreger, at afhængigheden gælder for alle lande. Suveræniteten forsvinder således ikke for Danmark, den deles med resten af verden. Det indbefatter, at den bedste måde at regulere cyberspace og det ydre rum på er internationalt.

\section{Et ændret trusselsbillede}

De teknologiske forandringer i cyberspace og det ydre rum indbefatter en række effekter på trusselsbilledet for Danmark.

For det første kompliceres trusselsbilledet af en række nye mindre aktører og trusler. Groft sagt kræver det ikke meget mere end en computer og en person med indgående viden om informations- og computersystemer for at kunne lave et cyberangreb. Afhængigt af omfanget, målet og typen kan cyberangreb kræve mere eller mindre computerkraft og sofistikeret kode, men grundlæggende er adgangsbarriererne lave.

Adgangsbarriererne til det ydre rum er også faldet drastisk i de seneste år. Kom- mercialiseringen har medført stærkt faldende priser og mindre satellitter. Det betyder, at mens der i 1966 kun var seks lande, der havde satellitter, er der nu over 40 - herunder Danmark.

Det er dog stadig både svært og dyrt at opsende egne satellitter, og det er derfor stadig stormagterne, der dominerer opsendelser af satellitter.

I modsætning til opsendelsen er teknologi til at angribe satellitter relativt billig. Der findes generelt fire former for angreb mod satellitter. Mens missilangreb og dazzling det vil sige midlertidigt at blænde en satellit med laser - både er dyre og komplicerede metoder, er cyberangreb og jamming - det vil sige at bruge elektromagnetisk energi til at overdøve satellittens signal - billige og relativt ligetil at anvende.

Den demokratisering af magtmidler giver en række mindre aktører midlerne til at true Danmark. Det gælder mest åbenlyst for hackergruppen Anonymous, der anvender cyberangreb som led i politisk aktivisme. Der har endda også været enkelte ubekræftede rapporter ude omkring Daeshs brug af jamming-angreb mod satellitter. Teknologien skaber dermed et mere komplekst trusselsbillede med flere aktører, der billigt og let kan udrette stor skade.

For det andet bliver sikkerhedspolitisk strategi baseret på mindre angreb og påvirkningskampagner. Mens NATO stadig har den klare militære fordel, anvender Kina, Rusland og Nordkorea med flere cyberspace til at skade Vesten igennem såkaldte death by a thousand cuts. Her bruges en kaskade af mindre i sig selv ubetydelige angreb til at skade Vesten i det lange løb. Den lille effekt af de enkelte angreb gør det svært at reagere kraftigt på angrebene, selvom de sammenlagt kan have store konsekvenser. 
Ydermere giver teknologien fjendtligsindede aktører mulighed for at føre påvirkningskampagner mod Danmark ved at indsamle og lække oplysninger, der er med til at undergrave det politiske system uden at bruge militær magt. Disse påvirkningskampagner, som Rusland synes at stå bag, har specielt været tydelige ved amerikanske og europæiske valg. Målet med disse kan være at skabe splid i Vestens bærende institutioner, NATO og EU, hvilket vil tillade en mere aggressiv russisk udenrigspolitik.

Derudover udnytter fjendtlige stater, at det er særdeles svært at attribuere cyberangreb korrekt. Mens missiler eller troppebevægelser typisk har en returadresse, kan cyberangreb skjules og gennemføres igennem en række kompromitterede computere i andre lande. Dermed bliver det lettere for stater som Rusland og Kina at benægte deres involvering i cyberangreb.

For det tredje giver det dem en måde at mindske NATOs militære fordel. NATOs militære fordel er i høj grad bundet op på anvendelse af teknologi. I tilfælde af en større konflikt vil det første angreb derfor sandsynligvis være rettet mod cyberspace og det ydre rum. Hvis det lykkes, kan fjenden kraftigt reducere NATOs militære styrke eller få en afgørende fordel ved at angribe den vigtige militære infrastruktur.

Som resultat af den teknologiske udvikling i cyberspace og det ydre rum bliver trusselsbilledet dermed præget af en række mindre aktører, mindre angreb og påvirkningskampagner og en potentiel svækkelse af NATOs militære fordel.

\section{Afskrækkelse i en ny tid}

At vi i nu over 70 år har undgået en Tredje Verdenskrig tilskrives af mange eksperter afskrækkelse. Helt kort handler afskrækkelse om at påvirke fjendens strategiske kalkule, således at man undgår et angreb. Det kan man gøre ved at øge truslen om gengældelse eller ved at gøre det så tilpas svært at udføre angrebet, at det ikke er besværet værd.

Under den kolde krig afskrækkede sandsynligheden for gensidig tilintetgørelse Sovjetunionen og USA fra en atomkrig. Men i cyberspace og det ydre rum er flere af de elementer af det 20. århundredes afskrækkelse fraværende.

Under den kolde krig fungerede afskrækkelse i det ydre rum som en forlængelse af atomvåbenafskrækkelsen. Det ydre rum blev udforsket og bemandet som et led i sovjetiske og amerikanske missilforsvarssystemer, der advarede om forestående atomangreb. Angreb på satellitter ville derfor være blevet anset som starten på en atomkrig og gengældt med atomvåben.

I dag er situationen mærkbart anderledes. Det ydre rum er befolket med en række mindre vigtige satellitter fra vejrtil tv-satellitter, og de færreste tror, at amerikanerne, kineserne eller russerne, vil starte Tredje Verdenskrig, hvis tv-signalet ryger. Og da angrebsteknologien er relativt billig, er der ikke meget, der afskrækker fjender fra angreb på danske interesser i det ydre rum.

På samme måde mangler der også en troværdig afskrækkelse for cyberangreb. På trods af de seneste års gentagne cyberangreb mod Europa og USA er der ikke konsensus om en række vigtige spørgsmål om afskrækkelse. Det skyldes især problemet med at attribuere angreb, da der ikke er megen afskrækkelseseffekt over at gengælde over for det forkerte land.

Samtidig gør muligheden for, at en 
række ikke-statslige aktører som Anonymous og Daesh kan bruge cyber- og rumangreb, at Danmark og NATO skal tage stilling til, hvordan man afskrækker dem. Det er nok svært at forvente, at Daesh, Al-Qaeda eller andre radikale ekstremistiske grupperinger vil lade sig afskrække af truslen om gengældelse.

Der er også problemer med at gøre det mere besværligt at angribe. Det er svært at dække alle potentielle indgange i cybersystemer, og da offensive våben er billige, risikerer en sådan strategi at ødelægge bæredygtigheden i det danske forsvarsbudget.

Det er således nødvendigt for Danmark at skabe en stærk og troværdig trussel om gengældelse mod fjendtligsindede. Men det kan kun lade sig gøre, hvis man i NATO etablerer en grundlæggende enighed om, hvor høj sikkerhed der skal være i attributionen af angrebet, samt hvilken gengældelse der vil være proportional.

Samtidig skal Danmarks defensive kompetencer styrkes for at gøre det så besværligt som muligt for mindre sofistikerede aktører, der som fx Daesh ikke kan afskrækkes, at kunne forårsage skade.

\section{Strategiske principper}

Den teknologiske udvikling inden for cyberspace og det ydre rum efterlader Danmark i en situation, hvor vi i er afhængige af resten af verden, hvor stormagterne er i konflikt, og hvor kun lidt afskrækker fjender. Det efterlader et klart behov for strategisk tænkning om dansk udenrigs- og sikkerhedspolitik på området. Jeg kommer nedenfor med mit bud på fire strategiske principper:

(1) Gør cyberspace og det ydre rum til strategiske topprioriteter i udenrigs- og sikkerhedspolitisk - specielt i forbindelse med EU og NATO.

Det absolut første skridt i løsningen på et problem er at anerkende, at det eksisterer. Cyberspace har i de senere år fået større opmærksomhed nationalt og internationalt. Det har udmøntet sig i en række nationale og internationale strategier. Der er ligeledes sat en proces i gang for at styrke NATOs afskrækkelse på cyberområdet. Den proces bør Danmark i videst mulige forstand forsøge at påvirke.

Regeringer og eksperter er også ved at få øjnene op for det ydre rums sikkerhedspolitiske betydning. Fx rummer både den amerikanske og den franske sikkerhedsstrategi afsnit om det ydre rum. I EU- og NATO-sammenhæng er der dog behov for en offensiv diplomatisk indsats for at prioritere emnet. Det kan Danmark blandt andet hjælpe på vej ved at øge sit bidrag til ESA (European Space Agency).

I EU kan det danske forsvarsforbehold dog stille Danmark ringere end andre lande, og regeringen bør derfor overveje en folkeafstemning, hvor der tages stilling til europæisk integration i udenrigsog sikkerhedspolitikken, eller i endnu højere grad satse på USA og NATO som samarbejdspartnere.

En offensiv diplomatisk indsats vil også styrke Danmarks indflydelse på begge områder, der ellers grundet deres vigtighed risikerer at blive domineret af stormagterne. Specielt på cyberområdet kan Danmarks digitale ry som foregangsland bruges til at skabe øget indflydelse, mens at Danmarks erhvervsmæssige styrke kan bruges hvad angår det ydre rum.

(2) Arbejde for international koordinering og regulering samt internationale normer - specielt igennem NATO og EU. Det er umuligt for en dansk regering 
at håndtere truslerne i cyberspace og det ydre rum alene. Derfor skal regeringen arbejde for en bredere international koordinering af udenrigs- og sikkerhedspolitikken i forhold til cyberspace og det ydre rum. Koordineringen kan styrkes ved yderligere informationsudveksling imellem udenrigs-, forsvars- og efterretningstjenester. Det vil forbedre efterretningerne og forståelsen for cyberspace og det ydre rum samt forbedre grundlaget for attribution af angreb.

En stor del af truslen på cyberområdet, men også i det ydre rum, skyldes manglen på normer, hvilket øger usikkerheden og frygten for eskalation. Samtidig risikerer Danmarks interesser at blive negligeret, hvis stormagterne ikke begrænses. Derfor bør Danmark også arbejde for at etablere fælles normer, der kan hjælpe til at binde stormagterne. Det gælder især normer for, hvad der er acceptable reaktioner på et cyber- eller rumangreb. Herudover bør Danmark arbejde for at etablere en fælles forståelse af, hvor sikker et land bør være i attributionen af et angreb, før det svares igen. Ligeledes bør der arbejdes for at etablere en norm imod missilangreb på satellitter for at mindske mængden af rumaffald.

Danmark bør ydermere arbejde for at integrere en stor del af cybersikkerheden $i$ internationale fora som NATO og EU, da det er tvivlsomt, om Danmark alene har kapaciteten til at forsvare sig imod eller afskrække angreb. Derfor bør Danmark arbejde for at gøre cybersikkerhed og sikkerhed i det ydre rum til et fælles anliggende. Fokus bør være at sikre afskrækkelse mod angreb på de vigtigste dele af infrastrukturen igennem NATO og EU, hvorefter Danmark selv kan styrke sit forsvar på mindre vigtige områder. Danmark bør også arbejde for at etab- lere fælles standarder for hardware- og softwaresikkerhed i EU for at mindske muligheden for cyberangreb. Ligeledes bør Danmark arbejde i EU for at regulere mængden af rumaffald. Det kan blandt andet ske ved at stille krav til opsendelsesprocessen og arbejde for løsninger i ESA.

(3) Prioritere forsvaret af danske interesser i cyberspace og det ydre rum.

Det er afgørende, at forsvaret af danske interesser i cyberspace og det ydre rum forstærkes. På cyberområdet indebærer det store investeringer i teknologi og infrastruktur samt øget fokus på at mindske menneskelige fejl. I det ydre rum indebærer det en offensiv diplomatisk indsats i EU og over for blandt andet USA.

Samtidig er det urealistisk helt at sikre det danske samfund mod cyberangreb. Derfor bliver enhver strategi nødt til at indeholde hårde prioriteringer. Danmark bør videreudvikle et lagdelt cyberforsvar, hvor de mest vitale dele af samfundet - infrastruktur som sundhedsvæsen og el- og vandforsyning - beskyttes mest. Det gælder både igennem afskrækkelse fra NATO og egne forsvarskapaciteter. Ydermere bør man med tanke på Ruslands påvirkningskampagner overveje også at prioritere kommunikation internt i de politiske partier, da det kan bruges til propaganda mod Danmark.

Om end alvorlige angreb mod danske interesser i det ydre rum er mindre sandsynlige end cyberangreb, er de stadig mulige. Her bør Danmark igennem EU og NATO arbejde for at skabe en klar afskrækkelse af angreb på de vigtigste satellitter. Det indebærer, at de vigtigste satellitter identificeres - fx GPS-teknologi og vital kommunikation - og at der opbygges en afskrækkelse af angreb på dem 
afhængig af deres vigtighed. Herefter kan Danmark i mindre fora lægge diplomatisk pres på enkelte lande for at beskytte de mindre betydningsfulde satellitter.

(4) Opmuntre en teknologisk kultur i befolkningen.

Cyberangreb rettes ofte mod individuelle personer og virksomheder, mens private virksomheder i stigende grad bliver en faktor i det ydre rum. Derfor bør Danmark skabe en teknologisk kultur i befolkningen for at mindske truslen mod det danske samfund samt for at øge Danmarks indflydelse i cyberspace og i det ydre rum.

Ved at skabe et internationalt forsk- nings- og innovationsmiljø i Danmark inden for cyber- og rumteknologi, kan vi øge innovation og viden relateret til cyberspace og det ydre rum. Af samme grund vil det være oplagt at skabe en række offentlig-private partnerskaber. Tilsammen kan det også lede til en større bevidsthed i den danske befolkning omkring sikkerhedsrisikoen i cyberspace og det ydre rum. Det kan ydermere komplementeres igennem informationskampagner, der sætter fokus på vigtigheden af den menneskelige faktor i specielt cybersikkerhed. 


\section{Er der et europæisk}

hukou-system i støbeskeen?

\section{Af Birgitte Egeskov Jensen}

Først lukkede vi delvist de indre grænser i EU, så blev Brexit en realitet - og i juni 2017 vedtog Folketinget den meget omtalte tiggerlov, der straffer nogle af EU's svageste borgere. For som Martin Henriksen udtalte til DR i den forbindelse, så er det ikke Danmarks pligt at afhjælpe de andre EU-landes sociale problemer.

Immigration har skabt så stort røre i EU gennem længere tid, at det nu er sidestillet med terror på EU's trussels-barometer. Det var ikke mindst det budskab, der fik næsten 52 pct. af briterne til at stemme for at forlade EU. Brexit har skabt et momentum for restriktioner på fri bevægelse samt medført en række menneskerettigheds-dilemmaer på tværs af EU. Men knapt som støvet efter Brexit har lagt sig, står det klart, at de i stigende omfang slørede linjer mellem interne og eksterne trusler ændrer måden, hvorpå folk tænker på national og personlig sikkerhed.

Et hukou-lignende system

Immigrationsdebatten, det stigende behov for at kontrollere den fri bevægelse og genoptagelsen af indre grænser i EU er en udvikling, der overraskende nok trækker tråde til det kinesiske husholdnings- registrerings-system, bedre kendt som hukou-systemet. Hukou-systemet er afgørende for individets adgang til sociale rettigheder såsom pension, uddannelse og sundhedsydelser. Ved at binde medborgernes sociale rettigheder til deres hjemstavn kontrollerer og regulerer regeringen intern migration i Kina gennem hukou-systemet.

Både EU og Kina er geografiske områder, der i stigende omfang har tilladt fri bevægelse af borgere inden for deres respektive grænser. De er dog også to vidt forskellige politiske enheder. EU er en overstatslig organisation, mens Kina er en nationalstat. Men i forhold til medborgerskab og borgernes tilhørsforhold deler de ét vigtig karakteristikum; et dobbelt medborgerskab. For EU-borgere gør dette sig gældende i skelnen mellem det overstatslige EU-medborgerskab og det nationale medborgerskab.

I Kina kan der på samme vis skelnes mellem det nationale kinesiske medborgerskab og det lokale hukou-medborgerskab. Dog er sociale ydelser i Kina stadig bundet til ens hukou, mens det overstatslige EU-medborgerskab sikrer, at sociale rettigheder til dels flytter med medborgeren gennem arbejdskraftens frie bevægelighed. 
Hukou systemet kan dateres tilbage til ‘Det Store Spring Fremad' i 1958-59, hvor alle borgere blev tildelt en hukou. Hukou'en blev oprindeligt brugt til at standardisere adgang til mad, landbrug, uddannelse osv. samt til at kontrollere befolkningsmobiliteten fra landet til byerne.

Hukou-systemet kræver, at borgerne skal registreres på en permanent bopælsadresse, som er afgørende for deres adgang til social velfærd. Migration har siden 1980'erne været muligt, og de økonomiske reformer har skabt stor efterspørgsel efter billig arbejdskraft, hvilket har drevet mere end 280 millioner migrantarbejdere fra landet til byerne.

Problemet er imidlertid, at de principielt ikke har adgang til sociale rettigheder inden for det urbane velfærdssystem, da deres hukou er registreret i deres hjemstavn. Dette gør, at migrantarbejdere, også kendt som 'den flydende befolkning', ofte må arbejde i nattens mulm og mørke med at producere, bygge og levere produkter under usikre og kummerlige forhold.

Ønsket om en reform af Kinas hukou-system har vundet frem $i$ de senere år og fået høj-prioritet blandt kinesiske politikere, der i 2015 erklærede, at 100 mio. urbane hukou'er ville blive bevilliget til urbane beboere med en rural hukou inden 2020 .

EU, FN, internationale medier og menneskerettighedsforkæmpere har gentagne gange rost denne reformvilje fra den kinesiske regerings side. Men på samme tid som vi ser en lempelse af de hypotetiske indre grænser i Kina, bliver EU ironisk nok i højere grad splittet i en kerne og en periferi; og ligesom i det kinesiske hukou-system bærer denne opdeling en skarp konnotation af kernen som 'de rige og overlegne' og periferien som 'de fattige og underlegne' med sig.

Det ofte udskældte hukou-system af- skærer en stor gruppe af befolkningen fra at opsøge højkvalitetsuddannelse og -sundhedspleje for ikke at nævne sociale tjenesteydelser og goder i byerne ved at begrænse mulighederne for migration og effektivt stemple dem som andenrangs borgere. Migration til de største byer i Kina anses stadig som værende yderst betinget, og migrant-børn udelukkes endda fra det urbane skolesystem.

\section{Rettigheder og reformer}

Migration eller fri bevægelse har ofte været genstand for diskussion og kritik inden for EU - og emnet har især fået sin anden renæssance i tiden op til og efter Brexit.

Selve ideen om den frie bevægelighed for arbejdskraft inden for EU blev undfanget $i$ en tid, hvor der var en større grad af homogenitet blandt EU-landene. Efter man har løftet kontrollen med de østeuropæiske lande, har der været en grad af bevægelighed, som de færreste havde kunnet forestille sig. Ligesom med migration fra rurale til urbane områder i Kina var der i EU en frygt for, at østeuropæere ville strømme over grænserne til Vesteuropa i jagten på et bedre liv.

Den største frygt bag østudvidelsen var forbundet med fænomenet 'velfærdsturisme', der er et begreb, som har været benyttet i den politiske debat om EU siden 1990 'erne. Begrebet havde sin storhedstid i tiden op til og efter EU's østudvidelse i 2004. Det var funderet i en frygt for, at de nye EU-borgere ville flytte til de eksisterende medlemsstater for at drage fordel af deres sociale velfærdsydelser snarere end for at opsøge arbejde.

Som EU-borger har man som udgangspunkt kun ret til at modtage sociale ydelser i andre EU-lande, hvis man får status som arbejdstager. Tilknytning til arbejdsmarkedet er derfor en forudsætning for, 
at EU-borgere, der kommer til Danmark, kan nyde godt af de danske velfærdsgoder. Velfærdsturisme kan derfor anses som værende en teoretisk udfordring snarere end en praktisk udfordring.

Men som begrebet velfærdsturisme efterhånden har mistet sin gennemslagskraft, er et nyt EU-problem opstået; de EU-borgere, som er kommet til Danmark, men ikke har kunnet finde arbejde og derfor ikke er berettiget til velfærdsydelser.

I Danmark er denne udvikling især kommet til udtryk efter en tiltagende debat om udenlandske 'utryghedsskabende' hjemløse i gadebilledet i forsommeren 2017. Denne debat resulterede i den omtalte tiggerlov, der yderst effektivt gør hjemløse til kriminelle for at tigge på gaden. Og senest har regeringen lagt op til, at det såkaldte zoneforbud skal udvides, således at hjemløse, der bliver taget $i$ at sove i 'utryghedsskabende' lejre, kan få et zoneforbud, der omfatter hele kommunen.

Ud over zoneforbuddet arbejder regeringen samtidig for, at udlændinge, som forbryder sig på reglerne, udvises fra landet hurtigst muligt, hvis der findes grundlag herfor. Københavns overborgmester Frank Jensen omtalte tidligere på året $\mathrm{i}$ Politiken problemet som et EU-relateret problem, 'da mange af migranterne er her lovligt som EU-borgere'.

Udviklingen er også evident $\mathrm{i}$ andre rige EU-lande; Tyskland, Holland med videre har vundet flere sager ved den Europæiske Unions Domstol, som har fastslàet, at folk fra de fattigere østeuropæiske lande ikke er berettiget til omgående at modtage velfærdsydelser i rigere EU-lande. Indtil videre er det dog kun Storbritannien, der har meldt ud, at man ønsker at sætte en stopper for den fri bevægelse af arbejdskraft.

Men konceptet, eller idealet, bag fri be- vægelse af arbejdskraft er i flere henseender blevet eroderet på tværs af EU, først og fremmest i forhold til begrænsningerne af velfærdsydelser - og er på mange måder blevet et udtryk for den 'variable geometri', der plager integrationen i EU.

\section{Samme problematik i Beijing}

I Beijing ser vi i denne tid den samme problematik, dog i en noget anden grad. Myndighederne har i december 2017 iværksat en 40-dages oprydningskampagne, angiveligt for at rydde byen for usikre og potentielt farlige bygninger under henvisning til en dødbringende brand i november i en af Beijings utallige barakbyer.

Umiddelbart kunne dette tiltag virke som et forsøg på at bekæmpe de kummerlige forhold, som en stor del af byens beboere lever under. Kampagnen, der har til formål at rydde 40 mio. kvadratmeter af illegal bebyggelse, vil dog have store konsekvenser for en stor del af Beijings mere end otte millioner permanente migrantarbejdere og tvinge dem på gaden, uden tag over hovedet til vinter. Migrantarbejderne er, meget ligesom de hjemløse EU-borgere i Danmark, blandt de svageste i samfundet og på grund af deres status som 'perifere' borgere frataget muligheder og rettigheder.

Man kan selvfølgelig ikke sidestille brutaliteten bag kampagnen i Beijing med tiggerloven eller zoneforbuddet, men budskabet bag er det samme: I hører ikke til her. Om man kommer fra det rurale Kina eller den europæiske periferi, så er man ikke velkommen ved de riges bord. Dog kan man inden for EU nyde, hvis man vil yde.

Det paradoksale er, at man har brug for den rurale arbejdskraft i de kinesiske storbyer, ligesom at vi i den europæiske kerne har brug for arbejdskraft fra resten af EU. En vigtig forskel er dog, at tiggerloven og 
zoneforbuddet ikke er rettet mod de arbejdende men snarere mod dem, der ikke arbejder.

I Kina har regeringen en interesse $i$ at fastholde en del af arbejdskraften i rurale områder, dels for at fremme den rurale udvikling, dels for at undgå masseflugt fra rurale til urbane områder, hvilket kunne medføre belastende urbanisering og ghettodannelse.

Inden for EU er det nogle mere fragmenterede interesser, der kommer i spil - og i højere grad bundet op på nationale frem for overnationale interesser. Dette ændrer dog ikke ved, at vi i Danmark har behov for udenlandsk arbejdskraft for at opretholde den danske vækst. Ifølge Vismandsrapporten fra efteråret 2017 kan tilgangen af udenlandsk arbejdskraft være med til at holde den danske vækst på omkring to pct. om året i gennemsnit fra 2019 til 2025.

Ydermere viste en rapport fra Dansk Arbejdsgiverforening fra november 2015, at østeuropæere havde et nettobidrag til offentlige finanser på mere end $15.000 \mathrm{kr}$. per person i 2012/2013. Dermed kan man argumentere for, at østeuropæere snarere har været velfærdsgivere end -tagere.

Det kan heller ikke antages, at afsenderlande inden for EU nødvendigvis er positivt indstillede over for denne udstrømning af arbejdskraft; en flugt af kvalificerede arbejdere er ikke nødvendigvis i deres bedste interesse.

For eksempel tog den polske ambassadør i Danmark, Henryka Mościcka-Dendys, for nylig på charmeoffensiv hos en række danske virksomheder for at forsøge at lokke polske arbejdere hjem igen. Den polske økonomi er blevet bedre, og der er nu mangel på arbejdskraft inden for flere sektorer i Polen. Det er derfor blevet en politisk prioritet for den polske regering at trække en del af de 2,4 mio. polakker hjem, som tog til Vesten efter EU's østudvidelse i 2004.

\section{Hvad byder fremtiden på?}

Med den nylige hvidbog fra marts 2017 om Europas fremtid og vejen frem har Europa-Kommissionen lagt fundamentet for en forenet Europæisk Union. Hvidbogen fremsætter op til flere scenarier for videreudviklingen af EU i kølvandet på Brexit, hvilket for tiden deler vandene mellem EU's medlemslande.

Der er en unik mulighed for at genoplive og/eller genopfinde det kontinentale sociale projekt efter Brexit; ved at udvide europæisk integration til at inkorporere positiv frihed, forstået som muligheden for og evnen til at udfylde ens potentiale gennem fri mobilitet, baseret på en fælles social kontrakt. Der er dog en substantiel risiko for, at Brexit har skabt eller vil skabe en spill-over effekt, hvor thatcherisme via EU-skepsis og en blind tro i negativ frihed vil resultere $i$ et mindre integreret $\mathrm{EU}$.

Det er kritisk for EU's fremtid at beslutte, om vi kollektivt skal fokusere på ambitiøs social udvikling med social sikkerhed og lighed eller optere for kortvarige resultater - kernen i den britiske EU modstand.

Den vidtrækkende institutionelle diversitet af social sikkerhed er grobund for protektionisme og signalerer et ønske om at ekskludere fremmede fra at forlange lokale sociale velfærdsgoder. Logikken bag denne 'fremmedgørelse', skaber en form for nationalt medborgerskab, hvor social beskyttelse og socialt medborgerskab er yderst opdelt stik mod EU's intentioner om at beskytte den fri bevægelse men meget lig logikken bag det kinesiske hukousystem.

Situationen skaber nærmest en form 
for hukou-system inden for EU's grænser, hvor nationalstater beskytter nationale borgere og gransker EU's regulativer for at regulere sociale rettigheder for EU-borgere, der kommer fra den europæiske periferi. I mange tilfælde er årsagen ganske nobel; nationer ønsker at undgå at underminere det nationale velfærdssystem.

Til en vis grad er dette også blevet grundlaget for det kinesiske hukou-system, som vi kender det i dag.

EU's medlemslande har ikke mulighed for selv at kontrollere bevægelsen på tværs af deres grænser, og grundet manglen på et fælles socialt projekt er der store forskelle i rentabiliteten ved at migrere til forskellige medlemsstater. Derudover er den frie bevægelse ikke homogen på tværs af medlemslandene; der er store forskelle på, hvilke medlemslande der leverer og modtager, hvilket ofte er determineret af den socioøkonomiske tilstand i landet.

\section{Rammen om trusselsbilledet}

I den senere tid har der været en tendens til at skabe en 'os versus dem'-dikotomi mellem den europæiske kerne og periferi i de europæiske medier og blandt politiske eliter. Der eksisterer en frygt for at 'de', der kommer fra udkants-EU, vil øge efterspørgslen efter fx uddannelse og sygehusvæsen i de rige medlemslande, og at dette vil skabe et betydeligt pres på velfærdsstaterne samt udfordre den lokale eller nationale kultur.

Dernæst er der en frygt for, at 'de' er mindre uddannede og kultiverede - og dermed ikke vil kunne klare sig på arbejdsmarkedet og vil ende med at dræne velfærdssystemet. Den fri bevægelighed i EU gør det uden tvivl nemmere for EU-borgere at få indkomstoverførsler i de andre EU-lande, men adgangen er bundet op på, at man kommer for at arbejde.
Frygten eller truslen har dog manifesteret sig omend på en noget anden vis i flere europæiske storbyer, hvor den lokale befolkning føler sig truet af de såkaldte romaer, der ikke formår at integrere sig på arbejdsmarkedet, ikke er berettiget til sociale ydelser og er tvunget til at kriminalisere sig for at overleve.

Ligesom man ikke kan misunde de kinesiske politiske beslutningstagere den opgave, de står overfor, så kan man heller ikke misunde deres danske og europæiske pendanter. Selvom det er nemt at drage forhastede konklusioner omkring deres tilgang, så er situationen yderst kompleks og nuanceret.

Brexit var til dels en reaktion på flygtningekrisen, men det var også et udtryk for et ønske om et større fokus på national sikkerhed inden for EU i en tid, hvor EU som helhed ikke magtede den sikkerhedspolitiske opgave, vi stod overfor. Nationale interesser vandt over de overstatslige EU-interesser; og EU gik fra at være et fællesprojekt til at være 'alle lande for sig selv', efterhånden som flere lande lukkede deres ellers åbne grænser som en reaktion på det i stigende omfang slørede trusselsbillede. Men det er værd at overveje, om ikke den reelle trussel er at returnere til et EU med grænser og barrierer.

Fri bevægelse har visse udfordringer, men de glæder, som vi opnår ved fri bevægelighed, er kort sagt for gode til at sætte over styr og returnere til et EU med grænser.

I stedet for at lade sig inspirere af det gamle hukou-system kunne danske og europæiske beslutningstagere tage ved lære af de kinesiske ledere og arbejde for et EU med fokus på rummelighed, åbenhed og lige rettigheder. 


\section{Merkels sidste sejr}

\section{Af Lykke Friis}

Hvorfor overhovedet beskæftige sig med det tyske valg? Angela Merkel vinder da under alle omstændigheder. Det var kammertonen efter sommerferien i mange europæiske hovedstæder og i Tyskland, hvor valgkampen hurtigt blev karakteriseret som en sovevognsvalgkamp. I de sidste uger op til valgdagen den 24 . september steg intensiteten imidlertid. Ikke mindst i det tidligere Østtyskland blev kansleren modtaget til valgmøder med 'Merkel muss weg-bannere', skingre dommerfløjter og røde kort. Lykke Friis ser tilbage på efterårets kanslervalg, der ændrede Tyskland.

Da valgresultatet tikkede ind, stod det klart, at Merkels konservative parti som ventet var blevet langt det største parti. Men ikke desto mindre var valget en sviende lussing til det etablerede Tyskland. De to regeringspartier CDU/CSU og SPD gik til sammen tilbage med 13,7 pct. og samlede nu kun 53,4 pct. af tyskerne. For første gang siden 1950'erne kom 7 partier (CDU, CSU, FDP, AfD, SPD, De Grønne og Die Linke) ind i Forbundsdagen. Størst opmærksomhed samlede sig om det nye højreorienterede parti, Alternative für Deutschland (AfD), der fik 12,6 pct. af stemmerne.
Trods svækkelsen af kansleren og det etablerede Tyskland regnede de fleste i ind- og udland med, at det ville lykkes Merkel at samle en såkaldt Jamaica-koalition bestående af CDU/CSU, FDP og De Grønne. SPD havde nemlig på valgnatten gjort det klart, at partiet ikke stod til rådighed for en ny stor koalition. Ikke alene var Merkel som pragmatiker uden de klare ideologiske synspunkter som skabt til moderator-rollen. Hun havde også forhandlingserfaringen efter utallige natteforhandlinger i Bruxelles, Moskva og Ankara.

Efter to måneders sonderingsforhandlinger udvandrede FDP's nye formand Christian Lindner imidlertid pludselig fra forhandlingerne, da han ikke kunne få øje på det fælles regeringsprojekt. Chokket $\mathrm{i}$ ind- og udland var betydeligt. Hvor var den stabile sovevogn dog blevet af, og hvem skulle nu overtage rollen som 'den frie verdens leder' efter Trump og Brexit?

Eller som Süddeutsche Zeitungs europaekspert Stefan Kornelius skrev lige efter sammenbruddet: "Det positive billede af Tyskland er så fast etableret, at ustabilitet ikke indgår i de allieredes og naboernes kalkule. På et tidspunkt, hvor den vestlige verden lider af et massivt ledelsesproblem, udløser krisen i Tyskland et chok... 


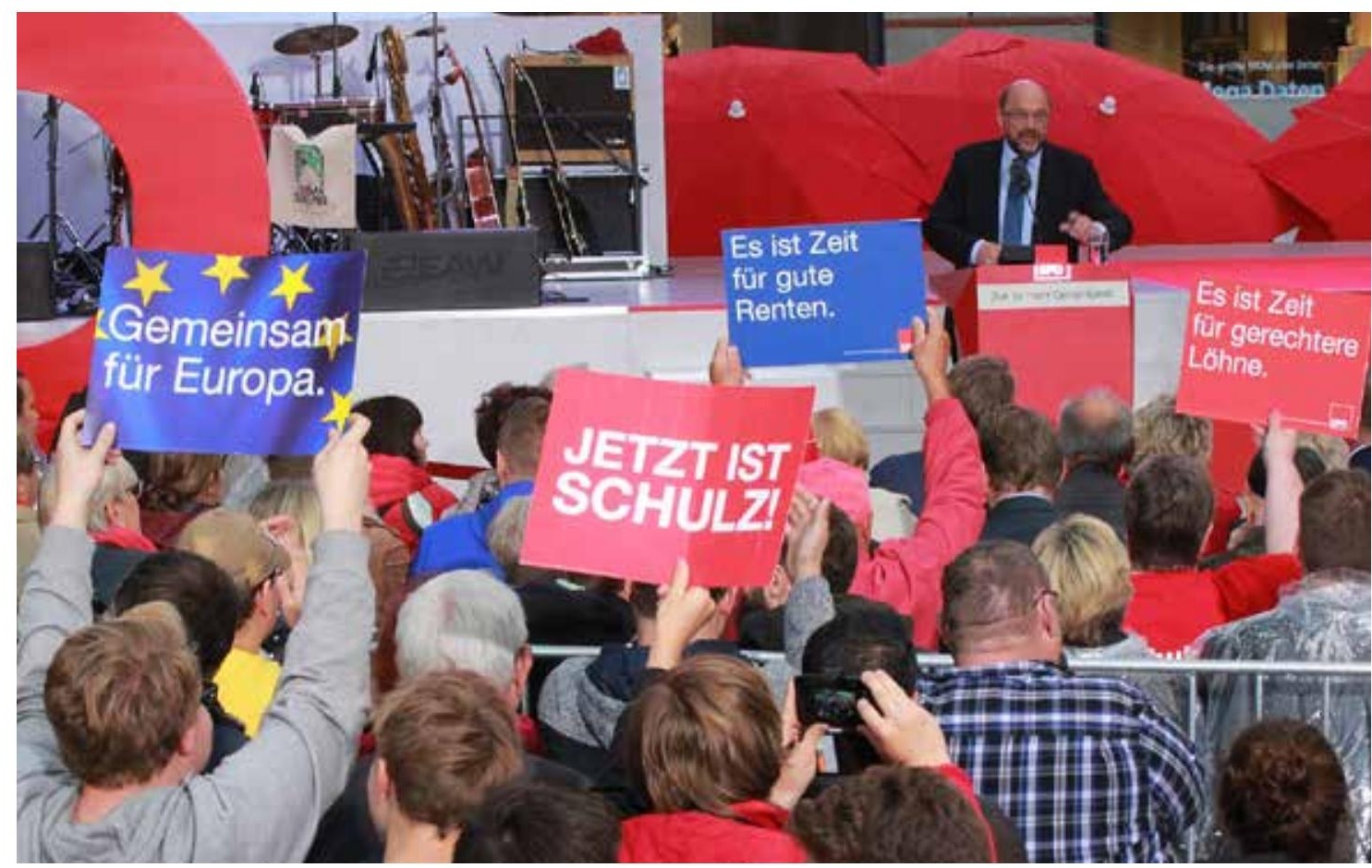

FOTO: Christallkeks via wikimedia commons

SPD-vælgermøde den 6. september 2017 i Münster

Krisen i Berlin er en krise for kontinentet. Hvis man tager uforudsigeligheden af Trump-Amerika med, bliver det til en krise for Vesten".

\section{Merkels mareridtssejr}

"Vi har opnået vores mål. CDU er det største parti, og vi beholder kanslerposten, da ingen kan danne regering uden om os". Trods et overraskende dårligt valg, hvor Merkels parti gik tilbage fra 41,5 pct. i 2013 til 32,9 pct., var der ingen gravkammerstemning at spore hos kansleren på valgnatten. Dagen efter erklærede hun, at hun ikke kunne se, hvad hun kunne have gjort anderledes i valgkampen, og at det efter 12 år ved magten $i$ en krisetid (finans-, euro- og flygtningekrise) var alt andet end en selvfølge, at magten blev på konservative hænder.

Tysklands største tabloidavis Bild var derimod hurtig til at karakterisere Merkels valgresultat som en 'mareridtssejr.' Hvordan kunne Merkel tabe så mange stemmer? Og hvordan kunne Bayerns ministerpræsident Horst Seehofer fra CDU's søsterparti, CSU, gå hele 10 procentpoint tilbage i Bayern - oven i købet året før, der skal være delstatsvalg i den 12 mio. store delstat?

Uanset at andre faktorer også spillede ind, skal hovedforklaringen søges i Merkels håndtering af flygtningekrisen. Beslutningen om ikke at lukke de tyske grænser til Østrig i september 2015, men tillade at over en mio. flygtninge og migranter fra bl.a. Syrien kunne komme til 


\section{Eller som Süddeutsche Zeitungs europaekspert Stefan Kornelius skrev lige efter sammenbruddet: “Det positive billede af Tyskland er så fast etableret, at ustabilitet ikke indgår i de allieredes og naboernes kalkule.}

Tyskland, ændrede mange tyskeres syn på kansleren.

Pludselig blev hun ikke set som den sikre, stabile politiker, der altid analyserer situationen igennem én gang til, inden hun træffer en beslutning. Nu var hun pludselig en politiker, der agerede på baggrund af følelser, og som handlede alt for sent, da det stod klart, at strømmen mod Tyskland ikke ville aftage.

Hvor AfD før flygtningekrisen levede en henslumrende tilværelse under spærregrænsen, betød Merkels håndtering, at partiet for alvor fik vind i sejlene. På valgdagen satte en mio. tidligere CDU'er deres kryds ved AfD, og partiet måtte lide den tort, at der for første gang siden 1950'erne blev plads til et parti til højre for CDU/CSU.

\section{Willkommenskultur?}

Valgkampen var præget af, at Merkel fastholdt, at hun havde handlet rigtigt i 2015 ('vi kunne jo ikke bruge vandkanoner ved grænsen'), men at situationen ikke måtte gentage sig. At den store koalition for længst havde erstattet den oprindelige humanitære 'Willkommenskultur-kurs' med markante stramninger (grænsekontrol, udsættelse af familiesammenføringer etc.) blev imidlertid ikke trukket frem som tegn på, at kansleren havde lyttet til bekymringerne. Dette fik den nu tidligere formand for Forbundsdagen, Norbert Lammert (CDU) til efter valget at bemærke, at han ikke helt forstod, "hvorfor man korrigerer sin politik, efter man har erkendt sine fejl, men kommunikativt fors $\varnothing$ ger at efterlade indtrykket af, at man ikke har ændret noget".

En mulig forklaring er, at Merkel ved sin oprindelige flygtningekurs ganske vist tabte mange af sine egne, men til gengæld vandt mange nye vælgere fra centrum-venstre. Ikke mindst unge vælgere, der traditionelt har været stærkt skeptiske over for CDU/CSU bakkede op om kanslerens humanitære kurs. Hele 57 pct. af de 18-21 årige ønskede, at Merkel skulle fortsætte som kansler. På grund af Tysklands aldrende befolkning er støtten hos de unge blevet en bitter nødvendighed for CDU. Ganske tankevækkende tabte Merkel i den forgange valgperiode flere vælgere til kirkegården end til AfD!

Selvom kanslerens manglende understregning af, at 'Willkommenskulturens' dage var talte, givetvis gav vælgermæssig pote hos nye vælgere, skabte den også forvirring om CDU's egentlige kurs. Eller som et genvalgt CDU-forbundsdagsmedlem sagde til mig nogle uger efter valget: "Det blev simpelthen for taktisk. Og det var lidt svært at berolige potentielle AfD-vælgere om, at vi for længst havde skiftet kurs, når kansleren sagde, at hun ville gøre det samme i dag som i 2015”.

Det hjalp bestemt heller ikke på situationen, at CDU og CSU reelt ikke havde fået løst deres indbyrdes uenighed om flygtningekrisen før valget. Fx fastholdt Seehofer, at Tyskland skulle indføre en øvre grænse ('Obergrenze') for flygtninge, samtidigt med at han forvirrede nogle af sine vælgere ved først at være Merkels største kritiker på flygtningeområdet for så op til valget at erklære, at han havde 100 pct. tillid til hende. Ganske interessant endte $\mathrm{AfD}$ med $\mathrm{i}$ Bayern at få det bedste valg i det gamle Vesttyskland med 12,4 pct. af stemmerne. 
Ud over almindelig slitage efter 12 år ved magten skal de øvrige forklaringer på CDU/CSU's tilbagegang søges $i$, at mange konservative vælgere var utilfredse med, at Merkel over årene har rykket partiet mod midten. Det gælder fx på energiområdet med afskaffelse af atomkraft, på familieområdet med accept af homovielser og på arbejdsmarkedsområdet med indførelsen af mindstelønnen.

Endelig kommer man ikke udenom, at valgkampen også spillede en selvstændig rolle. Merkels valgkamp var i høj grad lagt an på, at hun skulle slå SPD's kanslerkandidat Martin Schulz. Men efter valgkampens eneste tv-duel mellem de to i starten af september stod det klart, at Schulz ikke havde en chance for at afløse Merkel i det tyske statsministerium. Dynamikken i valgkampen rykkede derfor fuldstændigt over på spørgsmålet om, hvilket parti der ville blive tredjestørst: De Grønne, Det liberale parti (FDP), Die Linke eller AfD?

Kampen om tredjepladsen kunne også give svaret på, hvem Merkel kom til at regere med. Fra at flygtningespørgsmålet indtil september ikke havde spillet den store rolle i valgkampen, rykkede det op på dagsordenen, ikke mindst på grund af det nye fokus på AfD. Ikke alene betød det, at der kom ny debat om CDU/ CSU's akilleshæl (flygtningepolitikken) et politikområde, hvor CDU's valgplakater - "Für ein Deutschland in dem wir gut und gerne leben" - i det tidligere Østtyskland nærmest fremstod som en provokation. Ofte var frustrationen over flygtningepolitikken nemlig udtryk for en bredere bekymring for, at politikerne i Berlin ('Die da oben') beskæftigede sig mere med flygtninge end med den økonomiske udvikling fx i Sachsen.

Mindst lige så afgørende var det, at mange konservative vælgere i slutspurten støttede FDP (og AfD) i kampen om tredjepladsen, da Merkel jo under alle omstændigheder ville blive kansler. FDP, der ved sidste valg var røget ud af Forbundsdagen, endte således med at trække 1,5 mio. stemmer fra CDU/CSU. Ganske tankevækkende lå Merkels parti i ugerne før valget til 36-38 pct. af stemmerne, men endte med kun at få 32,9 pct.

\section{Schulz' mareridt}

Hvor Merkel på valgnatten skulle håndtere en 'mareridtssejr', stod Martin Schulz over for et fuldtonet mareridt. Med 20,5 pct. af stemmerne havde han opnået det dårligste resultat for SPD i efterkrigstiden. Nedturen for Schulz personligt var mildest talt også til at få øje på. I marts 2017 var han blevet valgt med 100 pct. af stemmerne som ny SPD-formand, og i målingerne havde han så meget fart på, at han konsekvent blev omtalt som 'Schulz-toget'. I en enkelt måling lagde han faktisk Merkel bag sig.

Ud over at tyskerne generelt var trætte af 'GroKo' (Den store koalition mellem CDU og SPD), skyldtes nedturen primært to ting. For det første valgte Schulz et valgkampstema (social retfærdighed), der ikke afspejlede den grundlæggende stemning i befolkningen. Ifølge målinger er over 80 pct. af tyskerne nemlig glade for deres job, som de for øvrigt heller ikke frygter at miste. Derimod var mange tyskere bekymrede for, hvordan deres land ville udvikle sig i lyset af flygtningekrisen og den stigende terrortrussel - to emner, som Schulz mest af alt ignorerede.

SPD's udenrigsminister Sigmar Gabriel, der i marts overlod formandsposten og kanslerkandidaturet til Schulz, ramte derfor hovedet på sømmet, da han efter valget kritiserede sin afløser: "Sloganet 'mere retfærdighed' var meget problematisk for 
et parti, som har været i regering i 16 af de sidste 20 år, da spørgsmålet ligger lige for: Og hvad har I så egentlig brugt tiden på?" Ifølge Gabriel var sloganet også udtryk for et internt, bagudskuende opgør med tidligere SPD-kansler Schröders arbejdsmarkedspolitik, Agenda 2010, men det var ikke der, vælgerne var. "Vælgerne ser ikke tilbage, men ud i fremtiden. Vi kunne ikke besvare spørgsmålene om sikkerhed, digitalisering og deres splittelse i flygtningespørgsmålet med en optimistisk fremtidsvision".

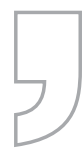

\section{Nedturen for Schulz per- sonligt var mildest talt også til at få øje på. I marts 2017 var han blevet valgt med 100 pct. af stemmerne som ny SPD-formand, og i målingerne havde han så meget fart på, at han kon- sekvent blev omtalt som 'Schulz-toget'}

For det andet fremstod der efter tv-duellen et så stort gab mellem Schulz' dårlige målinger og hans retorik ('jeg bliver kansler'), at det smittede af på hele hans troværdighed og partiets gennemslagskraft. I modsætning til i 2013 kunne han ikke på papiret samle et flertal sammen med De Grønne og Die Linke ('Rot-rot-grün'), ligesom han var så langt bagud i forhold til Merkel, at en ny GroKo med ham som kansler var ren science fiction.

At Schulz selv havde opgivet håbet, fremgik med al tydelighed, da nyhedsmagasinet Der Spiegel i oktober offentliggjorde en lang artikel af en journalist, der havde fået lov at følge Schulz som en flue på væggen under hele valgkampen. Lige efter tv-duellen sagde Schulz således følgende til journalisten: "Hver dag skal jeg sige, jeg bliver kansler, men alle ved: 'Han bliver da aldrig kansler'. Folk synes, jeg er pinlig. De griner da af mig".

\section{AfD tredjestørst}

Med SPD's katastrofevalg og CDU's bitre sejr var der reelt kun to steder, der var sejrstemning på valgnatten, nemlig hos FDP og AfD.

FDP, anført af Christian Lindner, gjorde comeback i Forbundsdagen med 10,7 pct. af stemmerne. Partiet var kritisk over for Merkels flygtningepolitik pga. 'kontroltabet ved de tyske grænser og svækkelsen af retsstaten', men lagde derudover stor vægt på Tysklands manglende digitalisering og innovationskraft.

AfD's store trækplaster var ikke overraskende flygtningekrisen og den stigende 'islamificering af Tyskland'. Partiets 12,6 pct. af stemmerne kom som et større chok for det tyske establishment (og i udlandet), da antagelsen var, at tysk historie havde vaccineret tyskerne mod nye succesrige højreorienterede partier i modsætning til fx Holland, Østrig og Danmark. 95 pct. af partiets vælgere gav udtryk for, at de var bange for at miste tysk sprog og kultur.

Reelt var det imidlertid kun 30 pct., der stemte på $\mathrm{AfD}$, fordi de var overbeviste om, at partiet udgjorde et indholdsmæssigt alternativ til de traditionelle partier. Hele 60 pct. satte derimod kryds ud for AfD, fordi de var skuffede over de traditionelle partier og ville give dem en lærestreg ('Denkzettel') for deres ageren i alt fra euro- til flygtningekrisen.

Med til partiets succes hører også, at det var langt bedre til at bruge de sociale medier end fx CDU og SPD. Partiet havde bl.a. hyret en tidligere Donald Trump-rådgiver, der skærpede partiets profil med en kampagne - 'Merkels blodspor igennem Europa' - der trak en di- 
rekte linje fra kanslerens flygtningepolitik til de mange terrorangreb i Europa. I det hele taget formåede partiet i slutspurten at tiltrække sig voldsomt meget opmærksomhed ved hjælp af provokationer. Et godt eksempel er spidskandidat Alexander Gaulands udsagn om, at tyskerne igen skal have lov til at være stolte over deres soldaters ageren under Første og Anden Verdenskrig.

Gauland og hans kolleger fik dog ikke lang tid til at hvile på laurbærrene. Allerede dagen efter valget meddelte partiets formand Frauke Petry på en højdramatisk pressekonference, at hun ville forlade partiet, hvorefter hun bogstaveligt talt udvandrede.

Siden er mange AfD'er på delstatsplan og et enkelt medlem af Forbundsdagen fulgt trop, og Petry er i færd med danne sit eget parti, Die Blauen. AfD's gennemslagskraft i Forbundsdagen og videre udvikling kommer derfor til at afhænge af, om den nye AfD-ledelse formår at holde sammen på partiet. Sporene skræmmer: På trods af at partiet kun har eksisteret siden 2013, har det allerede én gang før oplevet et stort formandsopgør, da stifteren Bernd Lucke i 2015 brød ud og dannede sit eget parti.

Under alle omstændigheder kommer partiet ikke til at få direkte parlamentarisk indflydelse, da alle partier allerede under valgkampen meddelte, at de ikke vil samarbejde med AfD.

På trods af at AfD oprindeligt blev skabt på en EU-kritisk platform, var diskussionen om EU-politikken nærmest ikke-eksisterende i valgkampen. Heller ikke Schulz brugte, trods sin fortid som formand for Europa-Parlamentet, synderligt meget tid på emnet. Åbenbart fordi hans rådgivere mente, at han havde brug for en langt bredere profil.
Reelt var der derfor kun tre udenrigspolitiske temaer, der spillede en - om end beskeden - rolle. Det ene var Tysklands forhold til Rusland, ikke mindst fordi det under valgkampen blev klart, at Gerhard Schröder stod til en ny formandspost i den statsejede russiske energisektor (Rosneft). Det andet var Tyrkiet, hvor Schulz plæderede for, at optagelsesforhandlingerne til EU skulle afbrydes, da landet ikke lever op til de såkaldte Københavner-kriterier. Som et eksempel på, hvor svært det var for Schulz at udfordre kansleren, meddelte hun hurtigt, at hun ville tage temaet op med kollegerne i EU.

\section{$\square$ Historikeren Timothy Garton Ash var ikke sen til at bemærke, at det i sig selv er udtryk for, hvor grundlæggende landet har forandret sig siden 1945, at 'vi i disse dage forventer mere af Tyskland end af os selv".}

Endelig forsøgte Schulz at fremstille NATOs beslutning om, at hvert land skal investere to pct. af BNP i forsvaret som et oprustningskapløb, der var blevet indledt af Donald Trump. Selvom emnet fyldte noget på Schulz' valgmøder, rokkede det ikke ved følgende overordnede paradoks, at hvor store dele af Europa og internationale medier i stigende grad ser mod Berlin for ledelse ('leader of the free world'), diskuterede tyskerne stort set ikke udenrigspolitik - eller om eller i hvilken retning de skal lede!

Uden tvivl var den store turbulens omkring Tyskland - i form af Brexit, Trump og Tyrkiets Erdogan - dog med til at styrke kanslerens kandidatur. 'Keine Experimente', som Konrad Adenauer gik til valg på i 1957, holdt også 60 år efter. 


\section{Tysk normalisering?}

"En fjerde periode er en personlig triumf for Merkel. Men hun har betalt en pris for sin flygtninge- og europolitik. Tyskland ligner nu i højere grad et 'normalt' vestligt land. Og ironisk nok er det ikke noget, der bør bydes velkomment".

Sådan skrev Financial Times' Gideon Rachmann i en analyse i dagene efter det tyske valg. Analysen afspejler en dobbelt bekymring. For det første har Tyskland nu også et højreorienteret parti i Parlamentet, og på grund af mange landes historiske erfaringer giver det naturligvis anledning til løftede øjenbryn, når et centralt medlem (Björn Höcke fra Thüringen) fx sætter spørgsmålstegn ved Holocaust-monumentet i Berlin.

Den anden bekymring knytter sig til Tysklands stabilitet. For hvor vanskeligt vil det være for Tyskland at regere med syv partier? Historikeren Timothy Garton Ash var ikke sen til at bemærke, at det i sig selv er udtryk for, hvor grundlæggende landet har forandret sig siden 1945, at 'vi i disse dage forventer mere af Tyskland end af os selv?.

Bekymringen for tysk ustabilitet blev blot yderligere skærpet, da Jamaica-sonderingerne brød sammen. For første gang i Forbundsrepublikkens historie var det således ikke lykkedes at danne en ny regering efter et valg, og pludselig blev to nyskabelser i moderne tysk politik diskuteret: nyvalg eller en mindretalsregering.

Ganske tankevækkende følte mange tyske kommentatorer sig foranlediget til at opdatere den gamle vesttyske besværgelse 'Bonn ist nicht Weimar.' Trods regeringskrisen er Tyskland ikke på vej tilbage til Weimarrepublikkens ustabilitet -'Berlin ist nicht Weimar. Ikke alene er forfatningen helt anderledes. Parlamentet kan ikke bare opløse sig selv. Alle politiske parti- er i Forbundsdagen bakker op om den demokratiske styreform, samtidigt med at Tyskland er præget af alt andet end massearbejdsløshed, hyperinflation og blodige kupforsøg.

Som et tegn på, at historien alligevel fortsat spiller en rolle, var dagene efter sammenbruddet karakteriseret ved, at forbundspræsident Steinmeier og Merkel kunne appellere til Socialdemokratiet om at revurdere deres nej til en ny stor koalition. I én og samme sætning fik Merkel afvist en mindretalsregering blot ved at referere til Weimar og ustabilitet, mens Steinmeier betonede alle partiers (læs SPD's) forpligtelse til at værne om stabiliteten. Desuden mindede han om Tysklands forpligtelser over for resten af Europa. Eller som den tidligere udenrigsminister Joschka Fischer udtrykte det: 'Tyskland er ikke Holland'.

På baggrund af dette pres accepterede et flertal på SPD's kongres i midten af december, at Schulz kan indlede sonderinger med Angela Merkel. Sonderingerne er 'ergebnisoffen', og inden Schulz kan deltage i forhandlinger om en ny 'GroKo', skal der afholdes en ny partikongres. En eventuel ny regeringsaftale skal godkendes af medlemmerne i en urafstemning, der minimum tager en måned at gennemføre. Hermed er der på forhånd lagt op til et langstrakt forløb, som kan give partiet tid til at vænne sig til tanken og erkende, at der reelt ikke er nogen let vej ud af krisen.

Meningsmålingerne peger p.t nemlig på, at SPD vil få et endnu dårligere valg, hvis der alligevel kommer nyvalg. Heroverfor står imidlertid, at mange socialdemokrater frygter, at partiet endnu engang vil gå under i en stor koalition med Merkel og dermed miste chancen for at indlede en egentlig fornyelsesproces. Historisk har det også vist sig, at hver gang de 
to store partier går sammen i Tyskland, styrker det fløjene i tysk politik. Reelt vakler socialdemokraterne således mellem bekymringen for ustabilitet (Weimar) og frygten for, at GroKo vil give yderligere medløb til Die Linke og AfD.

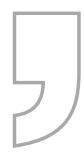

\section{Historisk har det også vist sig, at hver gang de to store partier går sammen i Tyskland, styrker det fløjene i tysk politik.}

Uanset hvordan regeringskrisen i sidste instans løses, er det et svækket Tyskland - og Merkel - der står tilbage. Ganske vist var ophøjelsen af Merkel til 'den frie verdens leder' fra starten af stærkt overdrevet, hvilket kansleren da også konsekvent gjorde opmærksom på. Ikke desto mindre havde kansleren udviklet en autoritet og et ry som 'Krisenmanagerin', der gjorde at mange i internationale forhandlingerne konsekvent så mod Tyskland.

Med det dårlige valg og Jamaica-sammenbruddet i baghovedet er noget af denne magi gået fløjten, samtidigt med at ingen forventer, at Merkel vil prøve at stille op igen i 2021. So oder oder vil Tyskland derfor skulle bruge energi på 'Merkeldämmerung': Hvem skal afløse kansleren som formand for CDU og som mulig ny leder af Europas stærkeste økonomi? Kort sagt: tyske politikere kommer uundgåeligt til at bruge mere tid på indenrigspolitik i de kommende år.

\section{Efterskrift}

I starten af februar 2018 lykkedes det Merkel og Schulz at afslutte regeringsforhandlingerne.

Schulz' beslutning om at ville træde ind i regeringen som udenrigsminister blev dog en kovending for meget for store dele af SPD's medlemmer. Dagen efter valget havde Schulz således både lovet, at SPD ikke ville indgå i en ny stor koalition, og at han aldrig ville påtage sig en regeringspost under Merkel Hårdt presset trak Schulz sig derfor som mulig udenrigsminister og også formand for SPD.

Merkel, derimod, blev kraftigt kritiseret af sine egne for at have afgivet finansministerposten til SPD. Som en konsekvens blev Merkel aftvunget et løfte om, at hun ville udpege 'flere nye ansigter' på CDU's regeringshold. Om regeringen er i stand til at tiltræde, afhænger imidlertid af, om det lykkes den designerede SPD-formand Andrea Nahles og den midlertidige formand Olaf Scholz at fà et ja i SPD-urafstemningen. Resultatet offentliggøres den 4. marts 2018. Hvis SPD's medlemmer siger nej, er det mest sandsynlige, at Tyskland skal til nyvalg - måske efter dannelsen af en overgangs-mindretalsregering.

Efter den markante kritik blandt konservative af forhandlingsresultatet er det et åbent spørgsmål, om Merkel vil kunne få opbakning til at være sit partis spidskandidat (15.2.2018). 


\section{Zimbabwe 2.0}

\section{Af Peter Tygesen}

Ti dage der rystede Afrika: I et forsøg på at sikre egne interesser og genvinde sin legitimitet fjernede Zimbabwes herskende elite i november Robert Mugabe ved et ublodigt paladskup. Under præsident Emmerson Mnangagwa kan regeringspartiet nyopsætte 1980'ernes forestilling om Zimbabwe som et afrikansk foregangsland.

Da hærens kampvogne omringede Mugabes hus natten til onsdag den 15 . november, havde det længe været klart for hans undersåtter, at Mugabes tid var ovre.

Den 93-årige præsident havde imidlertid hersket så længe og så brutalt insisterende, at to generationer ikke havde kendt andet. Hans styre forekom uden ende, og mens landet lukkede sig om sig selv og sin sociale og økonomiske katastrofe, forekom det hensunkent i den morbide apati, Antonio Gramsci beskrev som en følge af, at det gamle er døende, og det nye ikke kan fødes.

"Selv som lig vil han vinde det næste valg", skrydede hans kone, Grace, i februar 2017 og illustrerede, at styret med $\mathrm{Mu}-$ gabe i spidsen var som Berlinmuren: Absurd, forkvaklet og ødelæggende, men urørlig.
Siden en valgsejr i 2013 havde regeringen gældsat landet i stadig voldsommere omfang og samtidig fundet en fiks måde at trykke sine egne penge til at finansiere et dramatisk overforbrug. Da jeg besøgte landet i marts 2017, var den almindelige forventning blandt borgere og økonomer, at ZANU-PF styrede direkte mod en gentagelse af katastrofen i 2008, da Zimbabwe nåede verdens højeste hyperinflation på 500 mia. pct. Man var godt på vej: Fra januar til august 2017 voksede inflationen fra 0 til 50 pct. Men det var en lige så udbredt opfattelse, at man intet kunne gøre.

"Nu venter vi bare på, at Den Gamle dør", sagde en farmer til mig, "eller at økonomien bryder sammen". Der forekom på dette tidspunkt ikke andre mulige udgange af det jerngreb, hvormed oldingen lammede landets politiske system og dermed dets $ø$ konomiske og sociale liv. Oppositionen var splittet og svag, og ZANU-PF havde for længst demonstreret, at det besad tilstrækkelig med manipulativ kraft til at bestemme, hvem der skulle vinde valget.

Det eneste uafklarede spørgsmål syntes at være, om den ene eller den anden af disse udgange ville indfinde sig, før Mugabe vandt det kommende præsidentvalg $\mathrm{i}$ august 2018. 


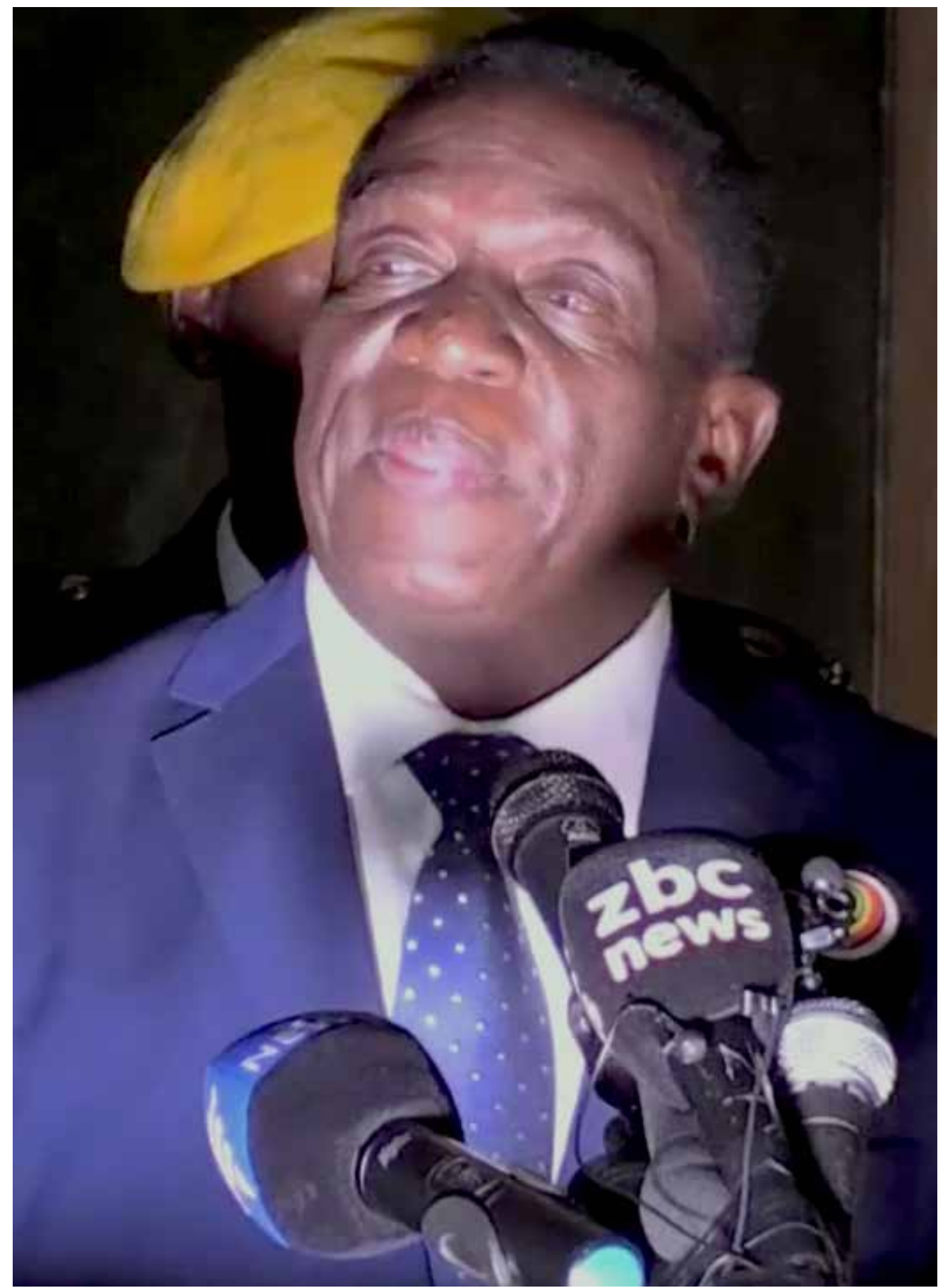

FOTO: Voice of America via wikimedia commons

Zimbabwes ny præsident Emmerson Mnangagwa i november 2017 
Så kunne han blive siddende til sit hundrede år.

\section{Brand og blod}

Kupplaner meddeles sjældent offentligheden på forhånd. Men det var netop, hvad Zimbabwes militære øverstbefalende, general Constantino Chiwenga, gjorde, da han mandag den 13 . november på en åben pressekonference sendte en klar advarsel til præsident Mugabe: "Vi bliver nødt til at minde dem, der står bag de seneste rævestreger i partiet, om, at militæret ikke vil tøve med at gribe ind, når det gælder beskyttelsen af vores revolution."

'Rævestreger' var et besynderligt ordvalg for de brutale udrensninger, der længe havde rystet regeringspartiet ZANU-PF, og som en uge tidligere fældede vicepræsident Emmerson Mnangagwa.

Partiets fløjkampe var orkestreret af $\mathrm{Mu}$ gabe selv, der i mange år mesterligt neutraliserede rivaler ved at spille dem ud mod hinanden. Han havde behændigt faet dem placeret $\mathrm{i}$ to lejre, den ene bag Mnangagwa, den anden bag Joice Mujuru, som blev anden vicepræsident i 2004.

Dette spil blev ændret dramatisk efter november 2009, da Wikileaks offentliggjorde et to år gammelt telegram fra den amerikanske ambassadør til udenrigsministeriet i Washington, hvor han beskrev et hemmeligt natligt møde med Joice Mujuru for at diskutere fjernelsen af Mugabe. Telegrammet med den dramatiske titel 'The End Is Nigh' hensatte Mugabe i paranoidisk raseri. Mujuru skulle elimineres.

Joice Mujuru var en letvægter, men det var hendes mand, Solomon, imidlertid langt fra. Som tidligere hærchef nød han stærk opbakning i hæren, og dét gjorde Joice nærmest urørlig. Ni måneder efter Wikileaks udbrød en mørk nat et inferno af en brand på Solomons farm. Brandbilen ankom uden vand. Solomon døde. Mugabe lod sig fotografere trøstende enken, mens de begge vidste, at hans næste træk ville være politisk dødeligt for hende.

Han kunne imidlertid ikke bare fjerne hende, for så ville Mnangagwa stå ene tilbage som hans arvtager. Det kunne skabe ubehagelige diskussioner om, hvornår han havde tænkt sig at gå af. Han havde for længst meddelte, at dén autoritet havde kun Gud.

For at opretholde den destruktive magtbalance mellem rivaler måtte Mugabe derfor introducere en ny kraft til neutralisering af Mnangagwa. Som redskab promoverede Mugabe en kreds af yngre, smiskende partimedlemmer, der alle var slikne efter at vippe den ældre generation af krigsveteraner af pinden. Mange var i 40-årsalderen, hvorfor gruppen blev kendt som 'G-40'.

Ingen af dem havde dog opbygget magtbaser tilstrækkeligt stærke til, at de kunne knuse Mugabes gamle fæller, og han forsynede derfor G- 40 med en brutal rambuk i form af sin yngre, ambitiøse kone, Grace. Hun var hidtil kun kendt for luksusshopping og ekspropriering af fede farme. Da hendes mand anbefalede partiet at gøre hende til leder af dets kvindeafdeling, havde det fået et tilbud, som ingen med omsorg for sit politiske eller fysiske liv kunne afslå.

Grace viste sig overmåde kapabel til både at smede rænker og beherske sprogets groveste finesser. Efter en brutal kampagne mod Joice Mujuru kulminerede hendes angreb i december 2013, da Mujuru blev fyret som vicepræsident og sammen med sine støtter udrenset af partiet, så hun, med Graces velvalgte ord, var efterladt så "ydmyget og nøgen, at ikke engang hunde vil nærme sig, fordi du stinker på trods af din parfume". 
Mugabe havde købt sig endnu nogle år på magtens tinde. I 2017 indledte han det endelige opgør med sin sidste rival. Igen var Grace rambukken: I flere offentlige taler ydmygede hun ikke bare Mnangagwa, men alle tilbageværende krigsveteraner med meddelelser om, at de ikke var noget særligt, bare fordi de havde deltaget $\mathrm{i}$ befrielsen af landet. Mugabe lod forstå, at hun skulle kåres som vicepræsident på partiets kongres i december. Som den nærmerede sig, blev først Mnangagwas støtter i partiet udrenset, og den 6. november blev han selv fyret.

\section{Revolutionens vogtere}

Resten kender vi: Bare en uge senere holdt general Chiwenga sin truende tale. Ti dage senere var Mugabe sat på historiens losseplads. Fredag den 24. november blev Mnangagwa indsat som landets nye præsident.

Begivenhederne gav genlyd over hele kontinentet. Jeg hørte nyheden på et hotel i det nordlige Uganda. Samme aften gik bølgerne højt i hotellets bar; et øldrevet skænderi blev oversat af venlige mennesker som en diskussion om, hvorvidt Ugandas hær tilsvarende kunne finde på at afsætte præsident Yoweri Museweni. Efter 31 år har han lige nu travlt med at ændre forfatningen, så han kan fortsætte. På trods af de hidsige indlæg var bargæsterne helt enige om, at nye kræfter burde træde til.

Sådan buldrede diskussioner overalt på kontinentet. Men hvor magtskiftets bølgevirkning i det øvrige Afrika kan afkodes forholdsvist let - det gav håb til de mange, der ønsker deres egne gamle hanelefanter sat på porten - er det imidlertid langt vanskeligere i Zimbabwe. Her konkurrerer mindst tre lag af parallelle fortolkningsverdener om forståelsen af perspek- tivet i Mnangagwas tiltræeden: Magtens, økonomiens og demokratiets.

Magtskiftets vigtigste resultat er foreløbig, at veteranerne i det væbnede nationalistparti ZANU-PF har konsolideret deres magt $\mathrm{i}$ håbet om at genvinde legitimitet med en ny frontfigur. To citater tjener til illustration af deres motiver. Chiwengas forgænger, general Vitalis Zvinivashi, sagde i 2002:

"Lad det være kendt at landets højeste embede er en spændetrøje, hvis bærer forventes at efterkomme frihedskampens mål. Vi vil derfor aldrig acceptere eller hverken støtte eller salutere nogen som helst med en anden dagsorden."

Det truende udsagn fra landets militære øverstbefalende var møntet på oppositionens leder, Morgan Tsvangirai, som en stor del af befolkningen på dette tidspunkt foretrak som 'bærer af landets højeste embede'.

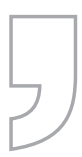
Magtskiftets vigtigste resultat er foreløbig, at veteranerne i det væbnede nationalistparti ZANU-PF har konsolideret deres magt $\mathrm{i}$ håbet om at genvinde legiti- mitet med en ny frontfigur.

Udtalelsen blev dengang fortolket som et umiskendeligt bevis for, at militæret ikke var, som krævet i forfatningen, politisk neutralt, men ene og alene ZANU-PF's væbnede gren. Den blev yderligere opfattet som en tilkendegivelse af, at militæret til enhver tid var parat til at gribe ind for at sikre partiet, styret af dets gamle garde af krigsveteraner, den fortsatte uantastede magt over landet. Derfor fik Tsvangirai aldrig lov til at vinde et valg. Det er almindelig kendt, at da han i 2008 var nærmest en sejr, sørgede hæren under 
Mnangagwas ledelse for en voldskampagne så brutal, at Tsvangirai opgav efter 400 af hans tilhængere var myrdet.

15 år efter Zvinivashis udtalelse ringede general Chiwengas meddelelse som et ekko. Nu kom truslen imidlertid ikke ude fra, men inde fra partiet: "de, som er bandsat på at kidnappe revolutionen, vil blive standset. ... Hvis drastisk handling ikke gennemføres øjeblikkeligt, er vort elskede Zimbabwe afgjort på vej til igen at blive en nykolonialistisk stat." Det var et arkaisk, besynderligt udsagn i 2017. 'Nykolonialistisk'? Hvem vil dog kolonisere Zimbabwe?

ZANU-PF's Zimbabwe har fra sin første dag haft to ansigter, to hoveder: På den ene side taler partiet revolution og lover et marxistisk, anti-imperialistisk opgør med det kapitalistiske Vestens dominans, herunder dets lokale hvide 'repræsentanter'. Retorikken danner basis for partiets påstand om social ansvarlighed som fundamentet for dets legitimitet. På den anden side følger partiet reelt en markedsøkonomisk praksis der, som tiden gik, blev stadig mere frådende rovdyrskapitalistisk.

Det tvehovede går igen i statsopbygningen. ZANU-PF fremviser et uhyre legalistisk system komplet med et tilsyneladende og ofte reelt velfungerende statsapparat, der peger i retning af en retsstat styret af konstitutionalisme og demokrati. Det har altid været magtpåliggende for ZANU-PF, at dets præsidentkandidat blev udpeget ved nationale valg velsignet af international godkendelse. Chiwenga indledte da også sin kup-advarsel med ordene: "Lad os begynde med at citere forfatningen...”.

På den anden side har partiet myrdet og fordrevet, fyret dommere og manipuleret domstole, stjålet og bedraget og i det hele taget tildelt sine ledere og tilhæn- gere straffrihed for de mest forfærdende forbrydelser, alt sammen i revolutionens navn, når det passede dem, der påberåbte sig dens opretholdelse.

\section{Økonomisk lys}

Der er en forventning i Zimbabwe om, at erfaringen fra Mugabetiden vil få ZANU-PF's nye ledelse til at føre en økonomiske politik, der leverer brød til folket som del i dens forsøg på at genvinde legitimitet.

Tro mod den tvehovede stat var Chiwengas omsorg derfor ikke alene ret-

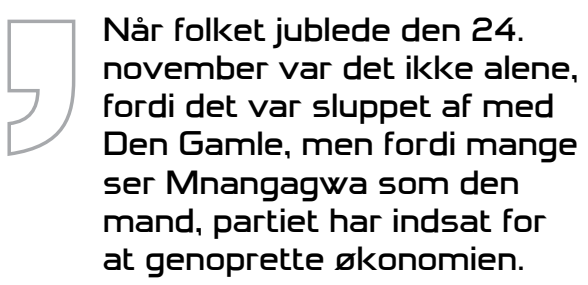

tet mod det revolutionære ansigt, men også mod det kapitalistiske. Hans analyse var præcis: "Som følge af kævleriet i ZANU-PF har der ikke været nogen udvikling af landet de seneste fem år. Den resulterende økonomiske stilstand har skabt udfordringer for den zimbabwiske befolkning som mangel på penge og stigende priser."

Når folket jublede den 24. november var det ikke alene, fordi det var sluppet af med Den Gamle, men fordi mange ser Mnangagwa som den mand, partiet har indsat for at genoprette økonomien. Han er 'erhvervsvenlig. De henviser blandt andet til det program for kommandolandbrug, han lancerede op til sidste landbrugssæson. Landmænd med adgang til kunstvanding kunne modtage gratis såsæd, kunstgødning og diesel mod til gengæld at sælge de første otte tons majs per hektar til 
det statslige opkøb (for en garanteret god pris). Resten kunne de frit sælge.

Programmet havde to overraskende sider: For det første var det lykkedes Mnangagwa at mobilisere pengene til programmet fra private investorer (tilknyttet partiet, ganske vist, og belønnet med generøse renter - men erhvervsvenligt!). For det andet tillod han diskret hvide landmænd adgang til programmet på jord, som de lejede af afrikanere. En ny klasse af effektive, hvide farmere er vokset frem, som ser fordele i tabet af ejendomsretten til jord, fordi de dermed er fritaget for investeringer i ejendomme og for forpligtelser over for de landarbejdere, der ellers skulle have løn uden for sæson samt huse, skoler, klinikker, etc.

Flere hundrede hvide farmere meldte sig til programmet sammen med, naturligvis, mange privilegerede storfarmere tilknyttet ZANU-PF. De hvides adgang til programmet var betinget af, at de holdt lav profil, for Mugabe var officielt imod. Han bøjede sig for nødvendigheden af, at landet producerede tilstrækkeligt mad frem til næste præsidentvalg. Op mod 40.000 småbønder blev også indrulleret i programmet, 'mest som vinduespynt' for præsidenten, forklarede en involveret leverandør af såsæd mig i marts 2017.

Hvorvidt programmet var en succes kan være vanskeligt at vurdere, for sjældent har Zimbabwe oplevet så perfekt en landbrugssæson som den netop afsluttede. Når lagrene bugnede af majs, skyldtes det så den rigelige regn eller kommandoprogrammet? Tilhængere hævder, at netop fordi sæsonen var så god, blev udbyttet af programmet tilsvarende ekstraordinært stort.

Allerede før han tiltrådte præsidentposten, havde Mnangagwa sikret og udvidet programmet i denne landbrugssæson. I sin tiltrædelsestale fokuserede
Mnangagwa netop på økonomien. Hans nye finansminister har lukket for pengestrømmen til de mange tabsgivende statslige virksomheder, der tidligere sugede af statskassen. Han har indsat den effektive luftmarskal Perence Shiri som landbrugsminister, angiveligt for at skabe orden i landets vigtigste økonomiske sektor og øge dens effektivitet. Siden fordrivelsen af de hvide farmere har landets matrikelsystem hængt i laser, og der foregår ingen konsekvent inddrivelse af jordskatter.

\section{Demokratisk underskud}

Mnangagwa lovede ved sin tiltræeden en 'effektiv og sikker stat'. Ikke en demokratisk. Ikke en retsstat. Men én, hvor korruptionen er mindsket, og hvor lønnen stiger.

Han har betalt for ZANU-PF's hamskifte ved at styrke militærets magt over staten. Det kan medføre styrket statslig kontrol med samfundet - på både godt og ondt. Øget respekt for loven og en effektiv jordreform vil være et gode. Men det begynder skidt: To generaler berygtede for brud på menneskerettigheder, en lang række nationale love og på folkeretten er nu ministre. Ovennævnte Shiri stod i begyndelsen af 1980'erne i spidsen for ZANU-PF's terrorkampagne mod minoritetsbefolkningen i landets sydvestlige regioner for at knuse dens opbakning til den rivaliserende befrielsesbevægelse ZAPU, hvor tusinder af civile blev myrdet og/eller tortureret. I skrivende stund (december 2017; red.) afholdes ZANU-PF's kongres med forlydender om, at Chiwenga skal kåres som vicepræsident.

"Vi har fjernet en tyran men ikke et tyranni!" tweetede menneskerettighedssagføreren og oppositionspolitikeren David Coltart den dag, folket jublede ved indsættelsen af Mnangagwa. 
Afrikas nye førerstater

Indsættelsen af Mnangagwa peger på, at ZANU-PF bevæger sig mod at skabe et land, der kan fremvise økonomisk fremgang, også for landets fattigste, men hvor et autoritært styre kan affeje enhver udfordring af dets magt. Forbilledet kunne være Kina eller Vietnam.

Som sådan vil det ligne Etiopien og Rwanda, der i vestlige medier fremhæves som de vigtigste eksempler på Afrikas økonomisk progressive lande. Begge er styret af stærkt autoritære regimer som lodrette dementier af, at demokrati skulle være en betingelse for økonomisk vækst i det fattige kontinent.

\section{Herhjemme argumentere- de Uffe Østergård i de- cember netop for, at 'vi er nødt til at slække på vores demokratiske ambitioner for Afrika'. lkke én modsagde ham offentligt.}

Zimbabwe vil kunne tage førertrøjen i denne liga af økonomisk effektive autoritære stater og dermed generobre den position, det havde i begyndelsen af 1980'erne som repræsentant for et fremadstormende Afrika.

Det råder over den vigtigste ressource for udvikling i Afrika: En veluddannet, entreprenant befolkning. Det har dygtige småbønder, erfarne storfarmere med adgang til international kapital og rester af den største industrisektor på kontinentet uden for Sydafrika. Det har jorden spækket med værdifulde mineraler som guld, platin og krom, men også diamanter og strategiske metaller. Det har kul og vand til energi - og lykkes det Mnangagwa at hele nogle af landets dybe, sociale sår, kan det hurtigt opnå en social sammenhængskraft og dynamik, som de to borgerkrigshærgede lande vil misunde. Udenlandske investorer, ifølge kilder i Zimbabwe også flere danske, har siden magtskiftet allerede vist interesse for at deltage i det forventede væksteventyr.

Om bare otte måneder står ZANU-PF under Mnangagwas ledelse over for en væsentlig prøve: For første gang i halvandet årti har det en reel mulighed for at vinde et ærligt valg. Kan partiet producere bare nogle få, mærkbare resultater, vil det kunne fastholde den nuværende bølge af medgang. Konfronteret med en svag, uorganiseret og fattig opposition, hvis dominerende parti er ledet af en kræftsvækket Tsvangirai, kunne det godt tage chancen med at opføre sig ordentligt.

Tør det - kan det overhovedet - bryde årtiers uvaner? Hvorfor skulle det? Stærke kræfter i både ind- og udland vil være tilfredse, hvis landet går økonomisk frem, og valget ser bare nogenlunde pænt $u d$. Overalt i Europa udgøres det nye sort i Afrika-politikken af muligheden for at egne virksomheder kan foretage givtige investeringer, ikke demokrati, god regeringsførelse eller respekt for menneskerettigheder. Herhjemme argumenterede Uffe Østergård i december netop for, at 'vi er nødt til at slække på vores demokratiske ambitioner for Afrika. Ikke én modsagde ham offentligt.

Vi får det første fingerpeg, når partiet skal beslutte, om det tør invitere valgobservatører fra USA, EU og Commonwealth, der de seneste årtier har været holdt ude. 


\section{Iran:}

\section{Hverken brød eller frihed}

Af Ali Alfoneh

Takket være sin beliggenhed midt i et af de mest seismisk aktive områder i verden rammes Iran bestandigt af jordskælv af forskellig styrke. Det samme gælder for tilbagevendende politiske skælv. Imidlertid har Den Islamiske Republik hidtil overlevet såvel geologiske som politiske rystelser. Det sidste kan lidt forenklet tilskrives de herskende eliters selvopholdelsesdrift kombineret med oppositionens spaltning i to indbyrdes stridende hovedgrupper: De som forlanger brød, og de som forlanger frihed. Nu hvor Den Islamiske Republik hverken ønsker eller evner at levere brød eller frihed, frygter regimet dagen, hvor de sultne og de frihedselskende gør fælles front.

Protestbølgen som skyllede over Iran i december 2017 var pjalteproletariatets oprør imod de iranske ledere.

Præsident Hassan Rouhanis bebudede budgetstramninger for finansåret marts 2018 til marts 2019, som indebar fjernelse af subsidier til benzinprisen (Iran er en af verdens største olieeksportører, men importerer benzin på grund af begrænset raffinaderi-kapacitet) samt hastigt stigende fødevarepriser og nogle regionale pensions- og sparekassers fallit starte- de fredelige protester i fattige forstæder til Mashhad i det nordøstlige Iran, men spredte sig hurtigt til det meste af Iran.

I begyndelsen rettede demonstranterne skytset mod Rouhanis økonomiske politik, men inden længe forvandlede protesterne sig til politiske optøjer med slagord mod Irans gejstlige magthavere, herunder Ayatollah Ali Khamenei og Revolutionsgarden, regimets betydeligste magtorgan.

En blanding af Rouhanis løfte om ikke at røre ved subsidierne, iransk politis forholdsvis professionelle tackling af protesterne samt Revolutionsgardens bemærkelsesværdige fravær på gadeniveau for ikke yderligere at provokere offentligheden bragte optøjerne til ophør i januar.

Regimet åndede lettet op: Middelklassen, som forlanger politiske rettigheder, sluttede sig ikke til de fattige, og protesterne bredte sig aldrig til Teheran eller Tabriz.

Skælvet hørte hjemme i den lavere ende af Richterskalaen og skrev sig på listen over fattigdomsoptøjer i Den Islamiske Republiks historie.

\section{Sociale optøjer}

I kølvandet på revolutionen i 1979, konsoliderede regimet sin magt ved effektivt at undertrykke al hjemlig opposition. Den revolutionære gejst samt den nationalisti- 


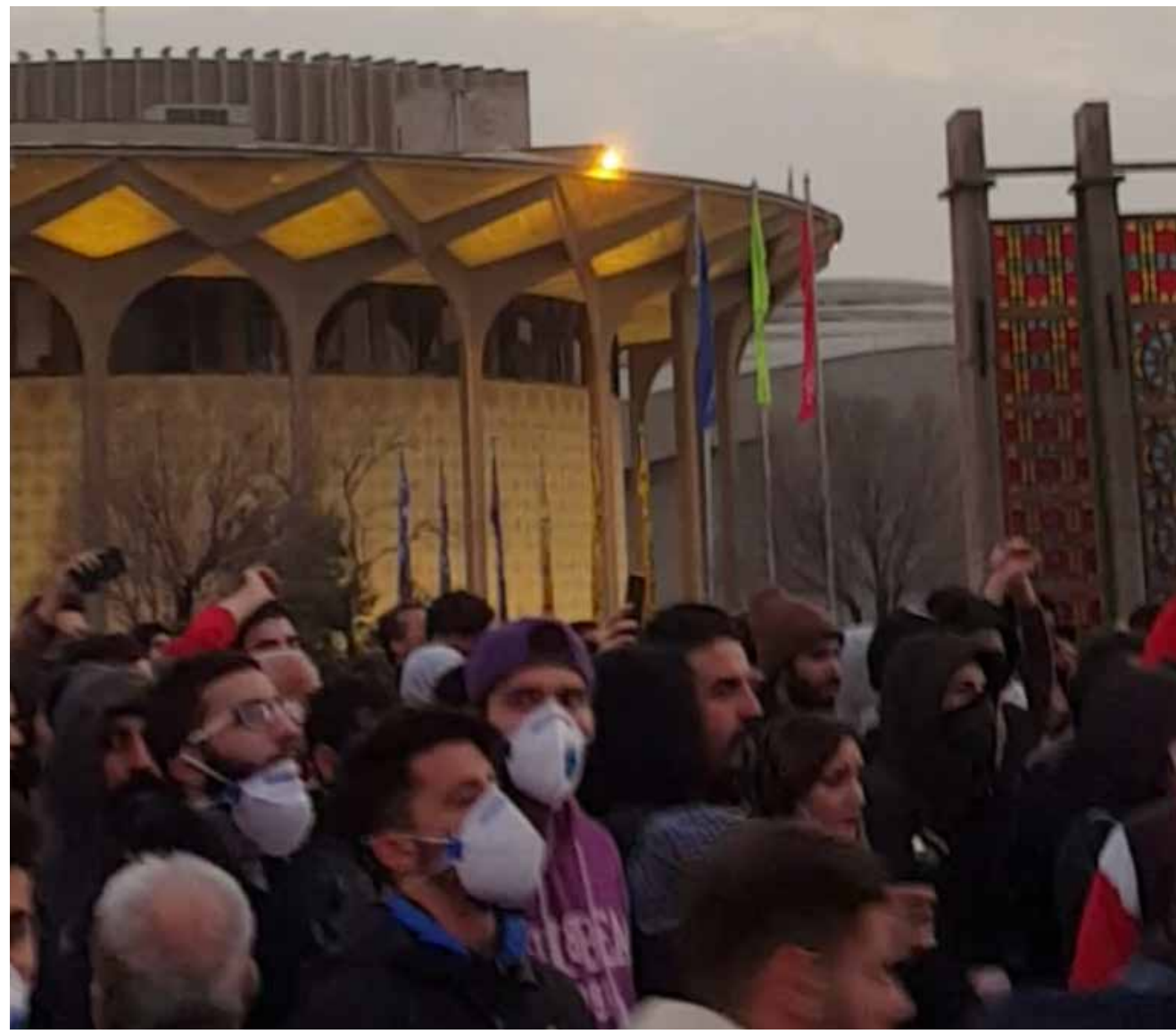

FOTO: GTVM92 via wikimedia commons

Iranere protesterer mod regeringen, Teheran 30. december 2017

ske vækkelse efter Iraks invasion af Iran i 1980 førte også til national samling. Med undtagelse af ganske få demonstrationer imod krigen hen mod krigsafslutningen i 1988 var der ingen større demonstrationer imod regimet.

Efter krigsafslutningen var stemningen en anden. Krigstidens selvopofrelse veg pladsen for stigende forventninger, og iranerne forlangte at få andel i fredsdividenden. Daværende præsident Akbar Hashemi Rafsanjani var dog mere optaget af at sikre Iran lån fra Verdensbanken. Washington Consensus var vigtigere end revolutionens løfte om social retfærdighed, og Rafsanjanis økonomiske reformer gik hårdt ud over fattige iranere, som længtes efter krigsårenes rationering af subsidierede basisfødevarer.

Optøjerne startede i maj 1992, hvor en tiårig dreng døde, da Mashhads bystyre forsøgte at jævne nogle blikskure i byens fattige forstæder med jorden. Hele nabolaget angreb den lokale politistation, afvæbnede politiet og brugte våbnene til at plyndre banker og sætte ild til offentlige bygninger i Mashhad.

Optøjerne spredte sig hurtigt til Arak i 
Markazi-provinsen, Mobarakeh i Isfahan og det fattige Chahardangeh-nabolag i det sydlige Teheran. Det var kun med nød og næppe, at Revolutionsgarden formåede at genoprette orden, og til skræk og advarsel hængte regimet anførerne i optøjerne på storbyernes centrale torve.

Sociale optøjer fortsatte i 1990'erne, og i april 1995 strejkede buschauffører i Teherans fattige Eslamshahr-forstad imod Rafsanjanis forsøg på at reducere benzinsubsidierne. Passagererne, som så deres busbilletter stige med 30 pct., sluttede sig til chaufførerne, og snart angreb 50,000 vrede syd-teheranere benzintanke og blokerede motorvejen til Teheran. Revolutionsgardens specialstyrker angreb oprørerne fra helikoptere, og 50 dræbte senere kunne regeringen genåbne motorvejene til hovedstaden.

\section{Politiske protestbølger}

Anderledes politiske var studenteroprøret i juli 1999. Den milde politiske atmosfære under præsident Mohammad Khatami havde givet iranske studerende mod på at gøre deres krav om yderligere politiske li-

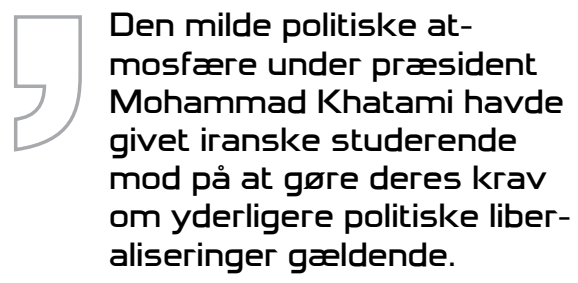

beraliseringer gældende.

Da censurmyndighederne lukkede det reformvenlige dagblad Salam, besatte de studerende Teherans Universitet og barrikaderede Meidan-e Enqelab (Revolutionstorvet). Besættelsen trak ud, men politiet fjernede de studerende, da en gruppe fremtrædende officerer fra Revolutionsgarden i et åbent brev til Khatami truede med at tage sagen i egen hånd for at 'forsvare revolutionen'

Den næste store politiske protestbølge opstod i juni 2009 fremprovokeret af præsidentvalget, som for anden gang - og mod forventning - kårede Mahmoud Ahmadinejad som republikkens præsident. Protesterne, som var en slags forløber for hvad der senere blev kendt som 'Det Arabiske Forår,' skabte Irans 'Grønne Bevægelse', som kulminerede i demonstrationer i Teheran, hvor en million iranere gik på gaden imod valgsvindel.

Bevægelsen var måske nok anført af de økonomisk bedrestillede borgere i Teheran og andre storbyer, men mange fattige sluttede sig til protesterne. Det var kun med nød og næppe at Revolutionsgarden og Basij-militsen formåede at undertrykke optøjerne.

\section{Strukturelle problemer}

I sammenligning med 2009, udgjorde december 2018-protesterne næppe nogen større trussel mod regimets overlevelse, men de viser samtidig tre strukturelle problemer i det iranske politiske system:

For det første er Den Islamiske Republiks herskende eliter ved at positionere sig for at øve indflydelse på arvefølgen efter Ayatollah Ali Khamenei. Eliterne kan lidt forsimplet inddeles i regimets to søjler: Teknokraterne anført af Rouhani og Revolutionsgarden, som beskytter regimet mod den hjemlige opposition og afskrækker eksterne fjender.

I deres indbyrdes rivalisering forsøger de også at mobilisere befolkningen for deres sag blandt andet ved at angribe hinandens økonomiske interesser. Rouhani forsøger at fravriste Revolutionsgarden dens økonomiske interesser (mere end en tredjedel af de børsnoterede virksomheder på Teherans Børs ejes af Revolutions- 
gardens mange finans- og kreditinstitutter, og gardens ingeniørkorps er samtidigt landets største entreprenørvirksomhed), mens Revolutionsgarden anklager Rouhani for at have svigtet de fattige og sågar for at have været med til at puste til protesternes ild i december 2018. I fald protesterne udvikler en effektiv ledelse, kan de spille på rivaliseringen mellem teknokraterne og Revolutionsgarden.

For det andet overstiger Den Islamiske Republiks regionale ambitioner landets begrænsede økonomiske formån. December måneds optøjer var præget af slagord imod Revolutionsgardens militære engagement i Syrien og Irak, og overalt råbte folk 'Hverken Gaza eller Lebanon, jeg ofrer mit liv for Iran' eller 'Lad Syrien være, tænk på os'!

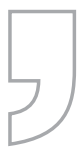

\section{Protesterne, som var en slags forløber for hvad der senere blev kendt som 'Det Arabiske Forår', skabte Irans 'Grønne Bevægelse', som kulminerede i demon- strationer i Teheran, hvor en million iranere gik på gaden imod valgsvindel.}

Iran finansierer sine regionale militære eventyr ved hjælp af indtægterne fra olieeksporten, som til gengæld er genstand for store udsving på grund af svingningerne i olieprisen.

Irans støtte til Bashar al-Assads regime i Syrien er et godt eksempel herpå. Teheran menes at understøtte Damaskus med mellem 15 til 20 mia. dollar. Den Islamiske Republiks årlige økonomiske støtte til Islamisk Hamas er begrænset til nogle hundreder mio. dollar, mens støtten til libanesisk Hizbollah anslås at være på ca. en mia. dollar. Organisationens generalsekretær anerkendte den iranske støtte i juni 2016 ved at påpege: "Hizbollahs budget, lønninger, mad, drikke og våben kommer alle fra Iran... Så længe Iran har penge, har vi også!"

Til sammenligning var Rouhanis budgetforslag til finansåret 2018/19 på blot 103 mia. Ifølge Centralbankens beregninger har det indeværende finansårs budget et underskud på over 5,3 mia. dollar, hvilket forklarer Rouhanis forsøg på at skære ned på subsidierne til benzinprisen i næste års budget.

Med andre ord, står Teheran over for det lidet misundelsesværdige valg mellem enten at sænke sine regionale ambitioner og mindske støtten til sine allierede for at brødføde sin egen befolkning eller lade befolkningen sulte i et forsøg på at sikre sin position som regional hegemon. På længere sigt bringer denne ubalance mellem storpolitiske ambitioner og hjemlige behov regimets overlevelse i fare.

For det tredje tyder en række tegn på, at den veluddannede middelklasse og de underprivilegerede kunne finde sammen. I kølvandet på fattigdomsoptøjerne er der opstået en kvindebevægelse imod den påtvungne islamiske hijab, som mobiliserer kvinderne i storbyerne. Adskilte udgør de, som forlanger brød, og de, som forlanger frihed - herunder friheden til ikke at lade sig dække af påtvungen hijab - næppe nogen større udfordring mod Den Islamiske Republik, men tilsammen udgør de en formidabel trussel mod regimets overlevelse.

Alt imens må regimets herskende eliter overveje, om de ønsker eller ser sig i stand til at enten at levere brød eller frihed. 


\title{
Anmeldelse: Nedrustnings- begrebets lange vej gennem folkeretten
}

\author{
Af Henrik Døcker
}

Dansk diplomat belyser de internationale nedrustningsbestræbelser i både et historisk og folkeretligt perspektiv - helt tilbage til de første forsøg på at etablere en international verdensorden baseret på fredelig konfliktløsning.

John Kierulf: Disarmament under international Law, DJØF Forlag, 276 sider.

Bestræbelser på globalt at begrænse rustningerne har ikke siden 1990'erne haft nogen fremtrædende plads i international sikkerhedspolitik, og forhandlinger om reduktion af atomvåbnene er gået i stå. Alligevel er det vigtigt, at der udgives en bog som John Kierulfs, der i sin engelske udgave er en à jour-føring af den dansksprogede Nedrustning i et folkeretligt perspektiv, der udkom i 2014. Som jurist og dansk diplomat har Kierulf i årevis beskæftiget sig med emnet, der her udfoldes i mange detaljer, men på en overskuelig måde.

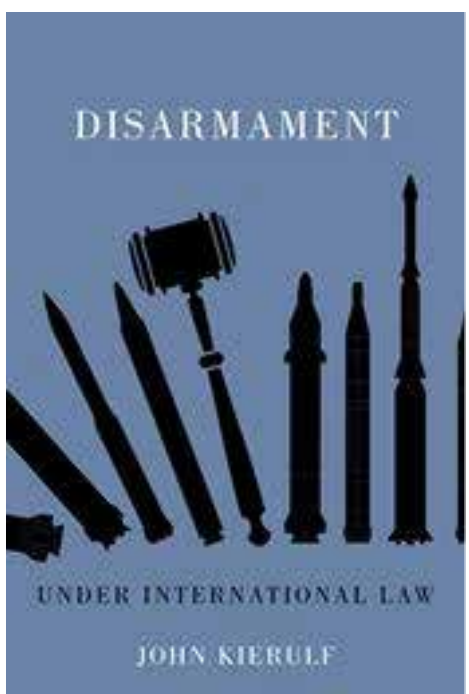

Kontrol med våben og forsøg på at reducere dem - eller rettere de farligste af dem - har været udfoldet i de sidste godt 100 år. Men det var først efter Anden Verdenskrig, at der kom rigtig skub i dem under indtryk af atombombesprængningerne over Hiroshima og Nagasaki. Med Kierulf international politik og ret i dansk dags- og tidskriftpresse. 
skal vi dog have forhistorien med. På en måde tog den moderne, eller, om man vil, nutidens folkeret sin begyndelse i 1899, da der på initiativ af Rusland indkaldtes til en såkaldt fredskonference i Haag med det formål at sikre freden gennem begrænsning af større våbenlagre, som datidens stormagter, særlig Tyskland, opbyggede. Her blev brug af dumdum-kugler og giftige gasser bl.a. forbudt.

På en anden Haag-fredskonference i 1907 vedtoges en række konventioner om krigsførelse, herunder det, der på dansk blev kendt som Haag-landkrigsreglementet. Heraf fremgik bl.a., at krigsførende (stater) ikke havde ubegrænset ret til at skade fjenden, idet gift eller forgiftede gasarter og brug af projektiler eller våben, som forårsagede unødvendige lidelser, blev forbudt.

Alt dette og meget mere kom til at indgå i de Geneve-konventioner, der i Røde Kors-regi kom til verden i 1949. Haag-konferencerne støbte så at sige fundamentet til det, der efter Anden Verdenskrig blev udviklet som den humanitære folkeret, et moderne udtryk for krigens folkeret.

Afbrudt af Første Verdenskrig kom nedrustningsforsøg først videre i Folkeforbundets regi, og da især i form af straffeforanstaltninger til krigens store tabermagt Tyskland. Begrænsninger, som dette land efter nazisternes magtovertagelse i 1933 lod hånt om, og som omverdenen trods Versailles-traktatens bestemmelser ikke greb ind overfor. Forinden lykkedes det internationalt gennem en såkaldt Geneve-protokol af 1925 at få forbudt kvælende, giftige gasarter og bakteriologiske krigsmidler, foranlediget af smertelige menneskelige tab og lidelser under verdenskrigen.

På det storpolitiske plan tiltrådte Frankrig, Tyskland og USA i 1929 den såkaldte Briand-Kelogg-pagt (opkaldt efter hen- holdsvis den franske og amerikanske udenrigsminister), der forsagede krig som sådan - et forsøg, der angiveligt (men det nævner Kierulff ikke) var ansporet af de europæiske magter for at få USA med i et slags sikkerhedssystem, eftersom amerikanerne ikke var blevet medlem af Folkeforbundet.

\section{Første anti-atomtraktat i FN-regi}

Med Kierulff ved hånden kan man notere sig, at Folkeforbundet i 1932 indkaldte til verdens første internationale nedrustningskonference, som imidlertid led skibbrud, da Tyskland forlod den - og siden også Folkeforbundet. Masseødelæggelsesvåben blev betegnelsen for ikke-konventionelle våben, der forårsager store, ukontrollable tab og ødelæggelser, første gang brugt af den spanske oprørsgeneral Francisco Francos tropper mod den baskiske by Guernica i den spanske borgerkrig i 1937.

I dag regnes atomvåben foruden biologiske og kemiske våben samt disses fremføringsmidler (missiler) for masseødelæggende. Ifølge bogen findes der i dag - spredt på ni lande - i alt 17.270 atomvåben i verden. Yderligere 30 lande formodes at have teknologisk kapacitet til at udvikle og fremstille atomvåben.

I FN's pagt nævnes ordene nedrustning og våbenkontrol kun i tre af dens i alt 111 artikler, men ved den første resolution, som FN's Generalforsamling vedtog i januar 1946, nedsattes en atomenergikommission.

Forfatteren minder om, at den danske atomfysiker Niels Bohr, der deltog i det store amerikanske Manhattan-projekt, som udviklede atombomben, $i$ et åbent brev til FN af 9. januar 1950 påpegede den fare, atomenergien frembød, hvis den blev brugt til militære formål. (Det kan tilføjes, at ordet menneskerettigheder også kun fore- 
kommer tre steder i FN's pagt. Antallet af emner og begreber, som stater og pressionsgrupper har ivret for medtagelse i pagten, har givetvis været overvældende. Anmelderens bemærkning).

Den vigtigste globale aftale til begrænsning af atomvåbnene er uden for enhver tvivl anti-atomspredningstraktaten af 1 . juli 1968, som trådte i kraft to år efter. Den er i dag tiltrådt af 191 stater, dvs. hele verden undtagen Indien, Israel og Pakistan foruden den unge stat Sydsudan. Nordkorea var oprindelig også bundet af traktaten, men i 1993 opsagde det den.

Der skelnes imidlertid mellem de (i forvejen) atomvåben-besiddende stater og så de, der ikke har disse våben. I førstnævnte kategori er Frankrig, Kina, Rusland, Storbritannien og USA - de er (tilfældigvis?) også permanente medlemmer af FN's sikkerhedsråd.

Forfatteren føjer til, at de teknologiske fremskridt har gjort det muligt at sikre atomvåbnenes fortsatte funktionsdygtighed uden at foretage atomprøvesprængninger. Ved computersimulation kan der endog udvikles nye former for atomvåben og afprøvning af dem - og ja, så kunne atomstaterne jo lige så godt tiltræde den traktat med forbud mod atomprøvesprængninger, som FN's Generalforsamling vedtog i 2015. 164 har allerede ratificeret den - et udtryk for at dette emne er godt på vej til at blive del af international sædvaneret, bemærker Kierulf.

\section{Fem tilfælde af atomkrigsfare}

Efter bogens udgivelse lykkedes det i sommeren 2017 på en FN-konference at få vedtaget verdens første atomforbudstraktat, som kun retter sig til de stater, der ikke i forvejen har atomvåben; de lover at afstå fra at afprøve, fremstille, erhverve, besidde eller oplagre atomvåben. Trakta- ten træder i kraft, når 50 stater har ratificeret den.

Kierulf har dog omhyggelig redegjort for traktaten i sin bog, hvoraf det fremgår, at den definerer 'atomsikkerhed' som dette, at staterne i forbindelse med atomvåben forebygger og afslører tyveri af dem, deres brug til sabotage, ulovlige eller andre ondsindede handlinger. Man fristes til at sige, at papiret er tålmodigt, og at løfterne er mange - uden at udsigten til den store 'bremseværdi' er særlig let at få øje på. Kierulf finder imidlertid, at konventionen udfylder farlige mangler i det, som han kalder 'det nuværende atomregime', idet den kan medvirke til at forebygge atomterrorisme.

Forfatteren gør opmærksom på, at verden har været tæt på atomkrig mindst fem gange siden atomvåbnenes fremkomst:

(1) Ved Cuba-krisen i 1962, da kaptajnen på en atombevæbnet sovjetisk ubåd var på nippet til at affyre en atomtorpedo, men blev bremset af sin overordnede, kommandøren for den del af sovjetflåden, som befandt sig i farvandet omkring Cuba.

(2) Da det ved en computerfejl i en amerikansk kommandocentral - som heldigvis blev opdaget - i 1980 blev meldt, at et sovjetisk atomangreb var blevet iværksat.

(3) Da en sovjetisk officer i et missil-kontrolcenter i 1983 modtog signal om, at et amerikansk missilangreb var blevet iværksat, men valgte at afstå fra et gengældelsesangreb i sidste øjeblik.

(4) Da NATO mindre end to måneder senere gennemførte en større øvelse, som Sovjetunionens politiske og militære ledelse først troede var indledningen til et atomangreb.

(5) Da en amerikansk raket med forskningsformål blev affyret fra en norsk ø nær den sovjetiske kyst. Selv om russerne var blevet adviseret, så var meldingen ikke nået frem til Sovjetsunionens såkaldte 'ear- 
ly warning'- system, men en reaktion herpå blev så også her afværget i sidste sekund.

Under gennemgang af atomfrie zoner i verden konstaterer forfatteren, at en sådan ikke har kunnet oprettes i Mellemøsten på grund af Israels de facto-besiddelse af atomvåben. Nok er Norden også (de facto) en atomfri zone, men formelt skal den ikke være det, idet en sådan status, som forfatteren ser det, ville have fjernet fleksibilitet $\mathrm{i}$ den sikkerhedspolitiske handlefrihed, som Danmark siden 1957 har nydt godt af.

Fravær af denne ville have udelukket os fra at blive forsvaret med atomvåben af andre nationer. $O g$ sådan frembyder bogen i det hele taget noget nær en guldgrube af viden om biologiske, kemiske og radiologiske våben, håndvåben, lette våben, antipersonelminer og klyngebomber med meget mere. Om droner, der også kaldes 'ubemandede luftfartøjer', oplyses det, at der i dag findes 50 forskellige typer, som produceres i 50 forskellige lande.

\section{Mistillid og kontrolvanskeligheder}

Hvis nogen skulle have haft opfattelsen af, at NATOs forhold til Rusland inden den nuværende Ukraine/Krim-krise var bare nogenlunde tilfredsstillende, kan de hos Kierulf hente stof til eftertanke.

Siden 2007 har Rusland således ikke udvekslet oplysninger om antal, placeringer og flytninger af konventionelle våben og udstyr, således som ellers forudsat i traktaten om konventionelle væbnede styrker i Europa (CFE). Det er blevet begrundet med, at NATO-landene ikke har ratificeret en tilpasningsaftale under CFE, hvad disse magter igen begrundede med manglende russisk troppetilbagetrækning fra Moldova (nærmere bestemt udbryderrepublikken Transnistrien) og styrkereduk- tioner i Georgien. Som forfatteren anfører, er Ruslands suspension folkeretsstridig, da CFE-traktaten ikke åbner mulighed for en sådan undtagelse.

Det er umuligt blot tilnærmelsesvis at komme ind på alle de emner, som bogen indeholder: Våbenhandel, eksportkontrol, brug af de internationale domstole, minerydning og meget andet. Kierulf minder om et Lenin-citat, som USA's tidligere præsident Ronald Reagan yndede, og som på engelsk lyder 'Trust but verify'. (Den danske version lyder almindeligvis 'Tillid er godt, kontrol er bedre').

Essensen er, at alle disse rustningstraktater (som andre internationale aftaler) bør kontrolleres, det vil sige efterprøves, for så vidt angår deres efterlevelse. I diplomatfagsproget: Verificeres. Man taler også om at monitorere. Og, ja, der er masser af problemer med dette, måske tydeligst eksemplificeret ved de vanskeligheder inspektører fra IAEA (Det Internationale Atomenergiagentur) har mødt og har været konfronteret med i Iran. Tidligere var det Irak under Saddam Hussein.

I den store informationsmængde serveres læseren også for overskuelige facts om Danmarks nedrustningspolitik, herunder indsatsen for at begrænse spredningen af atomvåben. Et oversigtsværk, holdt i mundret sprog, som på det varmeste må anbefales alle med interesse for ét af FN's nøgleområder: nedrustningsbestræbelserne.

Denne bog har ud over sine mange detaljeoplysninger om atomvåben som sådan og særlig de traktater og andre internationale vedtagelser om dem også en række nyttige personlige kommentarer efter hvert af de 14 kapitler. De styrker læserens refleksion over de mange informationer. 


\section{Bognoter}

\section{Af Brita Vibeke Andersen}

Deneen, Patrick: Why Liberalism Failed. Yale University Press, 2018, 224 s.

Af de tre dominerende ideologier fra det 20. århundrede: fascisme, kommunisme og liberalisme er kun liberalismen tilbage. Det har betydet, at de, der går ind for liberalismen, har en tendens til at glemme, at det er en ideologi, og tror, at det er et naturligt sidste skridt i den politiske evolution, skriver politologen og lektor ved Notre Dame University Patrick Deen i sine bog Why Liberalism Failed. Patrick Deen argumenterer, at liberalismen bygger sit ideologiske udgangspunkt på indbyggede modsætninger: på den ene side lige rettigheder for alle samtidig med at liberalismen tillader og skaber materiel ulighed; liberalismen er på den ene side funderet på individets autonomi, men har på den anden side med været med til at frembringe et system med stærke statslige bureaukratier. I sin bog advarer Patrick Deen om, at de kræfter, som nu er blevet en dominerende del af vores politiske kultur ikke er overfladiske og forbigående, men er indbyggede karaktertræk i en ideologi, hvis succes skaber sin egen undergang.

Gessen, Masha: The future is history: How Totalitarianism reclaimed Russia. London Granta Books, 2017, 515 s.
Journalist og forfatter Masha Gessen har skrevet flere Putin-kritiske bøger og artikler. Senest bogen The man without a face: the unlikely rise of Valdimir Putin. I The future is history giver hun en mere overordnet analyse af, hvad der er sket i Rusland efter 1984 frem til 2015, og hvordan Rusland forsøgte at håndtere de ekstraordinære begivenheder, som fulgte i kølvandet på henholdsvis præsidenterne Gorbatjov, Jeltsin og Putin. Bogen udgør et slags essay over russernes forhold til magt. Det er samtidig en slags selvbiografi, hvor Masha Gessen rekonstruerer via individuelle personskæbner og portrætter Ruslands nyere historie. Man kan blandt andet læse om den likviderede oppositionspolitiker Boris Nemtsovs datter Zhanna Netsova eller grundlæggeren af det uafhængige opinions Institut Levada Center.

\section{Grigas, Agnia: The New Geopolitics of Natural Gas. Harvard University Press, 2017, 416 s.}

Agnia Grigas hovedhypoteser i bogen The New Geopolitics of Natural Gas er, at vi står over for en energirevolution ført an af USA. USA er nu verdens største naturgaseksportør og arbejder aggressivt på at udvide sit marked for flydende naturgas og 
sikre sig en supermagts position på energiområdet. Det er en udvikling som kan have stor indflydelse på hele den internationale verdensorden, hvor især Rusland står til at miste indflydelse. Agnia Grigas borer i bogen dybt ned i dagens gasmarked for at afdække de kræfter og tendenser, som påvirker den globale geopolitik på gasområdet.

Guérot, Ulrike og Elisabeth Donat (red.): Was ist los mit Frankreich? Von politischer Zersetzung zu socialer Neuordnung. Krems Publication Series on European Democracy (KPSED), Band 1, 2017, 256 s. Emmanuel Macron er ny præsident $\mathrm{i}$ Frankrig, men hvordan går det egentlig i Frankrig. Er landet på vej mod en epokegørende omorganisering måske ligefrem en 'revolution'. Og hvad betyder det for Tyskland og for Europa. I Was ist los mit Frankreich? giver sociologer, politologer, men også aktivister fra det franske civilsamfund og unge franskmænd fra vidt forskellige synsvinkler deres bud på et svar.

Kepel, Gilles: Terror in France: The rise of jihad in the West. Princeton University press, 2017, $240 \mathrm{~s}$.

Gilles Kepels Terror In France undersøger Frankrigs interne politiske og sociale dynamikker samt de strategier som de regerende eliter har forsøgt sig med siden præsident Sarkozy. Kepel beskriver og dokumenterer, at modsat det gængse billeder lever franske muslimer ikke $i$ et politisk og isoleret parallelunivers. Franske muslimer har historisk været aktive deltagere i nationens politiske liv. Et af Kepels hovedargumenter er, at opblomstringen af jihad grupper skal ses i sammenhæng med øget støtte til andre anti-establishment partier og grupper generelt set.
Krastev, Ivan: Efter Europa. Europæiske ideer. Informations Forlag 2017, 121 s. Efter Europa handler om Europas fremtid og muligheden for unionens opløsning. Den højrenationalistiske populisme spreder sig, briterne er på vej ud, og de mere end 1,3 millioner migranter fra Mellemøsten, Nordafrika, og Sydasien har medført en politisk destabilisering på nationalt niveau over hele kontinentet. Det er ikke blot en populistisk revolte imod det etablerede system, der hjemsøger Europa, men vælgernes oprør mod de meritokratiske eliter. Fra Barcelona til Budapest frygter ængstelige flertal fremmede mindretal. De er overbevist om, at krisen skyldes en sammensværgelse af kosmopolitisk orienterede eliter og stammeorienterede indvandrere. Europas udfordring i dag er at imødekomme flertallets bekymringer og samtidig dæmme op for de reaktionære impulser, der ledsager dem - en udfordring, som Krastev forbereder os på.

\section{Levitsky, Steven og Daniel Ziblatt: How}

Democracies Die: What history tells us about our future. Crown, 2018, 320 s. To professorer fra Harvard har med udgangspunkt i deres ekspertise i populisme og autokratisk styre i det 1900. og 2000. århundredes Europa og Latinamerika beskrevet, hvad der sker i overgangen fra demokrati til autokrati. Bogens formål er at gøre amerikanerne opmærksom på, at deres 'checks and balances' til trods, så er det amerikanske demokrati ikke immunt over for de sygdomme, som tidligere har gjort det af med andre demokratier. Professorerne mener, at præsident Donald Trump allerede har overskredet grænsen for hvad der kendetegner en populistisk leder til en potentiel autokratisk ledertype. De beskriver fire indikatorer, som kendetegner en autokratisk leders opførsel, så læseren selv 
kan beslutte, hvorvidt Trump er en autokrat.

Nedergaard, Peter: Klimapolitik - et samfundsperspektiv. Forlaget Columbus, 3. udgave 2017, $141 \mathrm{~s}$.

I sin nye udgave af Klimapolitik giver Peter Nedergaard en udførlig introduktion til klimapolitikken som et politisk fænomen. Bogen beskæftiger sig bl.a. med følgende spørgsmål: Hvad er baggrunden for, at klimapolitikken er blevet så vigtigt et emne? Hvad består de klimapolitiske problemer i? Hvordan har det internationale klimapolitiske samarbejde udviklet sig? Hvorfor er det tilsyneladende så svært at finde internationale løsninger på de klimapolitiske problemer? Hvad er de enkelte lande eller landegruppers holdninger til, hvad klimapolitik er?

\section{Serinci, Deniz B.: Slave i Islamisk Stat.} Ghaliyas historie. Gyldendal 2017, 240 s. Journalist, forfatter og foredragsholder Deniz B. Serincis bog Slave i Islamisk Stat er historien om en familie og et folk, der spredes for alle vinde under pres fra en af vor tids mest formørkede ideologier. Hovedpersonen Ghaliya er 27 år, da Is- lamisk Stat overtager byen i det nordlige Irak, hvor hun bor. Hun tilhører den religiøse gruppe, ezidierne, som de militante islamister er særligt ude efter. Ghaliya har det meste af sit liv haft ansvar for sine fire yngre søskende, men Ghaliya og søsteren Markaz mister kontakten til deres tre brødre under en kaotisk flugt. Islamisk Stat skiller mændene fra kvinderne, når de tager fanger. Ezidi-mændene likvideres, mens kvinder og børn udsættes for påtvungen konvertering, religiøs indoktrinering, voldtægter og slaveri. Ghaliya og hendes søster tilbringer 285 dage i fangenskab hos flere forskellige IS-krigere, inden det lykkes dem at stikke af.

Souza, Pete: Obama i nærbillede. Otte år i Det Hvide Hus. Gyldendal 2018, 352 s. Nærportræt af de otte år, Barack Obama var amerikansk præsident - fotograferet af en af USA's førende fotojournalister, Pete Souza, som var Obamas officielle fotograf. Her er både ikoniske, kendte fotos og en lang række situationer bag facaden. Med forord af Obama selv. 


\section{Om Selskabet}

DET UDENRIGSPOLITISKE SELSKAB

Det Udenrigspolitiske Selskab er en privat, almennyttig forening. Den er stiftet i 1946 med det formål at fremme kendskabet til og højne interessen for udenrigspolitiske spørgsmål i Danmark. Selskabet er uafhængigt af såvel det offentlige og de politiske partier som af erhvervsog organisationsinteresser. Det tager ikke stilling til politiske spørgsmål, men fungerer udelukkende som formidler af information, debat og kontakter.

Der er i øjeblikket omkring 1.000 personlige medlemmer. Yderligere 150 personer er medlemmer via et halvt hundrede firmaer og institutioner. Selskabet har en ungdomsafdeling U35 med ca. 200 medlemmer.

\section{Det Udenrigspolitiske Selskab holder} regelmæssigt møder, konferencer og andre former for arrangementer med fremtrædende danske og udenlandske talere. Arrangementerne, der er forbeholdt Selskabets medlemmer og særligt inviterede gæster, holdes som hovedregel i det centrale København.

Er man interesseret $\mathrm{i}$ at blive medlem, så send venligst en mail med en kort præsentation til udenrigs@udenrigs.dk eller gå ind på www.udenrigs.dk

\section{PROTEKTOR}

Hans Kongelige Højhed Kronprins Frederik

\section{AERESMEDLEM}

Uffe Ellemann-Jensen · tidl. udenrigsminister

\section{RÅDET}

Lykke Friis (bestyrelsens formand)* Merete Ahnfeldt-Mollerup

Christian Friis Bach

Jesper Berg*

Victoria Bernstorff

Ingelise Bogason

Henrik Breitenbauch

Camilla Brückner

Uffe Ellemann-Jensen

Ulrik Federspiel*

Troels Frøling

Connie Hedegaard

Michael Jarlner*

Anne Knudsen

Suzanne B. Danneskiold Lassen*

Lukas A. Lausen*

Anna Libak*

Mogens Lykketoft

Siegfried Matlok

Ida Nicolaisen

Klaus Carsten Pedersen

Torben Möger Pedersen*

Nils Chr. Wang

*Indgår også i Det Udenrigspolitiske Selskabs bestyrelse 


\section{Om Udenrigs}

UDENRIGS ER UDKOMMET SIDEN 1946

\section{REDAKTION}

Charlotte Flindt Pedersen [ansvarshavende]

Brita Vibeke Andersen

\section{REDAKTIONSKOMITÉ}

Louise Riis Andersen

Lene Frøslev

Martin Marcussen

Marcus Rubin

Mette Skak

Martin Selsøe Sørensen

Uffe Østergård

\section{DESIGN OG TRYK}

Design: Kiberg \& Gormsen

Trykt hos GSB Grafisk

Udenrigs udkommer tre gange årligt.

Redaktionen afsluttet 15.02.2018

Abonnementspris 250 kr., institutioner 400 kr.
UDGIVER

Det Udenrigspolitiske Selskab

Amaliegade 40 A, 1256 København K.

+45331488 86

udenrigs@udenrigs.dk

www.udenrigs.dk

\section{DIREKTION}

Charlotte Flindt Pedersen

ISSN 1395-3818 
